\title{
Surficial mapping and kinematic modeling of the St. Clair Thrust Fault, Monroe County, West Virginia
}

Jason M. Sturms

West Virginia University

Follow this and additional works at: https://researchrepository.wvu.edu/etd

\section{Recommended Citation}

Sturms, Jason M., "Surficial mapping and kinematic modeling of the St. Clair Thrust Fault, Monroe County, West Virginia" (2008). Graduate Theses, Dissertations, and Problem Reports. 2641.

https://researchrepository.wvu.edu/etd/2641

This Thesis is protected by copyright and/or related rights. It has been brought to you by the The Research Repository @ WVU with permission from the rights-holder(s). You are free to use this Thesis in any way that is permitted by the copyright and related rights legislation that applies to your use. For other uses you must obtain permission from the rights-holder(s) directly, unless additional rights are indicated by a Creative Commons license in the record and/ or on the work itself. This Thesis has been accepted for inclusion in WVU Graduate Theses, Dissertations, and Problem Reports collection by an authorized administrator of The Research Repository @ WVU. For more information, please contact researchrepository@mail.wvu.edu. 


\title{
Surficial Mapping and Kinematic Modeling of the St. Clair Thrust Fault, Monroe County, West Virginia
}

\author{
Jason M. Sturms \\ Thesis submitted to the \\ Eberly College of Arts and Sciences \\ at West Virginia University \\ in partial fulfillment of the requirements \\ for the degree of \\ Master of Science \\ in \\ Geology \\ Committee Members: \\ Jaime Toro, Ph.D., Chair \\ Robert Behling, Ph.D. \\ Dave Oldham, Ph.D. \\ Department of Geology and Geography \\ Morgantown, West Virginia \\ 2008
}

Keywords: St. Clair, Monroe County, Trishear, Fault Propagation 


\section{Abstract \\ Surficial Mapping and Kinematic Modeling of the St. Clair Thrust Fault, Monroe County, West Virginia}

\section{Jason M. Sturms}

Near the Allegheny Structural boundary between the Appalachian Plateau and the Valley and Ridge Province of the West Virginian Appalachians lie four major thrust faults: the Pulaski, Saltville, Narrows, and the St. Clair all of which are associated with the Alleghenian Orogeny. Of these major thrusts, the St. Clair thrust fault represents the boundary of the Allegheny Structural Front and is one of the few major thrust faults that are exposed at the surface in the Appalachians of West Virginia.

The St. Clair thrust fault represents an example of fault-propagation folding. Within fault-propagation folding, trishear deformation and fault-bend folding can be linked to deformation. Kinematic modeling was conducted using Midland Valley's 2DMove software package to recreate the geometry of the fault and its associated fold. Modeling software was also used to determine the effects of individual parameters within trishear deformation. The parameters examined include the propagation-to-slip ratio, trishear apex angle, trishear angle, angular shear, and the number of trishear zones. Of these parameters, the propagation-to-slip ratio has the most impact on the geometry of the footwall fold. The propagation-to-slip ratio determines how much the fault propagates through the strata and also dictates what type of fold develops. A P:S ratio that is zero results in the formation of a detachment fold, a small P:S ratio results in a trishear faultpropagation fold, and a large P:S ratio results in the development of a fault-bend fold.

Through surficial mapping and kinematic modeling, it has been concluded that the St. Clair thrust fault formed in two steps involving fault-propagation folding. The overturned syncline in the footwall, the Glen Lyn Syncline, was formed by trishear deformation, with a propagation-to-slip ratio of approximately 0.25 , as the fault slowly propagated through the strata. Then, the fault broke through to the surface due to an increase in the P:S ratio and a second mode of deformation occurred, fault-bend folding. This combination of trishear deformation and fault-bend folding created the present-day geometry of the St. Clair thrust fault and its associated structures.

By recreating the sequential cross-sections, it was possible to determine the amount of displacement needed for each cross-section. The southwestern most crosssection was modeled and a minimum displacement value of approximately 2300 meters was needed. Erosion has removed the hanging wall cut-off; therefore the total displacement is not constrained.

Two additional cross-sections to the northeast show evidence of an anticline in the hanging wall. The values of deformation in these cross-sections are more representative of the actual amount of displacement needed. Displacement values decreased from 7500 meters to 6700 meters toward the northeast, or by about $10 \%$. 


\section{Acknowledgements}

I would first like to thank the United States Geological Survey EDMAP Program for their generous funding of this thesis. I would like to express my gratitude to the family of Charlie Coffindaffer for providing monetary support. I would also like to thank the West Virginia State GIS Technical Center for providing base maps and other data that I have used in the making of the geologic map.

I would like to express thanks for my committee members, Jaime Toro, Bob Behling, and Dave Oldham, who deserve numerous thanks for their support and patience. There are several other individuals who have greatly impacted my graduate studies: Dick Smosna and all of the other professors within the geology department.

Finally, I would like to thank my parents, Bob and Susan Hopkins and Jim and Jeannie Sturms for their support. I am also indebted to my loving wife and field assistant, Kathryn, for her support and for putting up with me through college. Without these people in my life, I am not sure I could have come this far. 
This thesis has been dedicated in the memory of my grandfather, D.E. Shrewsbury:

This is for you 


\section{Table of Contents}

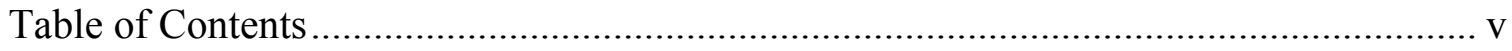

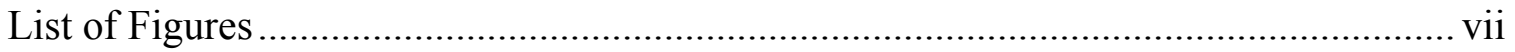

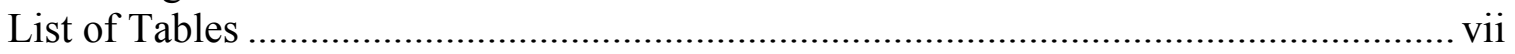

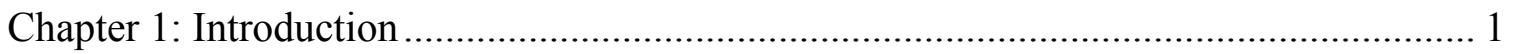

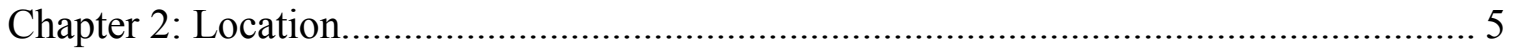

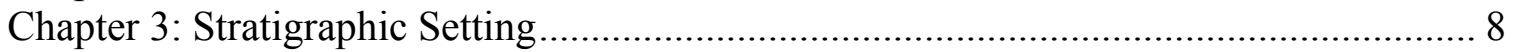

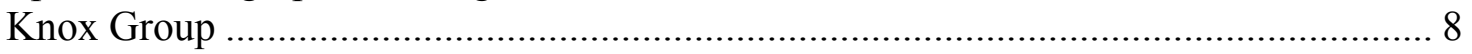

Middle Ordovician Limestone ........................................................................... 9

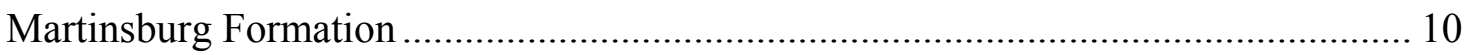

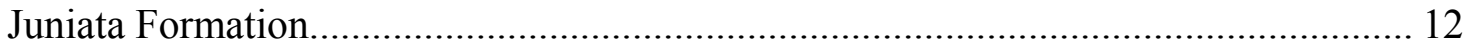

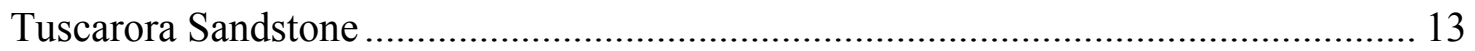

Rose Hill Formation............................................................................................. 14

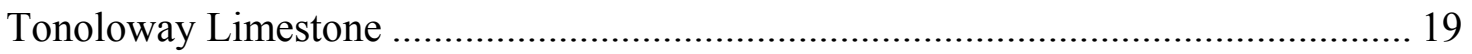

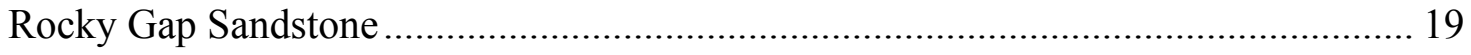

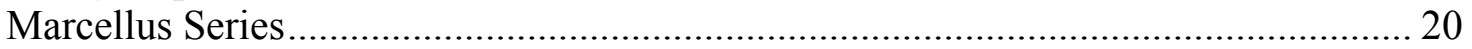

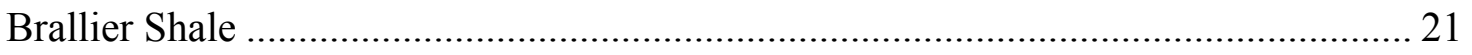

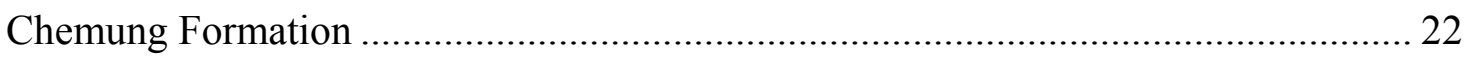

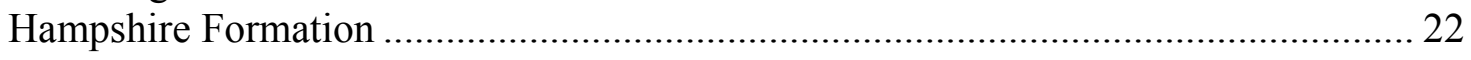

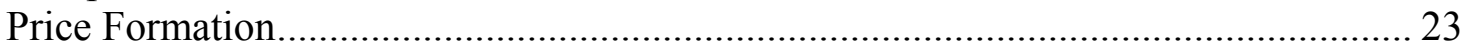

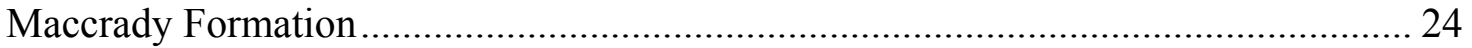

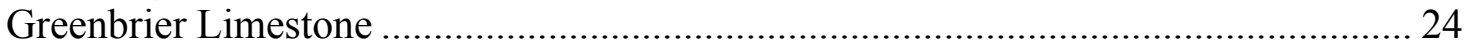

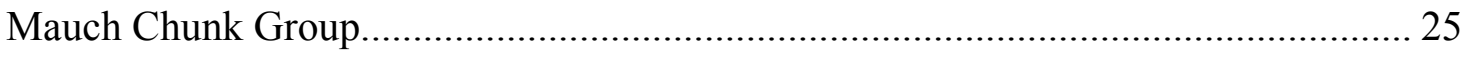

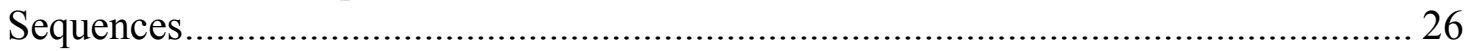

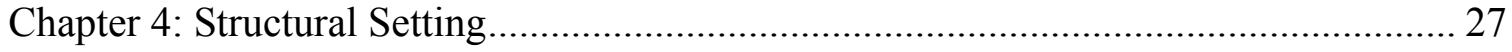

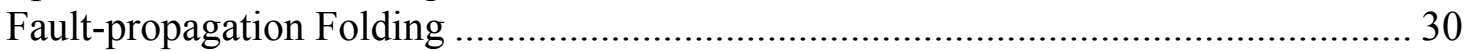

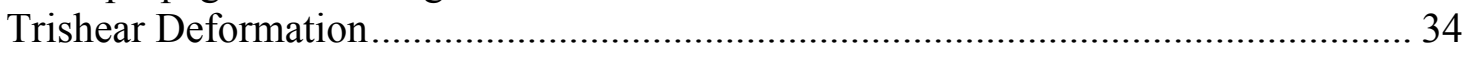

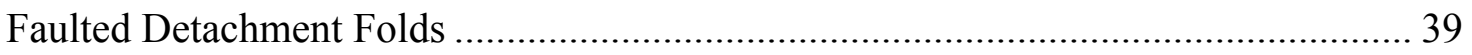

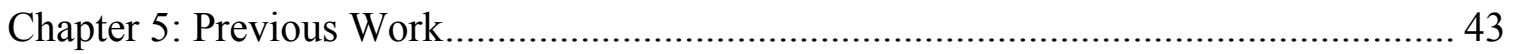

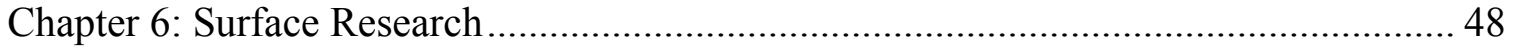

Background Information...................................................................................... 48

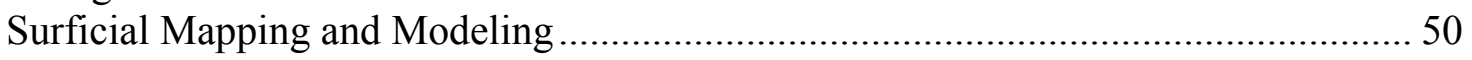

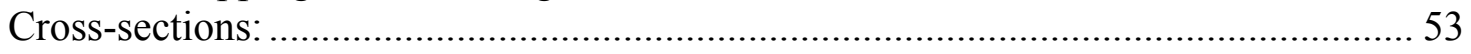

Chapter 7: Interpretations from Computer Modeling .............................................. 56

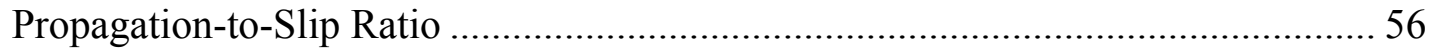

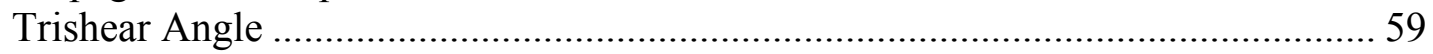

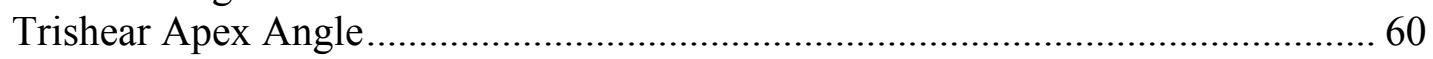

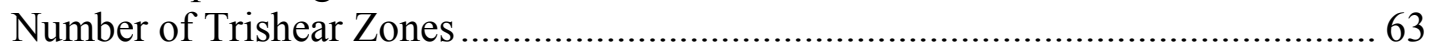

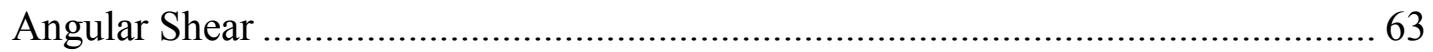

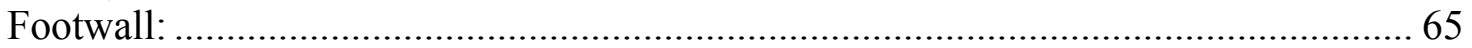

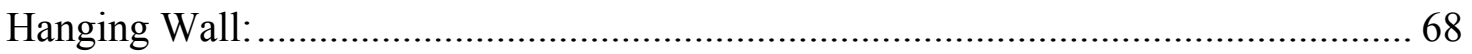

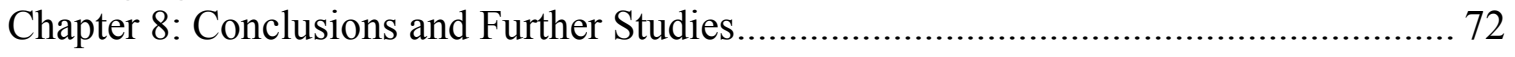

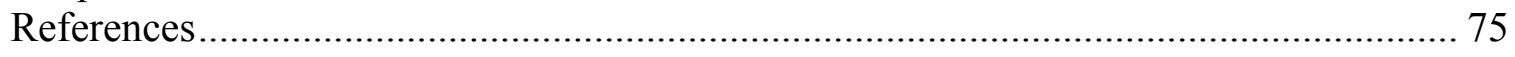

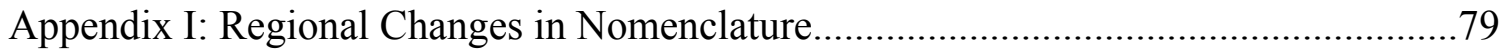

Appendix II: CMYK Values used for geologic mapping .......................................... 83 
Appendix III: Regional Changes in Nomenclature... 


\section{List of Figures}

Figure 1: Regional map showing location of study area............................

Figure 2: Geologic map showing USGS Quadrangle names and study area...............4

Figure 3: Regional map of St. Clair fault system .................................. 7

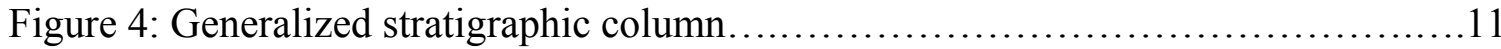

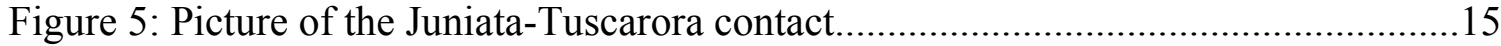

Figure 6: Picture of the Tuscarora Sandstone.................................... 15

Figure 7: Picture of the Rose Hill Formation...................................... 17

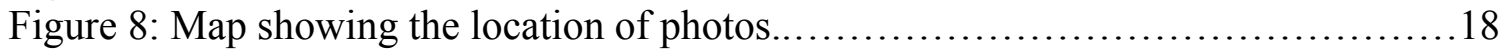

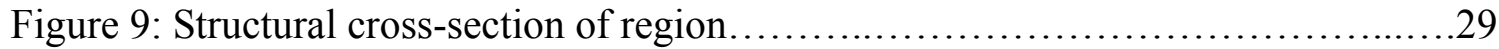

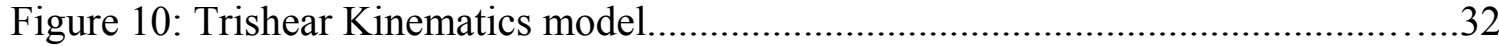

Figure 11: Evolution of a fault-propagation fold.................................... 33

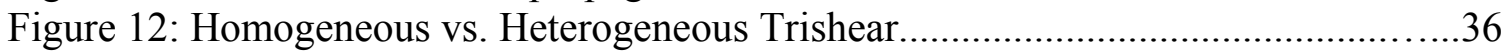

Figure 13: Strain ellipses along a fault in Trishear................................ 37

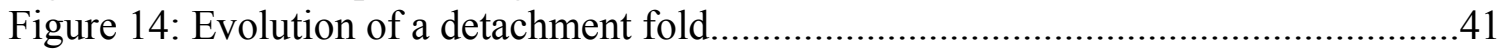

Figure 15: Map of the southern and central Appalachians..........................47

Figure 16: Sequential cross-sections........................................47

Figure 17: 2DMove flow chart...............................................49

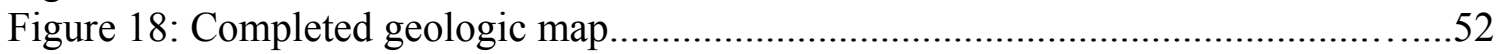

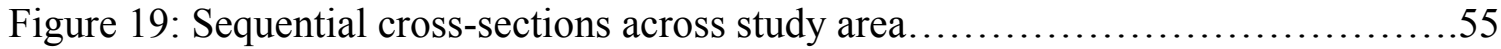

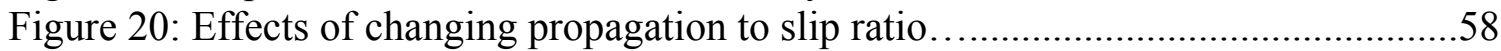

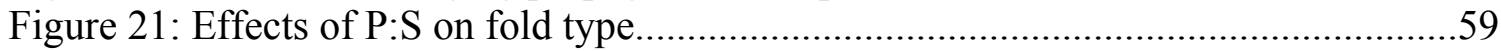

Figure 22: Effects of changing the trishear angle................................61

Figure 23: Effects of changing the Trishear apex angle............................62

Figure 24: Diagram showing the number of Trishear zones in a model.................63

Figure 25: Effects of inducing angular shear.....................................64

Figure 26: Beginning steps of kinematic model........................................................66

Figure 27: Footwall modeling of cross-section B-B' and C-C' ...................................... 70

Figure 28: Evolution of modeled cross-section........................................................... 71

\section{List of Tables}

Table 1: Comparison of fault-related fold styles. 


\section{Chapter 1: Introduction}

The St. Clair fault represents the boundary of the Allegheny Structural Front, as well as the approximate boundary between the central and southern Appalachians (Dean and Kulander, 1988), and is one of the few major thrust faults that are exposed at the surface in the Appalachians of West Virginia (Figures 1 and 3). The trace of the St. Clair fault ends just across the West Virginia-Virginia state line in Alleghany County, Virginia, but the northeastern extension of this same line of structural discontinuity, the Covington Lineament, extends into the Valley and Ridge of Virginia and possibly into the Shenandoah Valley (Dean, Kulander, and Skinner, 1988). The St. Clair thrust fault terminates within the core of the Wills Mountain Anticline at the junction of the southern and central Appalachians (Spraggins and Dunne, 2002).

As noted by Gustafson (1982), the hanging wall of the St. Clair fault is comprised of the Upper Cambrian Knox Dolomite through the Lower Mississippian Sandstones of the Price Formation (also known as the Pocono Formation). Also, the St. Clair fault represents a type of folding, known as a fault-propagation fold, which refers to an asymmetrical fold with one steep or overturned limb adjacent to a thrust fault (Figure 9) (Suppe and Medwedeff, 1984).

Theoretically, as the St. Clair fault dies to the northeast, the fault throw should decrease as we move from the southwest towards the northeast. I have tested this hypothesis by creating a geologic map and sequential cross-sections and by using kinematic modeling software, such as Midland Valley’s 2DMove. I have also attempted to show how the strain distribution within the trishear triangle zone could be related to fracture density, which could be useful for predicting the location of possible targets for 
natural gas production. This has been done in conjunction with Reed Johnsons' master's thesis "Surface and Subsurface Fracture Systems with Associated Natural Gas Production in the Lower Mississippian, Upper Price Formation, Southern West Virginia.” Most importantly, I have evaluated the kinematic development of the structures that are associated with the St. Clair fault. 


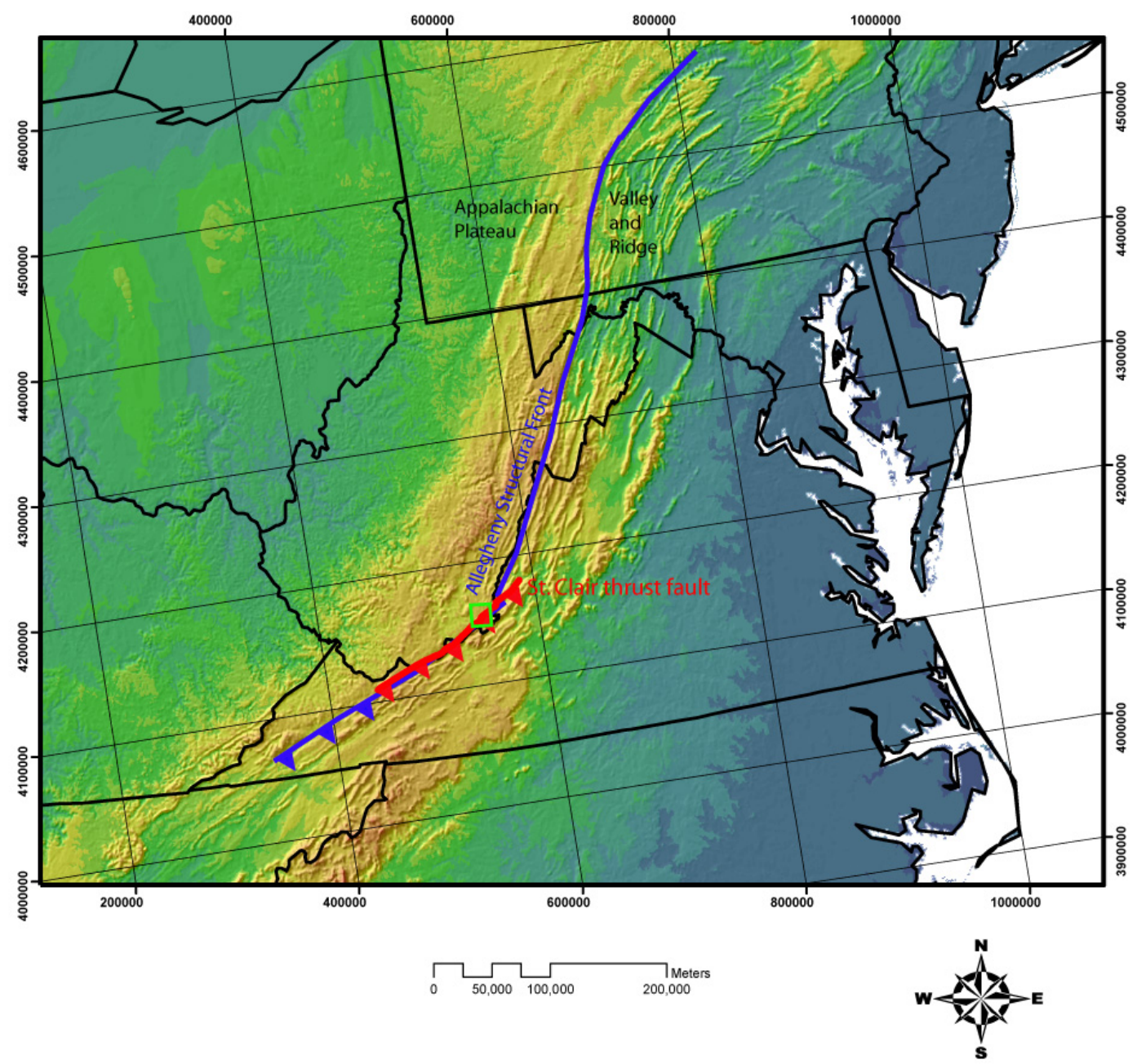

Figure 1: Map showing shaded relief and the location of the study area, indicated as the green box, also shown in Figure 2. Approximate locations of the Appalachian Plateau and Valley and Ridge Provinces are shown. The boundary between the two provinces, marked as a blue line, represents the Allegheny Structural Front. Coordinate system is UTM Zone 17. 
Formation Name

Mg Greenbrier

Mmc Maccrady

Mp Price

Dch Chemung

Db Brallier

Dm Marcellus

Drg Rocky Gap

Srh Rose Hill

St Tuscarora

Oj Juniata

Om Martinsburg

Omls Middle Ordovician Limestone

$\mathrm{Ob}$ Beekmantown

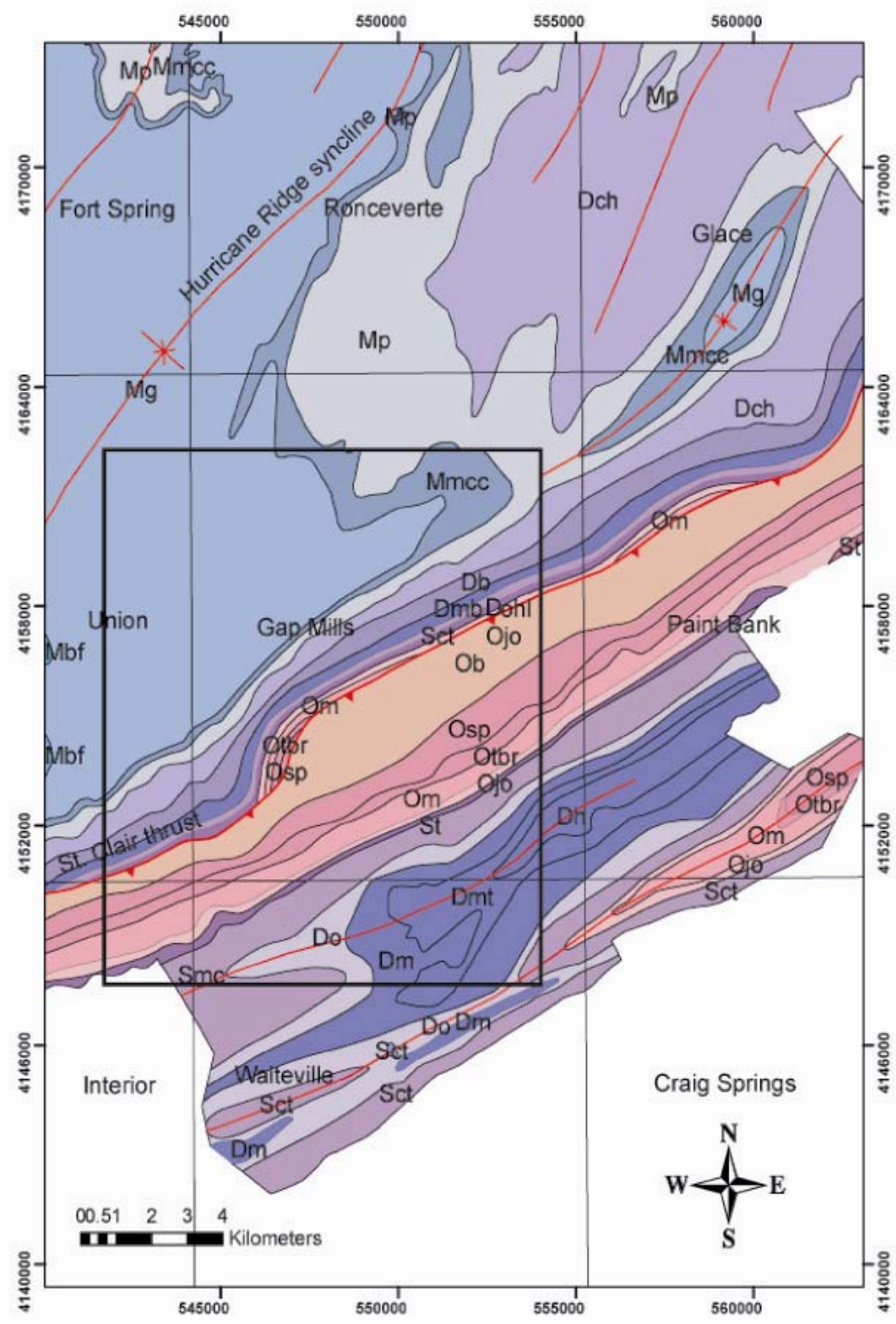

Figure 2: Geological map of the study area showing general geology, corresponding USGS Quadrangle names, faults, folds, and approximate study area (shown by black box). Coordinates are UTM Zone 17 (Modified from Cardwell, et al., 1968). 


\section{Chapter 2: Location}

The St. Clair fault, which is the northern segment of a $600 \mathrm{~km}$ long fault system, strikes in a northeasterly fashion through Russell, Tazewell and Giles Counties in Virginia, Mercer and Monroe Counties in West Virginia and Alleghany County in Virginia (Figure 3) (Butts 1940 and Gustafson 1982). The St. Clair fault, which is located in the northern end of the southern Appalachians, has been traced from its northern terminus in the core of an anticline in Allegheny County, Va. southwestward to the Clinchport and related faults of southwestern Virginia and Tennessee (McDowell and Schultz, 1989). It is in Russell County, Virginia where the St. Clair fault splits into two separate faults, the Russell Fork fault and the Honaker Thrust fault (Figure 3). The St. Clair fault is extremely well exposed on U.S. Highway 460 south of Rich Creek Va. and near Glen Lyn, Va. (McDowell and Schultz, 1989).

The area that has been mapped is located in Monroe County, WV, and covers the Gap Mills, Union, Waiteville, and Interior Quadrangles (Figure 2). Within the study area, elevation ranges from 2000 feet above sea-level just south of the town of Union, WV., to an elevation of 3900 feet along Peter's Mountain. The total vertical relief between the highest and lowest point within the study area is 1900 feet. There are several access roads that cut across the study area. The main access road is Zenith Road (CR 29), which transects the study area from east to west. Other roads of importance are Turkey Creek Road (CR 13/3), Gates Road, WV Route 3, Waiteville Road (CR 15), WV Route 219, and Crowder Road (CR 20). Turkey Creek Road cuts across the study area from Zenith Road to Gates Road. This is one of the more important roads in the study area, as it cuts across the St. Clair thrust fault just north of the town of Crimson Springs. Gates Road, WV Route 3, and WV Route 219 provide access to outcrops of the 
Greenbrier Limestone and the Mauch Chunk Group. Waiteville Road and Crowder Road are important access roads, as they transect Peter's Mountain, providing a look at strata ranging from the Late Cambrian - Early Ordovician Knox Group to the Devonian Marcellus Series. Finally, the Allegheny Trail provides foot access trending along the ridge of Peter's Mountain (Figure 8). 


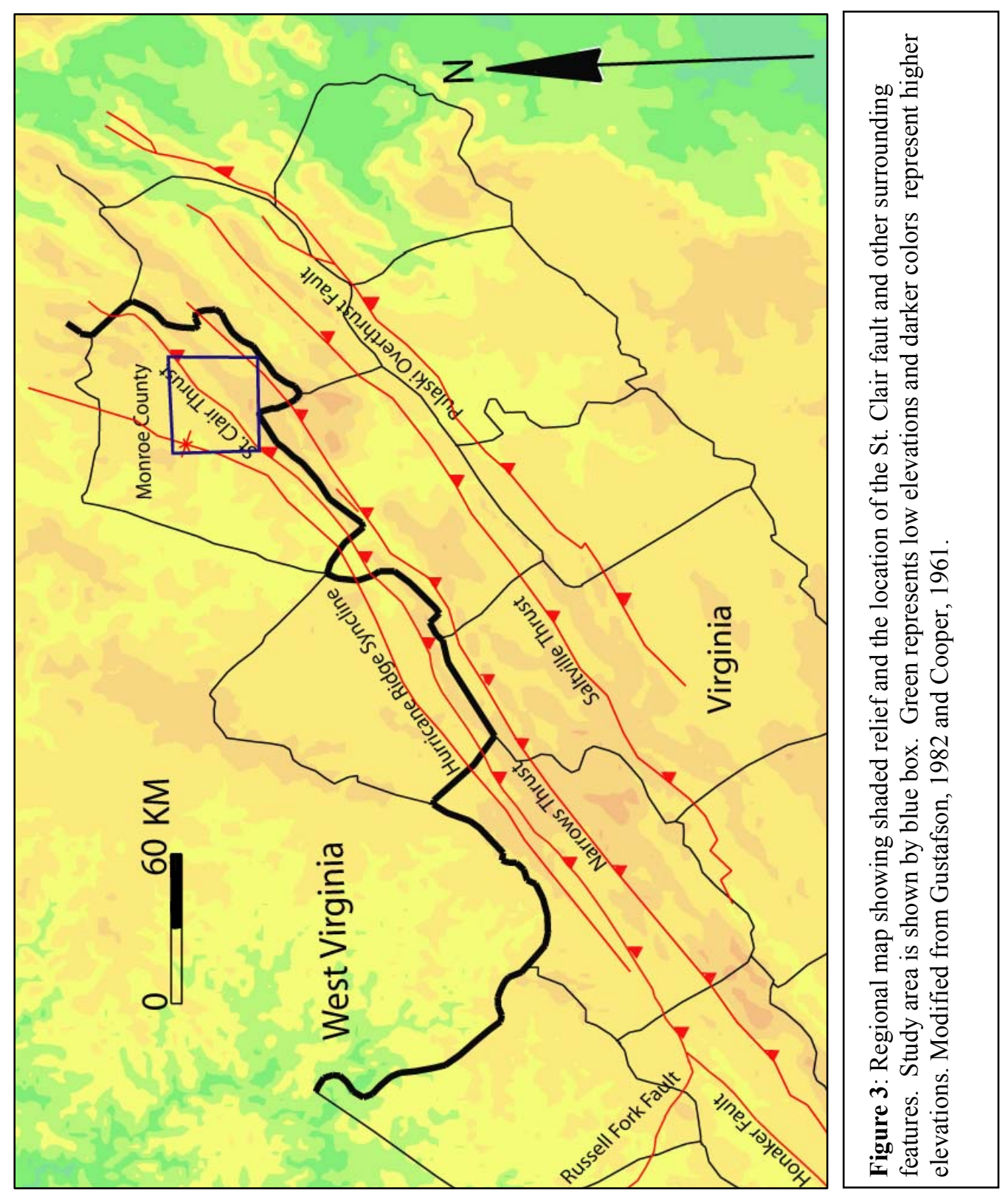




\section{Chapter 3: Stratigraphic Setting}

It is noted that "nowhere along the section is a complete stratigraphic succession exposed (Late Precambrian through Pennsylvanian)" (Woodward, 1985). The strata that will be encountered in the study area range from the older Upper Cambrian to Lower Ordovician Knox Group to the younger Upper Mississippian Mauch Chunk Group.

The following are detailed descriptions of the formations (oldest to youngest) that are encountered within the study area. The following stratigraphic descriptions are compiled with the help of Kammer (2001) and McDowell and Schultz (1989). The descriptions by Kammer (2001) are for Southeastern West Virginia and the descriptions for McDowell and Schultz (1989) are for Giles County, Va. Additional descriptions have been added based on observations within the study area. A stratigraphic column for this area can be found on Figure 4 and a chart correlating the nomenclature across regions can be found in Appendix III.

\section{Knox Group}

The dolomite sequence of the Upper Cambrian through the Lower Ordovician age belongs to the Knox Group. The Knox Group was named by Safford (1869) for exposures in Knox County, Tennessee. The Knox Group is comprised of the Beekmantown Dolomite and the Copper Ridge Dolomite. For the purposes of this study, the broader Knox Group will be used. The Knox Group contains a thick sequence of gray or tan siliceous dolomite with brecciation occurring locally. The dolomite within the Knox Group is often cherty in nature. 
Also, within the Knox Group, thin limestones and sandstones can be found, as well as flat-pebble conglomerates. Fossils are uncommon, except within the sandstone and limestone layers. The Knox Group represents marine shelf carbonates and range between $180-600 \mathrm{~m}$ in thickness, in Southeastern West Virginia. The thickness within the study area has been found to be in the upper portion of that range. The Knox Group overlies the Nolichucky shale and is overlain by the Middle Ordovician Limestone Group. An unconformity exists above the Knox Group, having as much as $30 \mathrm{~m}$ of relief. The Knox Group facies has been interpreted as being a marine shelf environment (McDowell and Schultz, 1989). Exposures of the Knox Group include areas along Zenith Road, to the west of Gap Mills and along Wallace Hollow Road, just east of the intersection of Zenith Road and Back Valley Road. These exposures are not particularly well exposed along Zenith Road, however, a few well exposed outcrops can be found along Wallace Hollow Road.

\section{Middle Ordovician Limestone}

The Middle Ordovician Limestone is composed of the New Market Limestone, Lincolnshire Limestone, and the Black River Limestone. The upper contact of the Knox Group is an erosion surface that is overlain by a sequence that is composed mostly of limestone. Within the study area the New Market Limestone may not be present. It is noted by McDowell and Schultz (1989) that in most places, the basal bed is a breccia or conglomerate that is composed of angular to subrounded clasts of light gray to black chert. The New Market Limestone (0-60 m), if present, consists of a light-gray to lightolive gray micritic limestone that is thickly bedded and might be argillaceous near the 
base. Next, the Lincolnshire Limestone (14-60 m) is a dark-gray, medium to coarse grained limestone with black chert clasts and the presence of fossils, mainly brachiopods and bryozoans, but can include trilobites, echinoderms, and corals. Finally, the Black River Limestone (60-76 $\mathrm{m}$ ) is a dark, micritic limestone with very few fossils. The Middle Ordovician Limestones often have calcite veins and are thickly bedded (more than 2 feet) within the study area. Along with the Upper Cambrian Knox Group, the Middle Ordovician Limestones form the linear valley between the northern slope of Peter's Mountain, and the southern slope of Gap Mountain. This facies represents a carbonate ramp and foreland basin deposition (McDowell and Schultz, 1989).

Within the area, the Middle Ordovician Limestones are exposed along Waiteville Road on the northern side of Peter's Mountain. Also, some exposures can be found along Zenith Road, just west of the junction of Waiteville Road and Zenith Road.

\section{Martinsburg Formation}

The Martinsburg Formation has been assigned the age of Middle and Upper Ordovician. The Martinsburg Formation was named by Geiger and Keith (1891) for exposures near Martinsburg, West Virginia. The Martinsburg Formation consists of limestone with interbeds of sandstone, siltstone, and calcareous shale near the top, and ranging down to calcareous siltstones and shales near the base. The sandstones represent mostly turbidites. The contact with the underlying Middle Ordovician limestone is gradational. The Martinsburg Formation represents a shallow marine deposition, with its sediment supply possibly originating from the Taconic Orogeny (McDowell and Schultz, 1989). Kreisa (1980) attributed most of the formation to storm deposits. 

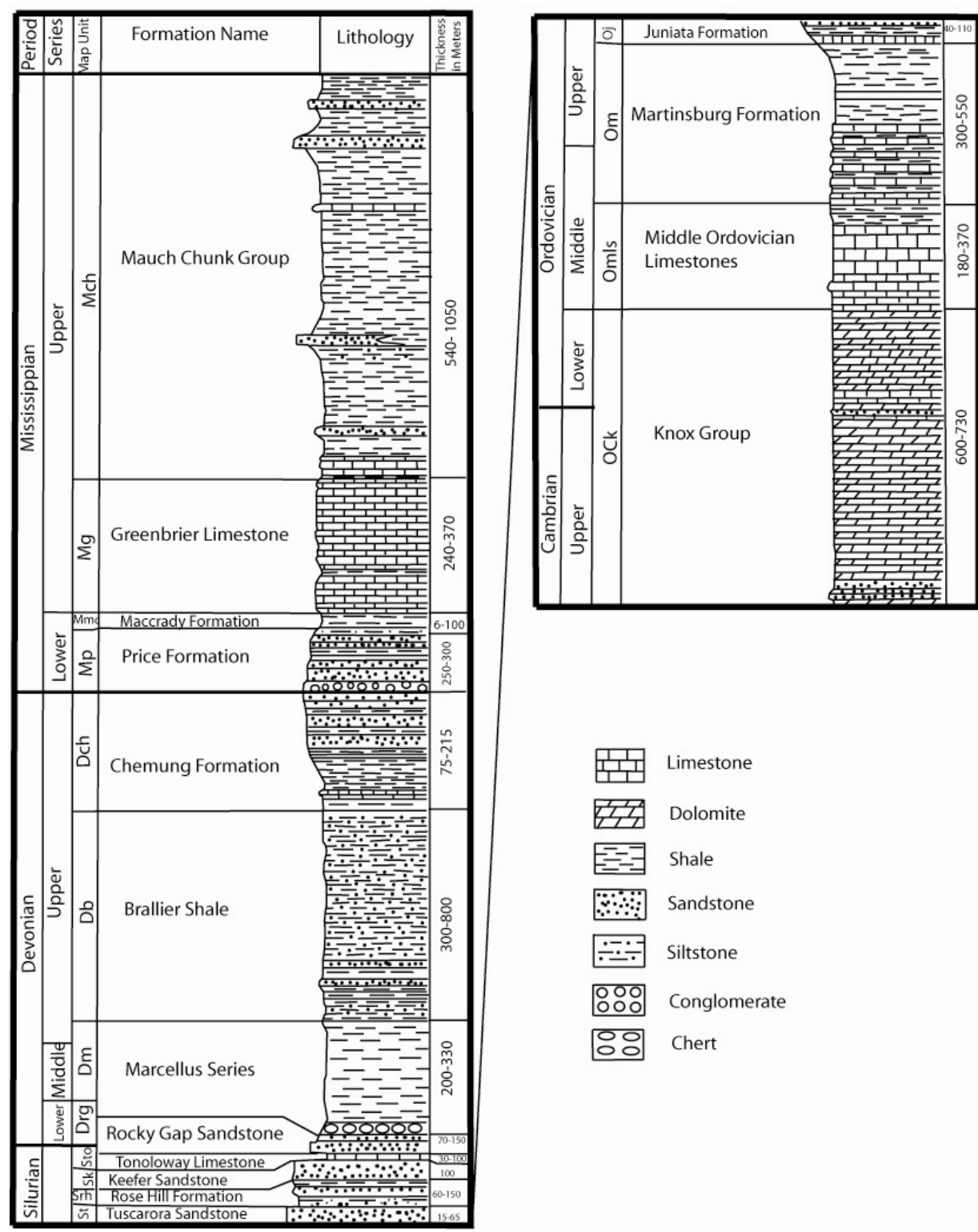

صب Limestone

Dolomite

$=-\exists$ Shale

Sandstone

羊- Siltstone

잉ㅇ Conglomerate

응응 Chert

Figure 4: Generalized stratigraphic column for the study area. Thicknesses shown are average thicknesses. Modified from McDowell and Schultz, 1989. 
The Martinsburg Formation is found mainly on the middle and lower slopes of mountains and is generally covered by colluvium (McDowell and Schultz, 1989). In the study area, although poorly exposed due to colluvium, the Martinsburg Formation can be found trending along the northern slope of Peter's Mountain and along the south slope of Gap Mountain as a thin sliver. In southeastern West Virginia, the thickness ranges from 300-730 m. Thicknesses within the study area have been found to be approximately 550

m.

\section{Juniata Formation}

The Juniata Formation was named by Darton (1896) for its occurrence along the Juniata River in Pennsylvania. The Juniata Formation (Ordovician), also known as the Red Medina, consists of equal amounts of mudstone and sandstone, with some thin shale beds. The presence of a lagoonal facies can be found on Peters Mountain, within the study area. The lagoonal facies can be identified by the presence of ostracods and the dark red color. The mudstones of the Juniata are typically a bright red color, being made up of nonmarine redbeds. The sandstone layers are typically olive in color. The presence of glauconite accounts for the color of the sandstone layers (Gustafson, 1982). The Juniata Formation was deposited mostly as a delta-plain mudflat (McDowell and Schultz, 1989). The Juniata typically can be found on steep outcrop slopes just below the crest of ridges and is commonly covered by Tuscarora Quartzite float (McDowell and Schultz, 1989). The thickness ranges from $45-180 \mathrm{~m}$. The Juniata Formation forms a gradational contact with the overlying Tuscarora Quartzite. 
In the study area, the Juniata Formation is located along the northern slope of Peter's Mountain, just below the ridge. It can also be found as a thin sliver along the southern slope of Gap Mountain. An excellent exposure of the Juniata Formation can be found along WV Route 3, just north of Gap Mills, WV (Figure 5). At this location, the Juniata Formation makes up the footwall of the St. Clair fault and has been overturned. Another good exposure is located along the Hanging Rock Trail on Peter's Mountain. For this study, the contact between the Juniata and Tuscarora Formations has been placed at the first occurrence of the massive-bedded quartzites of the Tuscarora Formation.

\section{Tuscarora Sandstone}

The Tuscarora Sandstone was named by Darton (1896) for occurrences on Tuscarora Mountain, Pennsylvania. The Clinch Sandstone was named by Butts (1940) for exposures on Clinch Mountain, Tennessee. Clinch and Tuscarora both refer to the same formation, however, according to Butts (1940), the name Tuscarora applies to that

formation in the Appalachian Valley north of the $38^{\text {th }}$ parallel while the Clinch is used in southern Virginia and Tennessee (Gustafson, 1982). The Tuscarora Sandstone (Lower Silurian) is made up of coarse-grained, well-sorted sandstone which is quartz-rich and often displays trough and planar cross-bedding. Minor lenses of quartz-pebble conglomerate are present locally. The presence of worm burrows (Skolithos and Arthrophycus) has also been noted. The Tuscarora Sandstone is very resistant and is regarded as an important mapping unit.

The ridges of Peter's Mountain and Gap Mountain are composed of the Tuscarora Sandstone. Excellent exposures of the Tuscarora Formation can be found along WV 
Route 3 north of Gap Mills, WV and along the hanging rock trail along Peter's Mountain (Figure 6). The exposure near Gap Mills, WV has been overturned. Outcrops along the Hanging Rock trail expose quartz-pebble conglomerates, crossbedding, and some Skolithos and Arthrophycus trace fossils. The depositional environment has been suggested to be a nearshore or shoreline deposit, possibly littoral marine or fluvial (McDowell and Schultz, 1989). Thickness ranges from 21-58 m.

\section{Rose Hill Formation}

Swartz (1923) named the Middle Silurian Rose Hill Formation for exposures at Cumberland, Maryland. The Rose Hill Formation is commonly grouped as part of the Clinton Group named from Clinton, New York. For this study, the Clinton Group will not be used. The Clinton group has been divided into the Rose Hill Formation and the overlying Keefer Sandstone. The Rose Hill consists of hematitic sandstone and shale, giving the formation a red color, in the lower portion of the Rose Hill. The upper portion of the Rose Hill Formation includes olive-green shales and siltstone. Ostracods and brachiopods can be found within the redbeds as well as the shales. The redbeds within the Rose Hill can be interpreted as lagoonal, due to the presence of ostracods and brachiopods.

Thick sandstone beds of the Rose Hill Formation form ledges on or just below ridge crests. The best exposure of the Rose Hill Formation within the study area can be found along the Alleghany National Trail, which runs parallel with the ridge of Peter's Mountain along the south slope (Figure 7). The Rose Hill Formation represents a marine transgression over the underlying Tuscarora Sandstone (McDowell and Schultz, 1989). The thickness in this area ranges from $64-150 \mathrm{~m}$. 


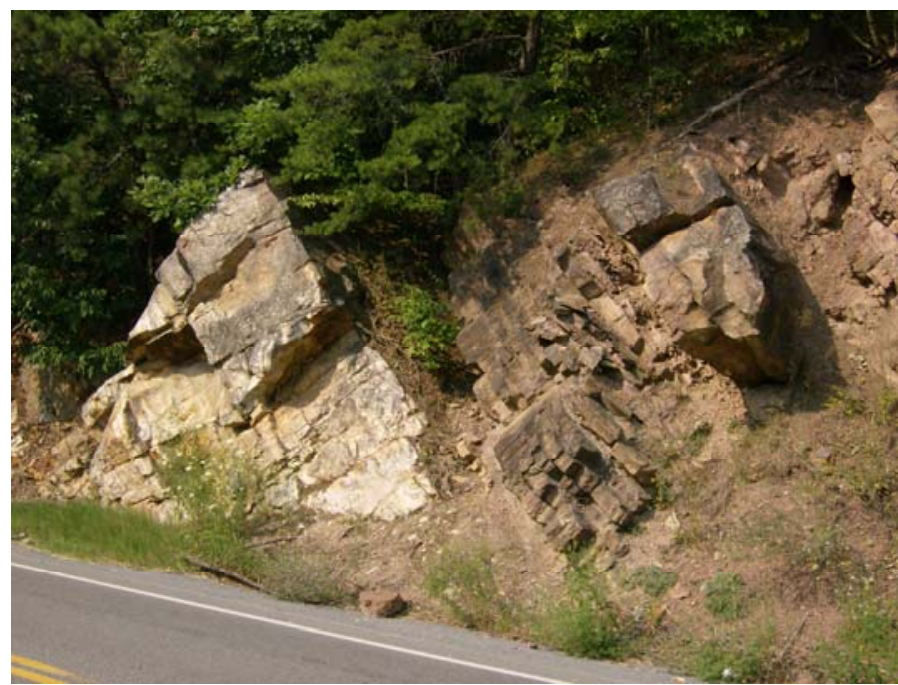

Figure 5: Outcrop along WV Route 3, just north of Gap Mills, WV showing the contact between the Juniata Formation and the overlying Tuscarora Sandstone. Note that these beds are overturned. Approximate location of picture is indicated on Figure 8.

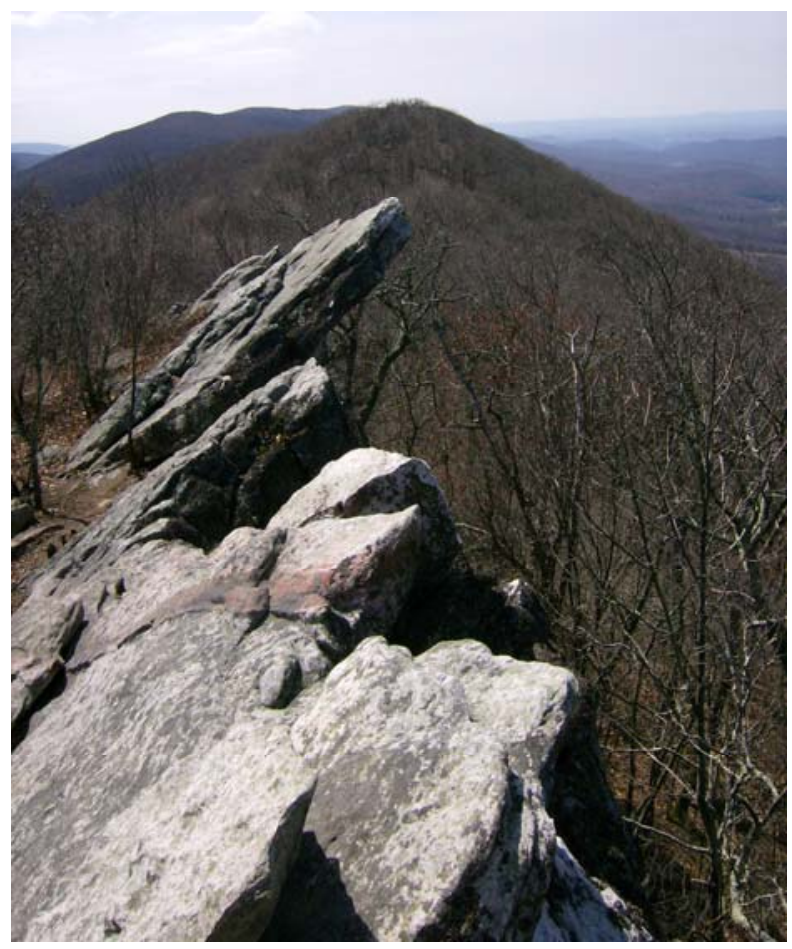

Figure 6: Outcrop of the Tuscarora Sandstone along the ridge of Peter's Mountain. Picture was taken from the Hanging Rock Observatory, looking southwest. Approximate location of picture is indicated on Figure 8. 


\section{Keefer Sandstone}

The Upper Silurian Keefer Sandstone was first named by Ulrich (1911) for exposures on Keefer Mountain, Maryland. The Keefer Sandstone, which makes up the second part of the Clinton Series, is made up of fine-grained gray-white or brown sandstone. It can also contain an upper and/or lower layer of hematite, which is around 8 inches in thickness. Some quartzite can also be found locally. There may be a presence of locally cross-bedded or ripple marked and burrowed layers (Skolithos) and minor reddish-brown sandstone beds.

The Keefer Sandstone forms prominent flatirons on dip slopes of ridges and locally crops out as ledges on the crests (McDowell and Schultz, 1989). Its thickness has been found to be approximately $100 \mathrm{~m}$. Within the study area, outcrops of the Keefer Sandstone were not readily present. However, small outcrops were found along Crowder Road, which transverses Peter's Mountain. 


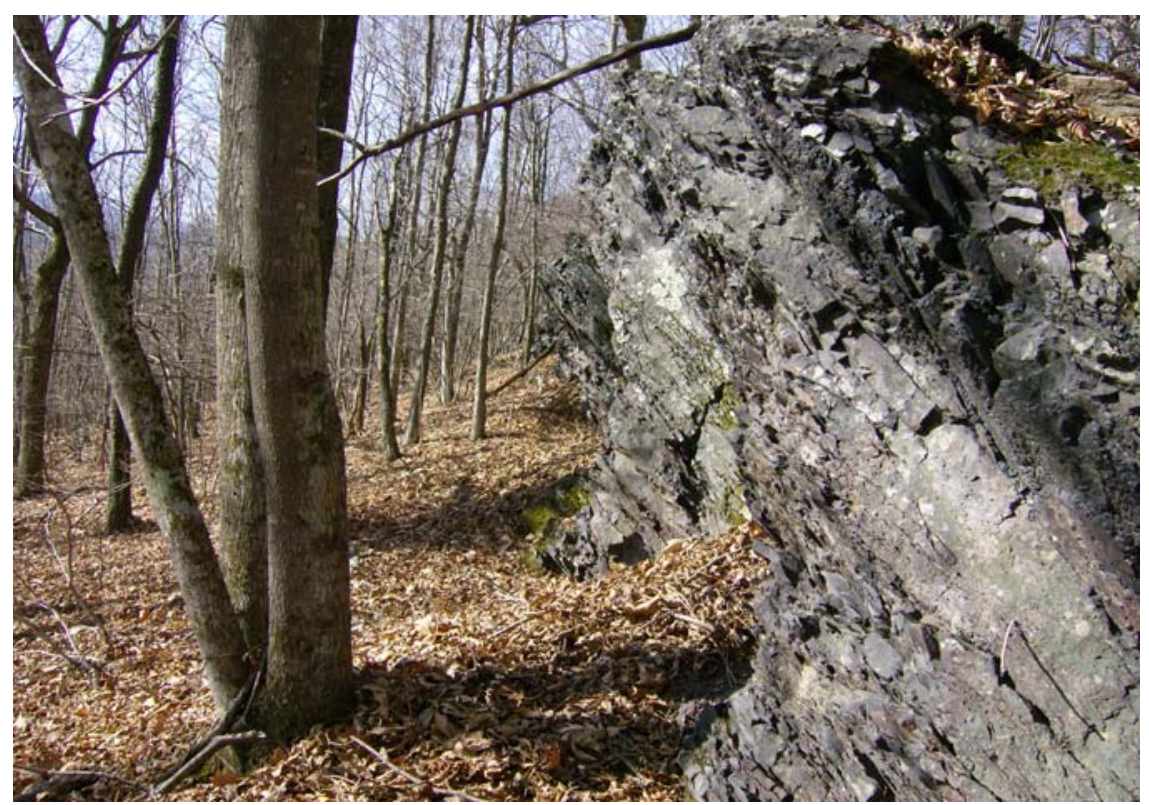

Figure 7: Outcrop of the Rose Hill Formation along the Allegheny National Trail, on the south slope of Peter's Mountain. Approximate location of picture is indicated on Figure 8. 


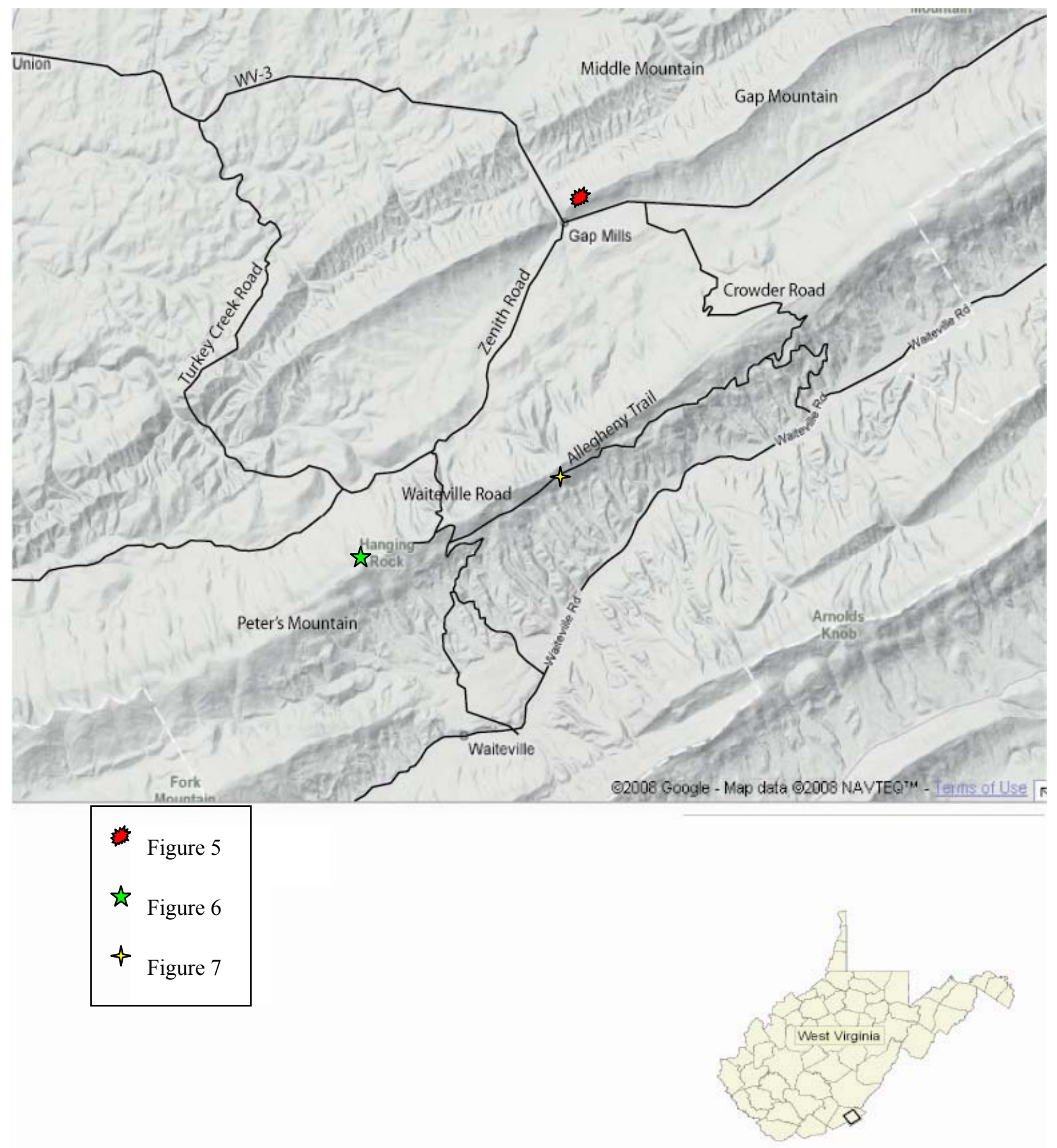

Figure 8: Terrain map showing approximate locations for Figures 5, 6, and 7. Red star represents the location of Figure 5; Green star represents location of Figure 6; Yellow star represents location of Figure 7. Terrain map from Google Maps. 


\section{Tonoloway Limestone}

The next formation is the Tonoloway Limestone (Silurian). However, between the Keefer Sandstone and the Tonoloway Limestone, it is possible to find the Rochester Shale (0-6 m), McKenzie Formation (0 -43 m), Williamsport Sandstone (0-15 m), and the Wills Creek Formation $(0-67 \mathrm{~m})$. These formations did not appear within the study area. The Tonoloway Limestone was named by Ulrich (1911) for outcrops on Tonoloway Ridge in Maryland. The Tonoloway Limestone is a thin, poorly exposed limestone sequence. The Tonoloway Limestone was not observed as outcrop in the study area. The presence of the Tonoloway Limestone is often indicated by reddish-brown clayey soil, small sinkholes, or a distinct slope break (McDowell and Schultz, 1989). Some calcareous shale might also be present. Near the top of the Tonoloway Limestone, calcareous siltstone and shale, cross-laminated sandstone, and fossiliferous limestone can be found. Fossils are uncommon, but occasional layers of ostracods and stromatolites can be found. Thickness within the study area can range from 30-100 m, and can be as little as $15 \mathrm{~m}$.

\section{Rocky Gap Sandstone}

The Helderberg Group and the Oriskany Sandstone (Devonian) are being combined for the purpose of this project to form the Rocky Gap Sandstone. The name Rocky Gap was given to this formation by Swartz (1929) for exposures near Rocky Gap, Virginia. This is being done because the Oriskany Sandstone is only 8-23 m thick in the study area. The Helderberg Group (60-120 m) ranges from carbonate mudstone to grainstone (limestone). The Helderberg is typically fossiliferous and cherty. Fossils that can be found within the Helderberg Group include crinoid stem molds. This unit weathers 
a distinct light brown color. The Helderberg Group is interpreted as being shallow water limestone.

Above the Helderberg Group, but still within the Rocky Gap Sandstone, is the Oriskany Sandstone. The Oriskany Sandstone is a medium to coarse-grained calcareous sandstone; the calcareous cement is easily removed by weathering, which leaves a friable, indistinctly bedded outcrop. Fossils might be common, which include brachiopods and crinoid stems. Outcrops of the Oriskany Sandstone occur in stream beds along Waiteville Road, on the southern slope of Peter's Mountain.

\section{Marcellus Series}

The Marcellus Series (Devonian) consists of the Huntersville Chert (9-23 m) and the Millboro Shale (46-300 m). Once again, these two formations are being combined due to the thinness of the Huntersville Chert. The Lower Devonian Huntersville Chert was first described by Price (1929) in Huntersville, West Virginia. The Huntersville Chert is a highly silicified black shale, or chert, that contains beds that are brecciated and recemented with amorphous silica. When weathered, the shales are often pink or lavender in color and the chert might be blue or blue-black. The top of the Huntersville Chert is marked by glauconitic sandstone, known as the Bob's Ridge Sandstone, which is approximately $3 \mathrm{ft}$ thick. A small exposure of the Huntersville Chert can be found on the southern slope of Peter's Mountain, along Waiteville Road.

The Devonian Millboro Shale was named by Butts (1940) for exposures at Millboro Springs, Virginia. The overlying Millboro Shale is an olive-gray to grayishblack fissile clay shale that weathers gray and readily forms soil. Color can range from 
brown and red to white. The shale might be sparsely fossiliferous in the study area. McDowell and Schultz (1989) note that the Millboro Shale occurs locally just below the St. Clair thrust on the overturned limb of the Glen Lyn Syncline. The Millboro Shale is poorly exposed on the footwall block, north of Gap Mills, WV. However, on the hanging wall, the Millboro Shale is nicely exposed on the south slope of Peters Mountain. The thickness of the Millboro Shale is difficult to determine because of repetition of beds by folding and faulting, but Cooper (1961) reported a thickness of 259 to $304 \mathrm{~m}$ (McDowell and Schultz, 1989).

It is beginning to become apparent that the Marcellus is a viable resource for natural gas. It has been estimated by the Potential Gas Committee that the Marcellus could increase the probable resource numbers by 50 TCF (Durham, 2008). Within the study area, the Marcellus has the most, if not only, potential for natural gas production. It has been suggested that the Marcellus will be prospective on a multiple play basis just as with the Barnett Shale (Durham, 2008). The one upside of the Marcellus is its regional extent, covering approximately 600 miles, the Barnett Shale covers only 120 miles. However, due to the large extent of the Marcellus, it will take more work to pinpoint a specific area to begin drilling (Durham, 2008).

\section{Brallier Shale}

The Upper Devonian Brallier Shale was named by Butts (1918) for exposures near Brallier Station in Bedford County, Pennsylvania. The Brallier Formation, also known as the Portage, consists of siltstones and mudstones of marine origin. Some finegrained, thickening upwards sandstones can also be found in the Brallier Formation. The 
beds are typically dark brown to gray in color. The upper contact with the Millboro Shale is gradational and is generally placed at the base of the lowest, medium-grained, cross-bedded, fossiliferous sandstone $6 \mathrm{ft}$ thick, or more. McDowell and Schultz (1989) note that the Brallier outcrops along the footwall of the St. Clair thrust fault in Giles County, Va. Thickness ranges from $120-760 \mathrm{~m}$. The Brallier Formation is interpreted as being distal flysch deposits, such as turbidites (McDowell and Schultz, 1989).

\section{Chemung Formation}

The Chemung Formation (Devonian) consists of thick-bedded, fine-grained, slightly calcareous sandstone with interbeds of siltstone and shale. Some of the sandstones near the top of the Chemung are highly fossiliferous, containing mostly brachiopods. Sandstones within the Chemung Formation have sole marks and may be turbidites of a proximal flysch facies (McDowell and Schultz, 1989). This sequence represents a marine depositional environment. An excellent exposure can be found along WV Route 3, a little over one-half mile north of Gap Mills, WV. A highly fossiliferous bed of the Chemung Formation is located just north of the bridge over Second Creek, along WV Route 3. The thickness ranges from 150-900 m. Above the Chemung, the Hampshire Formation (0-250 m) may be present, but not seen regionally.

\section{Hampshire Formation}

The Upper Devonian Hampshire Formation consists of entirely nonmarine sandstones, shales, and mudstones, usually being pink to bright red in color. The sandstones within the Hampshire Formation are typically cross-bedded. Thicknesses for 
the Hampshire range from 0 to $250 \mathrm{~m}$. The Hampshire was not expected to be located within the study area. However a thin non-mappable sliver, less than 1 meter thick, of the Hampshire Formation was found along Turkey Creek Road.

\section{Price Formation}

The Chemung and the Hampshire Formations are overlain by the Late Devonian and Early Mississippian Price Formation, which was named by Campbell (1894) for exposures on Price Mountain in Montgomery County, Virginia. The Price Formation consists of planar-cross-bedded sandstone with beds of siltstone and shales of marine origin increasing upwards. Multiple, thinly bedded, fine to medium-grained sandstone, shale, siltstone, coal, and conglomerates can be found (Johnson, 2007). Fossils are present, but not common. At the base there is often a nonmarine conglomerate known as the Cloyd Conglomerate. The Cloyd Conglomerate was deposited by a regressiontransgression sequence during the late Devonian in estuarine point bar and fluvial channel environments (Bjerstedt and Kammer, 1988, Bjerstedt, 1986, and Johnson, 2007). McDowell and Schultz (1989) note that the Price Formation has been described as a regressive sequence composed of lithofacies representing eight depositional environments, ranging from marine shelf to delta plain and swamp. In southern West Virginia, the Price Formation has been interpreted as being deep water marine-deltaic in origin (Johnson, 2007).

Exposures of the Price Formation, and the Cloyd Conglomerate, can be found along WV County Route 8, just east of the study area. Another excellent exposure is located along Turkey Creek Road. The exposure along Turkey Creek Road shows cross- 
bedded sandstones, layers of rip-up clasts, some fine-grained sandstone and siltstones, as well as the contact between the Price Formation and the underlying Hampshire Formation. The thickness of the Price Formation in southern West Virginia, near the town of Caldwell is $286 \mathrm{~m}$ (Johnson, 2007).

\section{Maccrady Formation}

The Price Formation grades upward into and interfingers with the Maccrady Formation. The Mississippian Maccrady Formation was named by Stose (1913) for the town of Maccrady, Virginia. The Maccrady Formation consists of typically bright red mudstones and sandstones of nonmarine origin. The Maccrady might contain beds of gypsum, anhydrite, and salt. The thickness of the Maccrady Formation in the study area ranges from 8-107 m. The Maccrady Formation has been interpreted as being deposited in a shallow, arid marine basin that was actively subsiding on its eastern margin (McDowell and Schultz, 1989).

\section{Greenbrier Limestone}

Although its first use is unclear, the name is derived from the Greenbrier River in nearby Greenbrier and Pocahontas Counties, West Virginia. The unit is generally given a formational rank in Virginia and a group rank in West Virginia (McDowell and Schultz, 1989). The Greenbrier Limestone (Mississippian) is composed of medium to dark-gray, locally fossiliferous limestone with chert clasts or beds. Fossils include crinoid stems. Good exposures of the Greenbrier Formation can be found along WV Route 3 between the town of Union and the first occurrence of the Maccrady Formation near the base of 
Middle Mountain. Just east of the town of Union, W.V. along W.V. Route 3, few of the crinoid stems observed reached more than six inches in length. Beds of the Greenbrier Limestone which contain chert nodules can be located near the small town of Keenan, along WV Route 3. The beginning of the Greenbrier Formation was mapped by the first occurrence of limestone outcrops or the presence of sinkholes. The presence of the Greenbrier also coincides with the presence of pasture land within the study area. The Greenbrier represents a shallow water depositional environment, possibly a shallow marine shelf. Thickness of the Greenbrier ranges from 230-550 m.

\section{Mauch Chunk Group}

Above the Greenbrier Limestone is the Mississippian Mauch Chunk Formation, named by Lesley (1876) for exposures at the town of Mauch Chunk, Pennsylvania. The Mauch Chunk Group consists of the Bluefield Group (argillaceous and fossiliferous limestone and calcareous shale), Hinton Group (red, green, and gray arenaceous shale and calcareous siltstone with few beds of fossiliferous limestone and coal), Princeton Sandstone (light to medium-gray resistant sandstone or conglomerate), and the Bluestone Group (red to gray shale with lesser amounts of sandstone and siltstone and a few thin coal beds).

Exposures of the Mauch Chunk within the study area are limited to the western side of Zenith Road, near the town of Rock Cave, W.V. The Mauch Chunk Group is primarily a sequence of red and variegated shale or mudstone and sandstone and siltstone to a lesser degree. An occasional thin marine limestone with fossils can be found. The total thickness for the Mauch Chunk Group ranges from 540-1050 m. 


\section{Sequences}

By the end of the Cambrian (Knox Group), a shallow sea covered essentially all of present-day West Virginia. During this time as well as most of the Ordovician Period, marine deposition was prevalent. Then, near the end of the Ordovician, the Taconic Orogeny formed a high mountainous area to the east of present day West Virginia. This mountainous area was the main source of sediments for the succeeding Silurian Period and the Early Devonian Period. Both clastics and carbonates were deposited in a mixed marine and nonmarine environment. Then, during the conclusion of the Devonian Period, the Acadian Orogeny resulted in a further source for clastic marine deposits. However, near the end of the Devonian, the sea was retreating westward and the continental redbeds of the Hampshire Formation were deposited. The Greenbrier Formation is the last marine deposit of significance in West Virginia (WVGES, 2006).

The stratigraphy of the study area can be grouped into two sequences, each consisting of a regression and a transgression. The first sequence can be located between the unconformity, between the Upper Cambrian and Lower Ordovician Knox Group and the Middle Ordovician Limestones, and the Devonian Chemung. Within this first sequence, there is a regression from the Middle Ordovician Limestones to the Silurian Tuscarora Sandstone. The Silurian Rose Hill Formation represents the first occurrence of the transgression, which continues until the Devonian Chemung Formation. The second sequence includes a regression during the deposition of the Mississippian Price and Maccrady Formations and then a transgression beginning with the Mississippian Greenbrier Formation. 


\section{Chapter 4: Structural Setting}

Thrust sheets were driven westward over underlying Precambrian basement rocks during the Alleghenian Orogeny. The Alleghenian Orogeny represents the most recent of mountain building events in the study area (Kulander and Dean, 1986). Two major phases of deformation affected the Alleghenian foreland during this time. Within the study area, the major folds and faults were formed during the late phase of the Alleghenian Orogeny, which occurred during the Late Pennsylvanian and Early Permian (Shumaker, 1996).

The Allegheny structural front separates the more intensely deformed Paleozoic sedimentary strata of the Valley and Ridge structural province to the south from the much less deformed Paleozoic strata in the Appalachian Plateau structural province to the north. In the Valley and Ridge province, large scale decollements control the major structures, while smaller amplitude structures can be found in the Appalachian Plateau (Kulander and Dean, 1986; Kulander. 1987). Within the Central Appalachians, crustal shortening in the fold and thrust belt has been estimated to be between $24 \%$ and $38 \%$ depending upon the location examined (Kulander and Dean, 1986). The magnitude of Alleghenian folding and faulting decreases from east to west across the fold and thrust belt and Appalachian Plateau.

At the Allegheny structural front, the Mississippian Mauch Chunk Formation to the Devonian Beekmantown Formation is folded into a major recumbent syncline (known as the Hurricane Ridge syncline) and is cut by the St. Clair thrust fault. It was originally thought that the Hurricane Ridge syncline was synonymous with the Glen Lyn syncline (Figure 2). However, it has recently been shown by McDowell and Schultz that the 
Hurricane Ridge syncline is actually a separate structure of different form, trend, and tectonic significance by R. McDowell (McDowell and Schultz, 1989). The Glen Lyn syncline is just northwest of and parallel to the St. Clair fault, where the southeastern limb is vertical to overturned, dips as low as $30^{\circ} \mathrm{SE}$, and the northwestern limb is flat to gently dipping.

The foreland fold and thrust belt of the Southern Appalachian Valley and Ridge Province is characterized by a series of linear to slightly arcuate, areally extensive interleaved thrust slices that truncate regional scale anticlines and synclines (Stanley, 1983). Several thrust sheets occur within or near the study area. These include the St. Clair-Narrows sheet, the Saltville sheet, and the Pulaski sheet. It has been estimated by Stanley (1983) that there has been $4000 \mathrm{~m}$ of thrusting along the St. Clair fault. The St. Clair Fault represents a specific type of faulting and folding; known as fault-propagation folding, or thrust tip-line folding. Seismic data from the Southern Appalachians confirms the existence of a regional decollement beneath the Valley and Ridge Province and possibly beneath the Blue Ridge and Piedmont Provinces (Woodward, 1985). Structures in this part of the Appalachians appear to be affected primarily by Alleghenian thinskinned tectonics above decollement horizons (Dean, Kulander, and Williams, 1979).

Stanley (1983) describes two distinct types of footwall structures. The first is an areally extensive overturned block of strata bounded by faults and the second type is subthrust synclines. The Hurricane Ridge and Glen Lyn Synclines both represent subthrust synclines. Subthrust synclines, such as the Glen Lyn Syncline, present interesting geometric and kinematic problems. 

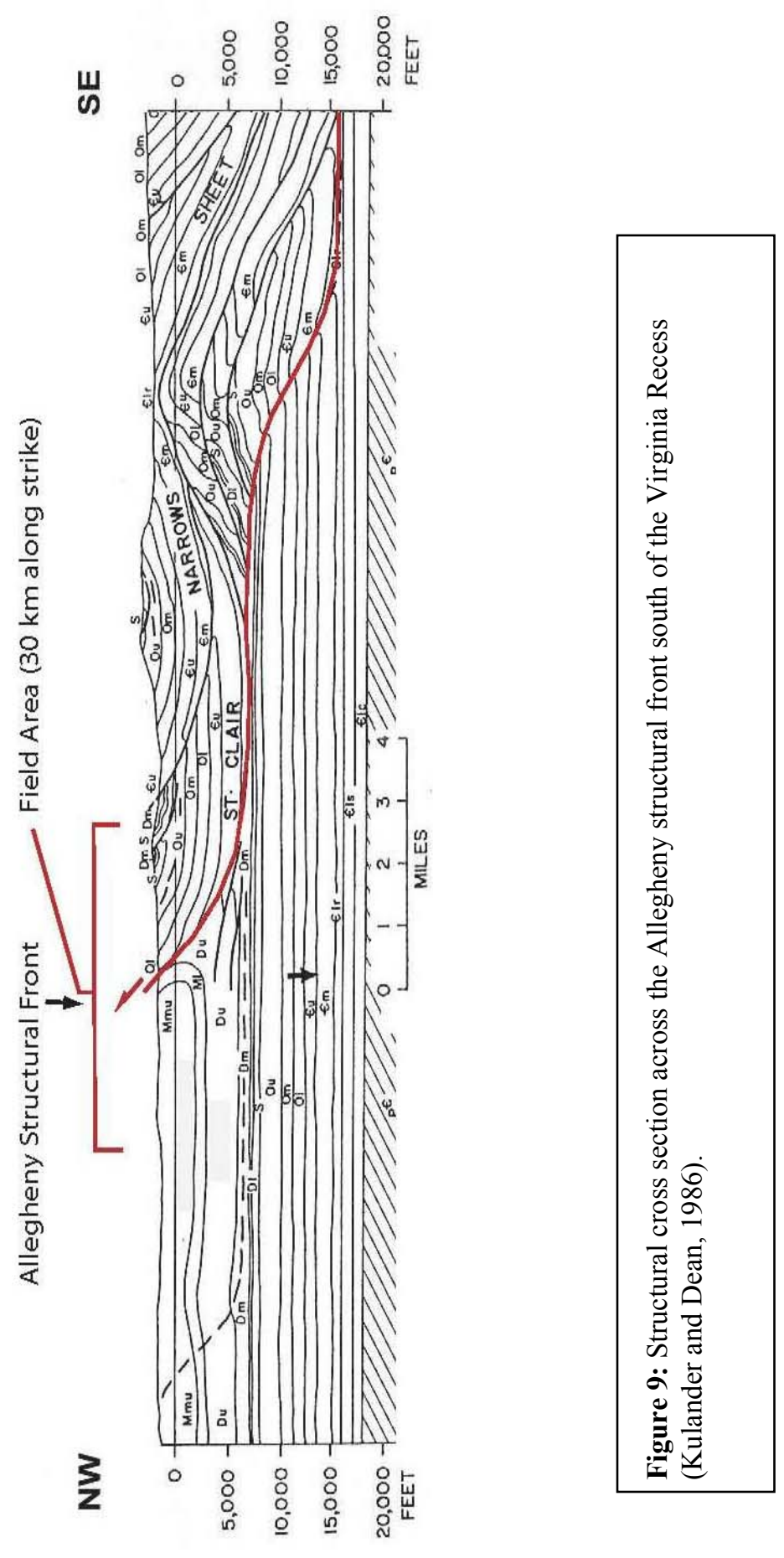
Difficulties from subthrust synclines arise in attempting to model cross-sectional geometries that account for the transition from an overturned syncline at the surface to a hypothesized subhorizontal base of deformation in the subsurface (Stanley, 1983). To explain subthrust synclines, three kinematic models were examined: fault-propagation folding, trishear deformation, and faulted detachment folds.

\section{Fault-propagation Folding}

The transfer of fault related shortening to fold related shortening was first described by Dahlstrom (1969) for the Turner Valley anticline from the foothills of the Canadian Rockies (Mitra, 1992 and Dahlstrom, 1969). The term fault-propagation fold refers to a fault related fold, in which a thrust fault loses slip and terminates up-section by transferring its shortening to a fold developing at its tip (Figure 11) (Mitra, 1992). Suppe (1985) defines fault-propagation folds as folds that represent deformation that takes place just in front of the propagating fault surface (Erslev, 1991). Another way to describe a fault-propagation fold is as a fold that has been generated by the folding strains at the tip of the ramp section of the fault where the thrust displacement reaches zero. Here a distinctly asymmetric fold with a steep to overturned fore-limb is formed (McClay, 1998). The term fault-propagation folding is used to explain the common association of asymmetrical folds with one steep or overturned limb adjacent to thrust faults (Suppe and Medwedeff, 1990).

Fault-propagation folding is characterized by steep to overturned forelimbs and faulted out synclines in the footwall of the propagating thrust fault (Figure 11). Figure 11 represents the evolution of a fault-propagation fold. It is important to notice that as the fault-propagation fold evolves, and the beds begin to overturn, there is significant 
thinning of the strata. It is also important to note that there is no development of a footwall syncline in the model of a fault-propagation fold. This lack of a footwall syncline makes the trishear model much more attractive.

Fault-propagation folds are common at leading edges of thrust faults (McClay, 1998). The subsurface position of the ramp structure can be predicted by projecting the axial surface of the leading synclinal fold down section to the tip line of the fault. Previous models of fault propagation folding used kink-band geometries to approximate folding in front of propagating thrusts. However, kink-band kinematics cannot replicate the curved fold surfaces and complex strain patterns in fault-propagation folds (Erslev, 1991). 


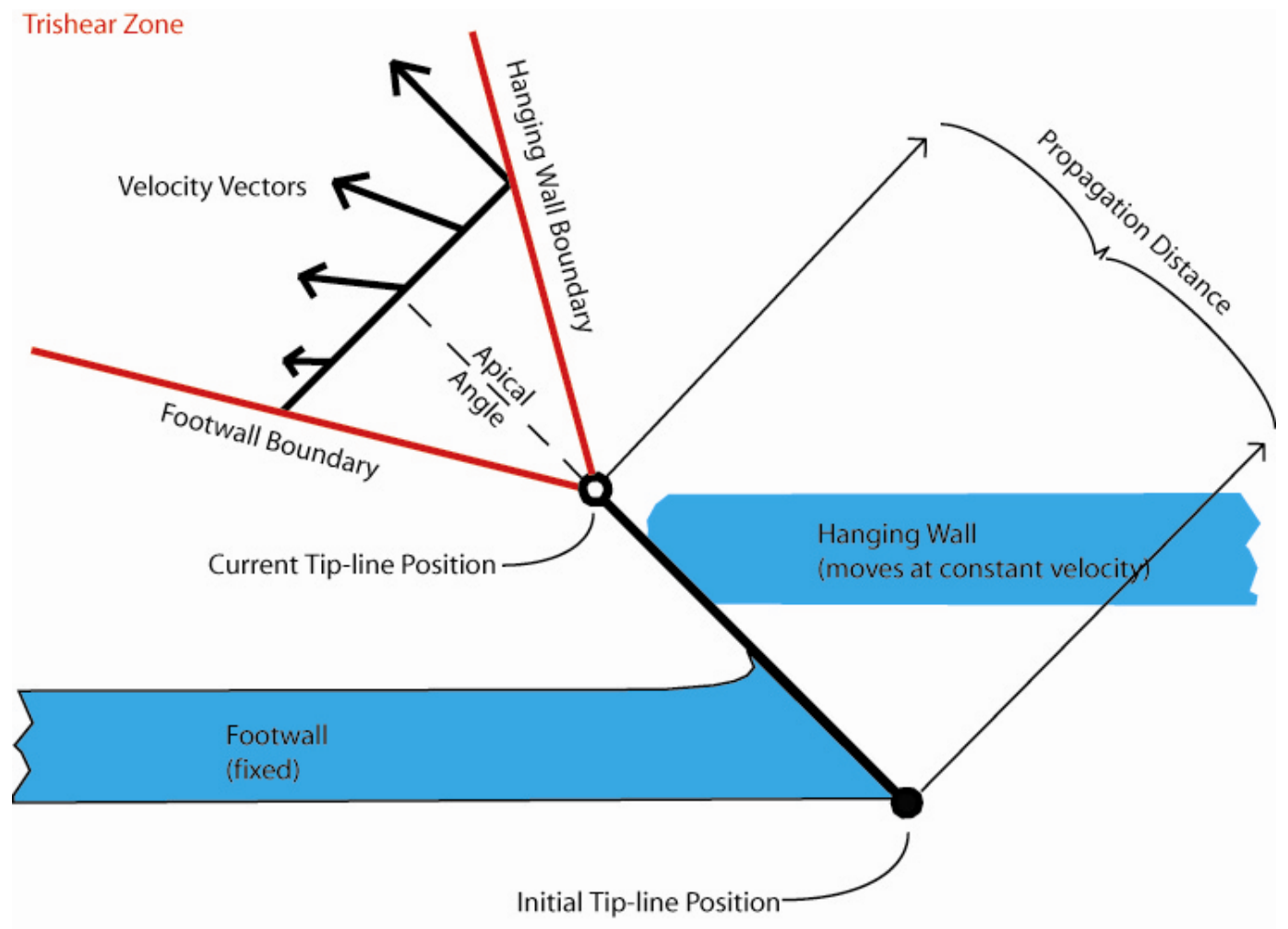

Figure 10: Diagram showing trishear kinematics, the trishear zone is indicated by red lines. (Modified from Allmendinger, 1998 and Allmendinger et al., 2004) 

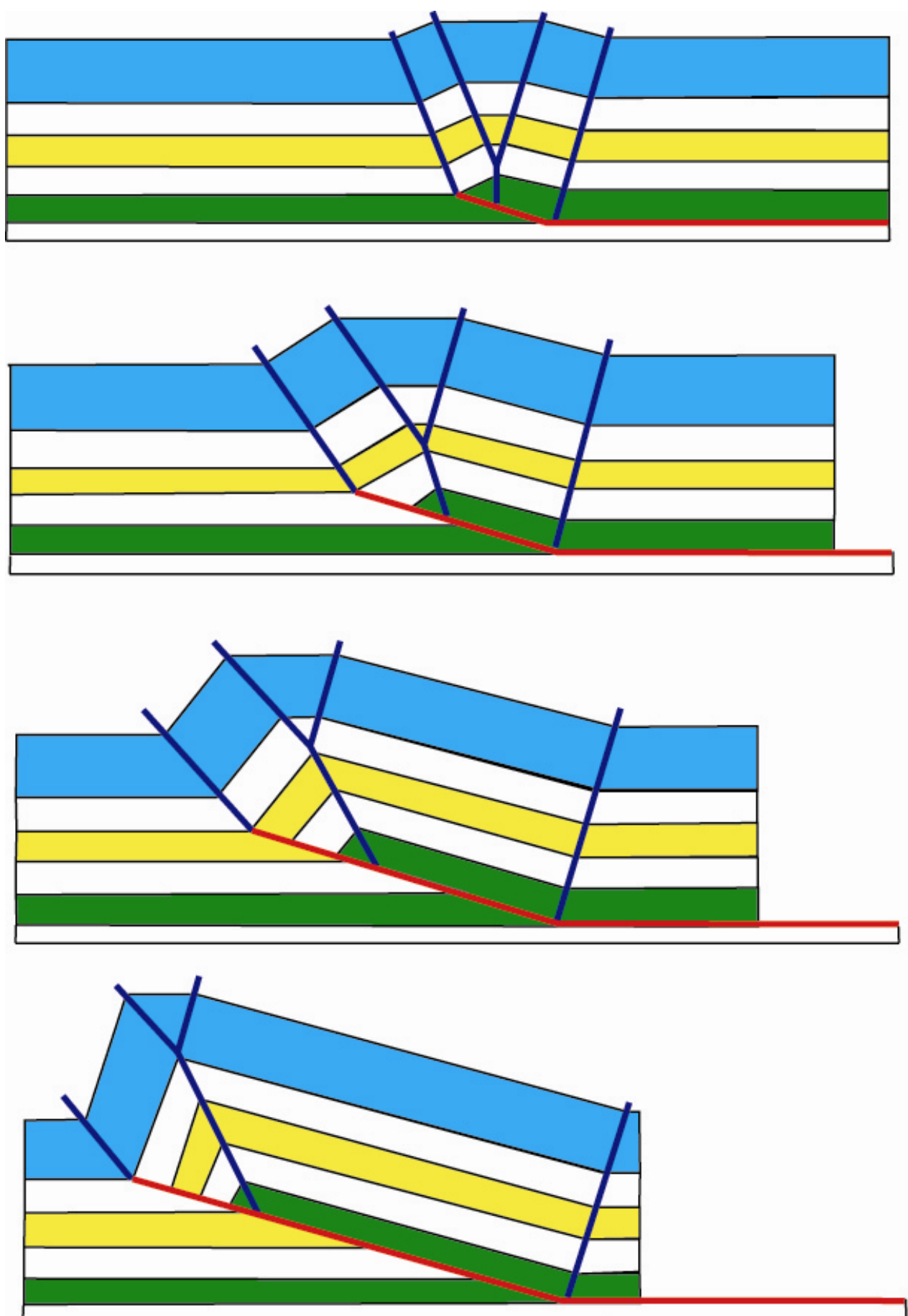

Figure 11: The evolution of a fault-propagation fold modified from Mitra (1992). Note that there is no development of a footwall syncline. Also, the strata are thinned as they are overturned. 


\section{Trishear Deformation}

Fault-propagation folds often display footwall synclines as well as changes in stratigraphic thickness and dip on their forelimbs. Previous models of fault-propagation folding used kink-fold geometries to approximate this folding in front of propagating thrusts. However, kink-fold kinematics cannot replicate the curved fold surfaces and complex strain patterns in natural and experimental fault-propagation folds (Erslev, 1991). The zone of folding within fault-propagation folds has been found to be triangular in cross section. The triangular geometry of the zone of deformation suggests that trishear deformation, formerly known as "forced folds," may provide an alternative model for fault-propagation folding (Erslev, 1991 and Allmendinger et al., 2004).

The trishear model predicts the progressive tightening of the fold and steepening of the forelimb with time. It also suggests a steeper frontlimb in lower stratigraphic units (Mitra, 2002). Early attempts to model cases where thickness and dip change were made by geometric or kinematic exercises. However in 1991 Erslev proposed two strikingly different, kinematically explicit models for fault-propagation folds called the "trishear" model, in which many geometries can be reproduced (Allmendinger, 1998). Trishear assumes a ductile rheology within the triangular shear zone (Erslev, 1991). Erslevs' two types of trishear deformation were termed homogeneous and heterogeneous (Figure 12). Homogeneous trishear uniformly rotates the tie line throughout deformation, forming a single inclined tie line. Increased deformation in the shear zone center can be approximated by heterogeneous trishear. With heterogeneous trishear, the segments of tie lines in the center of the triangular zone rotate more than those near the triangle boundaries (Johnson, 2002). Heterogeneous trishear can be modeled by subdividing each 
increment of trishear into a series of trishear stages with progressively narrowing apex angles (Erslev, 1991). Notice that in Figure 12, footwall synclines form for thrust faults and reverse fault in both the homogeneous and heterogeneous trishear models. However, the footwall syncline is much more pronounced under the heterogeneous trishear model.

Trishear deformation resembles both the geometry and the finite strain field of fault-propagation folds in thick and thin skinned provinces (Cardozo et al., 2003; Erslev, 1991; Allmendinger, 1998). Also, trishear is a powerful tool that can be used to construct balanced cross-sections of fault-propagation folds, to predict the distribution and orientation of fractures in the folds, and to estimate the nucleation point of underlying blind thrusts (Cardozo et al., 2003; Erslev, 1991; Hardy and Ford, 1997; Allmendinger, 1998).

Then in 1997 Hardy and Ford expanded Erslev's 1991 trishear model, to present a clear mathematical formulation of the problem, having analyzed the effect of variable propagation-to-slip ratio $(\mathrm{P} / \mathrm{S})$ and illustrated growth strata geometries that are associated with trishear fault-propagation folds (Allmendinger, 1998). Allmendinger (1998) stated that in the trishear model, a single fault in "basement" expands outward into a triangular zone of disturbed shear (Figure 13). The reason for the triangular shape of the shear zone must ultimately lie in the still largely unexplored mechanics of trishear." It has been shown by Erslev and Rogers (1991) that to conserve cross-sectional area the triangular zone must be symmetric with respect to the fault (Figure 10). At the top of the trishear zone, slip vectors are equal to that of the hanging wall: that is they are parallel and equal in magnitude to the master fault. At the base of the trishear zone, the slip vector varies 


\section{Homogeneous Trishear}

Footwall-Fixed Hanging-Wall-Fixed

A
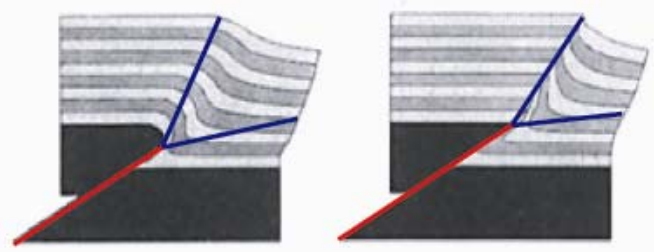

B
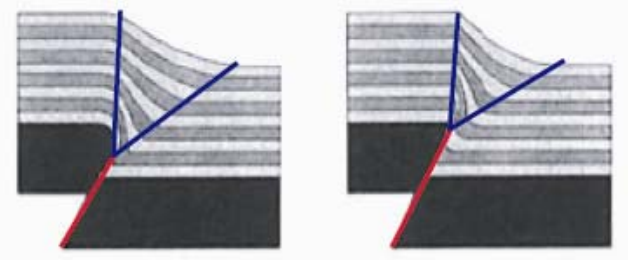

C
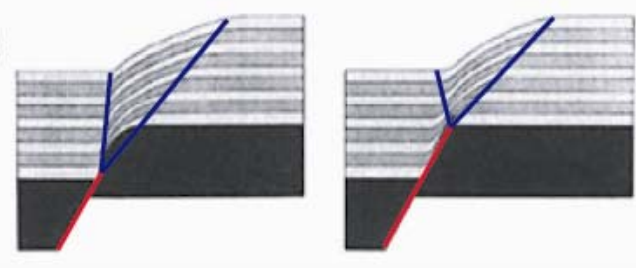

Heterogeneous Trishear Footwall-Fixed Hanging-Wall-Fixed
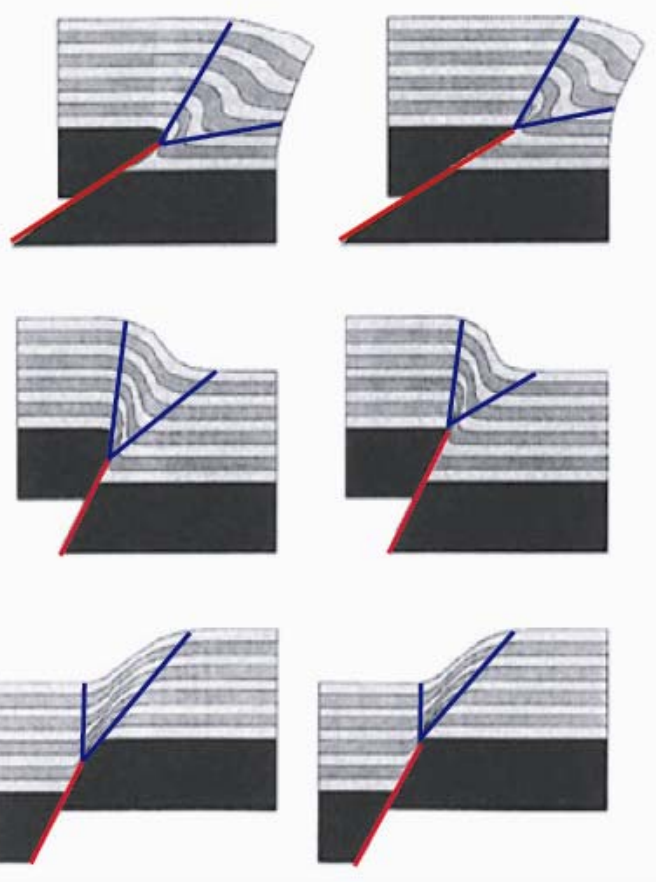

Figure 12: Homogeneous and heterogeneous fault propagation folding above (A) thrust, (B) reverse, and (C) normal faults (Erslev, 1991). The blue lines represent the triangle zone boundaries. 


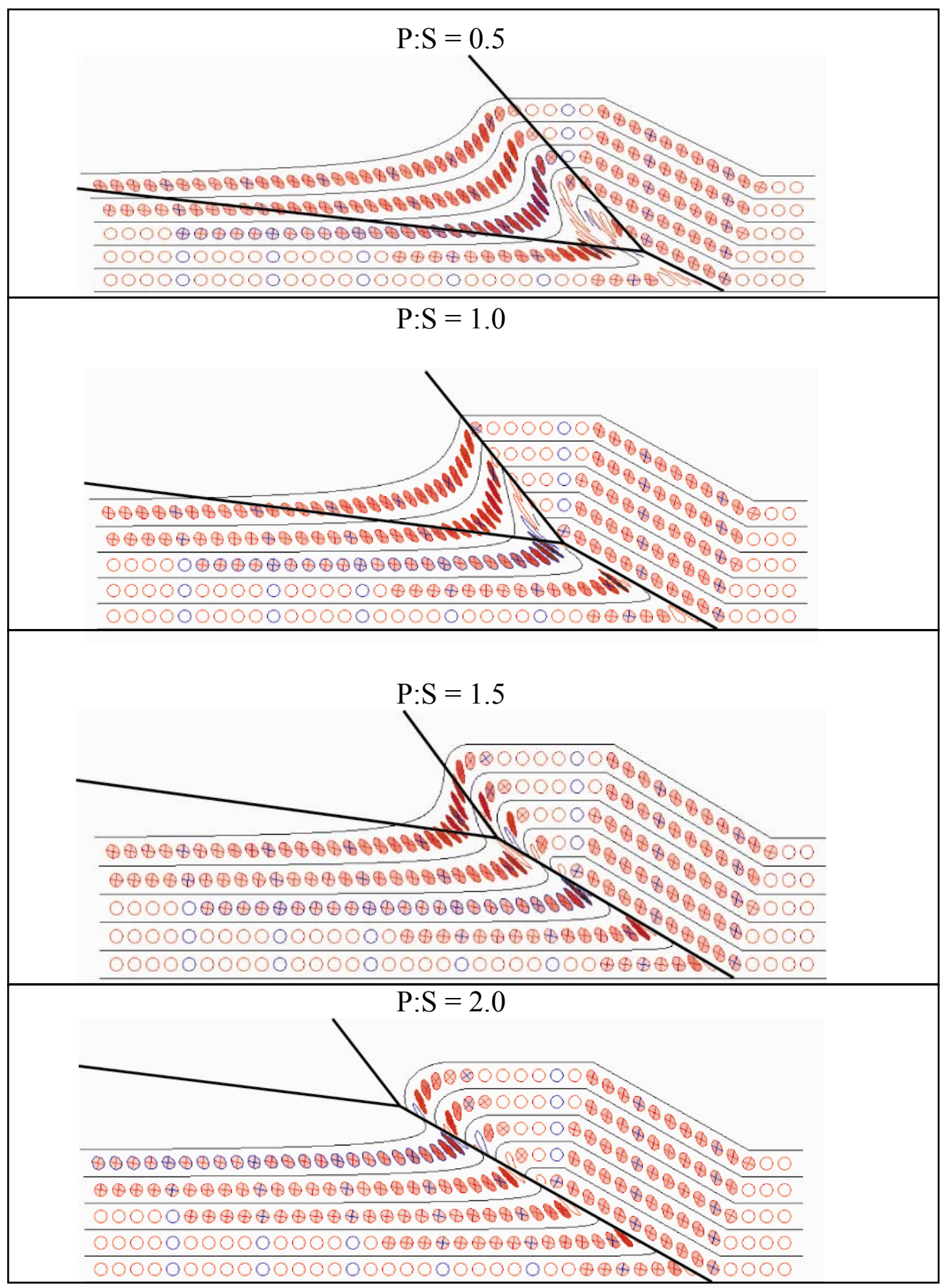

Figure 13: Changes in strain as the propagation-to-slip ratio changes. Markers within the beds indicate the orientation of the lines of no finite elongation (LNFE's). Figures created in FaultFold4.5.4 (Allmendinger 1998: Zehnder and Allmendinger, 2000). 
linearly in magnitude and orientation from top to bottom (Figure 10) (Allmendinger, 1998).

The strain field within the trishear zone has been found to be heterogeneous and continuous (Figure 13). Because the shear planes are oblique to layering, the folding within the trishear zone involves changes in thickness of the layers. In general, the beds thicken during the early stages of deformation but begin to thin as they steepen and later overturn. Trishear is one of the few fold kinematic models that can predict heterogeneous strain distribution. Shear-fracture orientations appear to be very well predicted by lines of no finite elongation (LNFE's) in trishear models (Allmendinger et al., 2004). Allmendinger (1998) has suggested that lines of no finite elongation can be used as proxies for shear plane orientations.

Also, trishear is able to successfully predict small reverse faults in the hanging walls of normal faults and small normal faults in the footwalls of thrusts. It is possible to predict opening mode fractures (such as joints) by assuming that they should be orientated perpendicularly to the long axis of the finite-strain ellipse (Allmendinger et al., 2004). Therefore, this strain within the trishear zones can be used to predict fracture orientations throughout the structures (Figure 13) (Allmendinger, 1998).

Erslev (1991) notes that trishear deformation suggests several possible trajectories of fault-propagation, where zones of maximum shear and bed thinning extend from the fault tips and may guide fault-propagation trajectories. Trishear in front of thrust faults can cause relatively minor extension in the hanging wall anticline relative to the thickening in the footwall syncline. Thickening of ductile units in synclines has been observed in many thrust belts and in experiments (Erslev, 1991). 


\section{Faulted Detachment Folds}

A third possible explanation, although less reasonable, of the structure seen in the study area is a faulted detachment fold. Folding prior to thrust-sheet emplacement has been proposed to explain the presence of overturned synclines in the footwalls of many thrust faults within the Appalachian foreland fold and thrust belt of southwest Virginia (Stanley, 1983). Stanley continues to state that "mesocopic fabric data and strain states indicate rotation of bedding by folding prior to thrust sheet emplacement rather than drag folding during thrusting."

In contrast, Mitra (2002) states that because faulted detachment folds superficially resemble fault-propagation folds, their geometry can be misinterpreted in areas of poor data quality. Mitra continues to state that characteristic features for distinguishing faulted detachment folds from fault-propagation folds includes fold-fault relationships indicating a transition from folding to faulting, such as footwall synclines and decapitated fold geometries. Fault-tip folds are characterized by blind thrusts, which terminate up section by transferring slip to an asymmetric fold forming at its tip. These structures are recognized as an important structural style in several fold belts, including in the Central Appalachian Valley and Ridge (Mitra, 2002).

Faulted detachment folds form by a transition in deformational behavior from detachment folding to progressive fault-propagation (Figure 14) (Mitra, 2002). Detachment folds form in sedimentary units characterized by significant thickness and competency contrasts (Mitra, 2002). Mitra (2002) proposed that there are two types of faulted detachment folds, which he terms Model 1 and Model 2. Model 1 faulted detachment folds involves three key elements. These elements include: a relatively thin 
incompetent unit at the base, which deforms by ductile flow, overlain by a thick sequence of competent units, which deform by flexural-slip folding, accompanied by fracturing and faulting, and a thin layer of moderately competent units, which undergoes some deformation. Model 2 assumes a mechanical stratigraphy consisting of three key elements. These three elements include (from bottom to top); a thick incompetent basal unit that undergoes significant heterogeneous deformation, a moderately competent unit with a high flexural-slip, and an upper, moderately thick, incompetent unit that undergoes some amount of deformation within deformation zones.

Wiltschko and Chapple (1977) proposed for the Appalachian Plateau that within asymmetric faulted detachment folds all units sink below their regional levels within the synclines and rise within the anticlines. The extent of the synclinal downwarping depends on the ductility of the basal unit. A moderately competent basal unit generally results in less synclinal deflection, where as an incompetent basal unit results in more significant deflection (Mitra, 2002). Minor regional downwarping within the syncline has been observed with the study area, as the detachment is located within a more competent unit. 
(a)

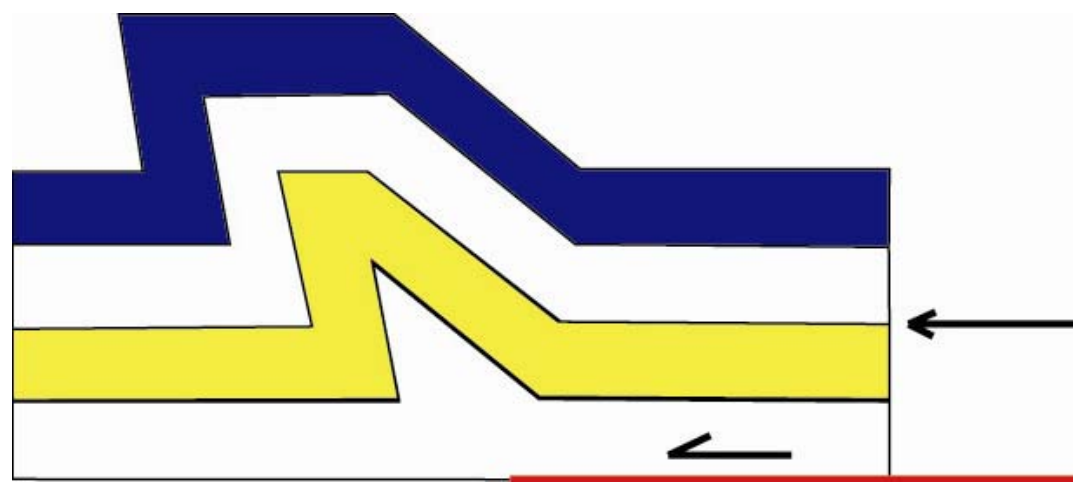

(b)

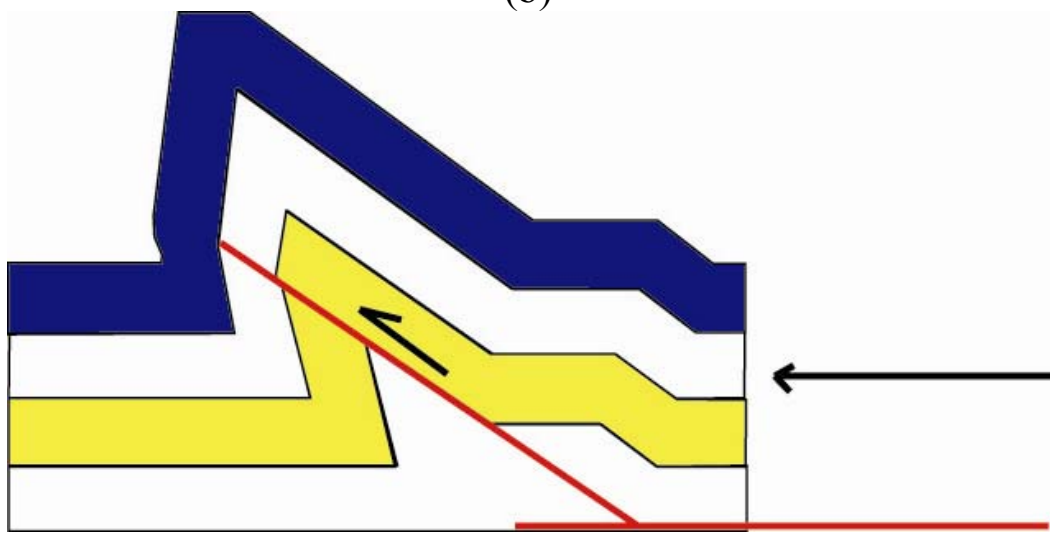

Figure 14: Diagram showing the evolution of a detachment fold. (a) Shows the initial step of detachment folding, where no faulting has occurred. (b) Shows second step of detachment folding, where after folding has began, the fault then propagates through the strata (Modified from Kattenhorn, 1994). 


\section{Table 1: Comparison of Fault-Related Fold Styles (From Giffels, 2002)}

\begin{tabular}{|c|c|c|c|}
\hline Fold Model & $\begin{array}{l}\text { Geometric } \\
\text { Characteristics }\end{array}$ & $\begin{array}{l}\text { Rheological } \\
\text { Characteristics }\end{array}$ & Strain Distribution \\
\hline $\begin{array}{l}\text { Fault- } \\
\text { Propagation } \\
\text { Fold }\end{array}$ & $\begin{array}{l}\text { Limb thicknesses can be } \\
\text { different in forelimb and back } \\
\text { limb } \\
\text { Angular fold shape } \\
\text { Footwall strata are not folded } \\
\text { A fault ramp is located in front } \\
\text { of the forelimb, or underneath } \\
\text { the fold core } \\
\text { Interlimb angles usually range } \\
\text { from medium( } 60-120 \text { degrees) } \\
\text { to small (<60 degrees) }\end{array}$ & $\begin{array}{l}\text { Small mechanical strength } \\
\text { difference between units } \\
\text { involved }\end{array}$ & $\begin{array}{l}\text { Moderate deformation of units in } \\
\text { forelimb } \\
\text { Strain axes orientations are the same } \\
\text { at the top of the forelimb and at the } \\
\text { bottom of forelimb } \\
\text { Strain is the result of flexural slip }\end{array}$ \\
\hline Trishear & $\begin{array}{l}\text { Limb thicknesses are different } \\
\text { in forelimb and back limb } \\
\text { Rounded to angular fold shape } \\
\text { Footwall strata may be folded } \\
\text { Forelimb thickness changes } \\
\text { with depth } \\
\text { A fault ramp is located in front } \\
\text { of the forelimb, or underneath } \\
\text { the fold core }\end{array}$ & $\begin{array}{l}\text { Small mechanical strength } \\
\text { difference between units } \\
\text { involved }\end{array}$ & $\begin{array}{l}\text { Moderate deformation of units in } \\
\text { forelimb } \\
\text { Strain axes orientations change from } \\
\text { the top to the bottom of forelimb } \\
\text { Strain is the result of penetrative } \\
\text { trishear }\end{array}$ \\
\hline $\begin{array}{l}\text { Detachment } \\
\text { Fold }\end{array}$ & $\begin{array}{l}\text { Limb thicknesses are the same } \\
\text { in forelimb and backlimb } \\
\text { The underlying detachment is } \\
\text { flat } \\
\text { Interlimb angles can range } \\
\text { from small ( }<60 \text { degrees) to } \\
\text { large ( }>120 \text { degrees) } \\
\text { Fold wavelength is determined } \\
\text { by thickness of the } \\
\text { mechanically most competent } \\
\text { unit }\end{array}$ & $\begin{array}{l}\text { Decollement is contained in a } \\
\text { relatively ductile unit that is } \\
\text { overlain by a mechanically } \\
\text { stronger unit }\end{array}$ & $\begin{array}{l}\text { Disharmonic folding and thickening } \\
\text { in anticline core with more parallel } \\
\text { bedding preserved toward outside of } \\
\text { the fold }\end{array}$ \\
\hline
\end{tabular}




\section{Chapter 5: Previous Work}

A previous geologic map was completed in 1926 by Reger et al. which encompassed Monroe County, WV. This geologic map provided useful insight to the geology of the study area. In their map, they provide three cross-sections, two of which are on either side of the study area. This map was used as a base for the field mapping, helping fill in areas of poor exposure and areas that were not accessible.

Several studies have been conducted on the St. Clair thrust fault. In 1982, Thomas K. Gustafson wrote a paper titled, “Geology and Structural Analysis between the Narrows and St. Clair thrust faults in the Narrows Quadrangle, Giles County, Virginia." In his paper, Gustafson states that the structures associated with the hanging wall of the St. Clair fault involve the Upper Cambrian Knox Dolomite [Beekmantown] through the Lower Mississippian Sandstones of the Price Formation. He indicates that the footwall of the St. Clair fault ranges from the Upper Ordovician Juniata Formation to the Lower Pennsylvanian Lee Formation within the Hurricane Ridge syncline. Gustafson also notes that the St. Clair can be easily delineated by the easily distinguishable lower section of the Knox Group on the hanging wall and the deformed shale and siltstone of the Devonian Chemung Formation on the footwall.

Another paper that involves the St. Clair fault was written by Andrew Leigh Mehlhop in 1996 titled, "Extensional Structures along the Allegheny Front in Virginia and West Virginia near the Giles County seismic zone.” Mehlhops' study focused on the structures that are exposed in the footwall of the St. Clair thrust fault. In his paper Mehlhop provides several useful figures, including a schematic block diagram that illustrates the major structures in his study area, a generalized stratigraphic column, 
detailed lithologic descriptions, and a cross-section of his study area. Although the St. Clair fault is not an extensional structure, the figures presented by Mehlhop (1996) are helpful in understanding the stratigraphy and structure within the study area. Mehlhop (1996) is more concerned with the Lindside Fault Zone than he is with the St. Clair fault. The structures of the Lindside Fault Zone are important to this study as these structures relate to the strain that is present in the footwall. These footwall structures are the same structures that are trying to be explained by using trishear deformation.

Kulander and Dean (1988) examined a series of thrust faults just south of the map area, namely the North Mountain-Pulaski fault system. They note the Blue Ridge and Great Valley of western Virginia are part of a detached master thrust sheet that extends through the central-southern Appalachian change of trend and has a root zone situated east of the Blue Ridge under the Piedmont (Figure 9). They have suggested that, just like the St. Clair thrust in the map area, displacement on the Pulaski fault increases from northeast to southwest (or as stated earlier, decrease from southwest to northeast) (Kulander and Dean, 1988). One significant problem with the work of Kulander and Dean is that the series of cross sections they created were not balanced before being analyzed. The transition from the central Appalachian structural grain of N30E to the southern Appalachian structural trend of N60E occurs within the V-shaped Roanoke Recess north of Roanoke, V.A. It is at this location where thrusts such as the Saltville and St. Clair faults that characterize the structural style of the southern Appalachians terminate, and sedimentary rock cover shortening is increasingly accommodated by folding in the central Appalachians (Kulander and Dean, 1988). The evidence of this 
occurring is the presence of increased fold frequency and widening of the fold belt to the northeast (Kulander and Dean, 1988).

Spaggins and Dunne (2002) indicate that within the Appalachians, emergent thrusts give way to map-scale folds above blind duplexes. Within the study area, it has been observed that the Narrows thrust fault transferred its strain from faulting to folding, creating the Fork Mountain Anticline. Within their article, the authors provide a regional map showing the locations of the central and southern Appalachians, the St. Clair thrust fault, and the Wills Mountain Anticline (Figure 15). Three sequential cross-sections are also provided, each giving insight to the nature of the St. Clair thrust fault. The authors state that the Appalachian Plateau in the recess was an area of active blind thrusting during the late Paleozoic formation of the Appalachian portion of the Alleghenian thrust belt (Figure 16c). They provide two possible explanations for the St. Clair thrust fault.

The first is that displacement from the southern Appalachian portion of the Alleghenian thrust belt was not substantially transferred into the Appalachian Plateau. Therefore, up to $20 \mathrm{~km}$ of thrust displacement for the southern Appalachian St. Clair thrust sheet emerges through the surface trace of the St. Clair thrust in front of the plateau (Figure 16a) (Spraggins and Dunne, 2002). A second hypothesis provided by Spraggins and Dunne (2002) is that the St. Clair thrust is only an imbricate fault of a blind thrust flat, which continues into the Appalachian Plateau (Figure 16b). Finally, they state that the St. Clair thrust fault terminates in a regional anticline at the junction of the southern and central Appalachians (Figure 16c). Couzens and Dunne (1994) suggest that this termination is the result of displacement transfer to a blind thrust instead of simply a displacement decrease to zero for an emergent thrust (Spraggins and Dunne, 2002). 
Their conclusion is that the existence of a blind fault supports an interpretation that the St. Clair thrust sheet and the Wills Mountain duplex are a continuous structure (Spraggins and Dunne, 2002). 


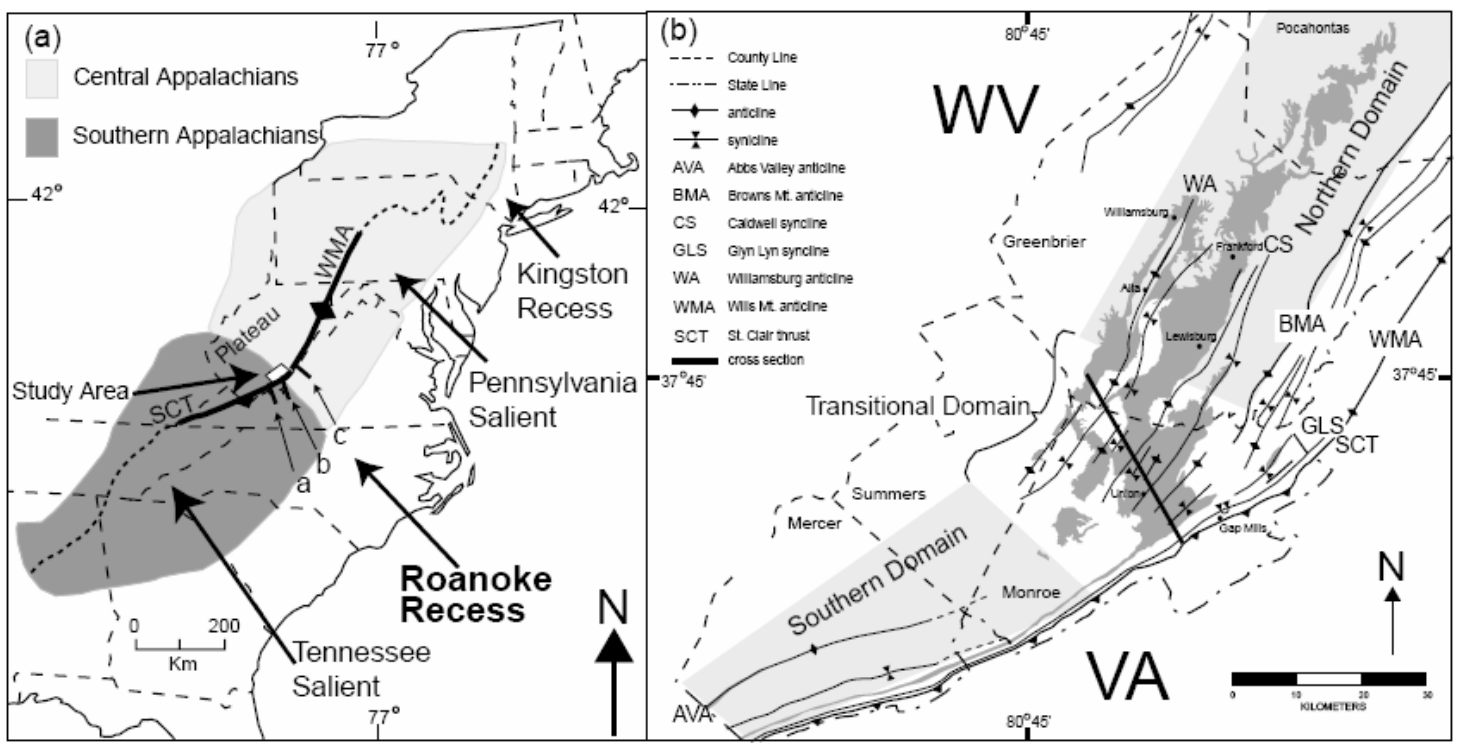

Figure 15: (a) Map showing the locations of the Central and Southern Appalachians, St. Clair thrust, Wills Mountain Anticline, and other structural elements. Letters a, b, and c represent locations of sequential cross sections (shown in Figure 16). (b) Map showing close-up of study area. (Spraggins and Dunne, 2002)

(a)

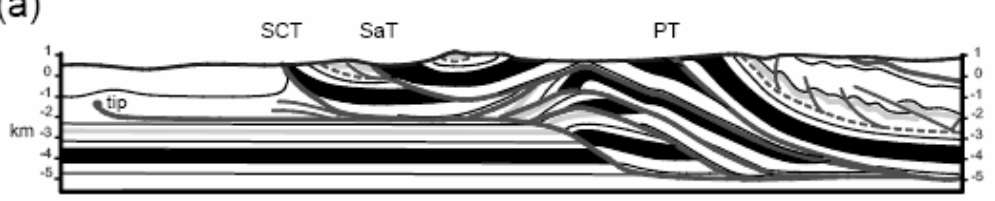

(b)

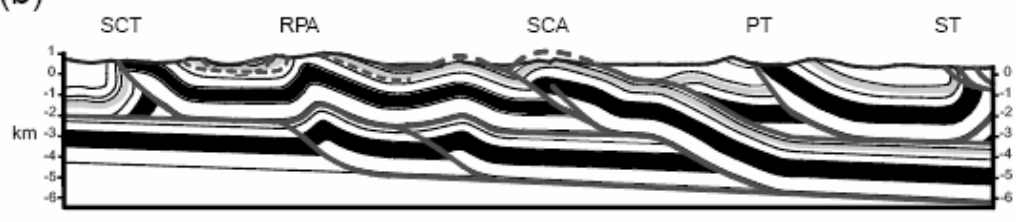

(c)

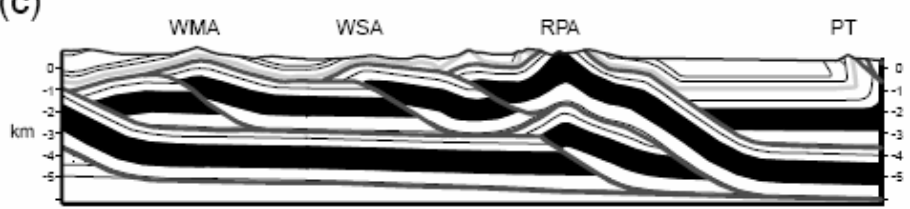

Figure 16: Sequential cross sections along the St. Clair thrust fault. Locations of cross sections indicated in Figure 15. It is important to note that in (a) and (b) the St. Clair thrust fault breaches the present-day surface. In cross section (c), the St. Clair thrust fault does not reach the surface. Faulting has been transferred to folding. SCT-St. Clair thrust, WMA - Wills Mountain Anticline. (Spraggins and Dunne, 2002). 


\section{Chapter 6: Surface Research}

\section{Background Information}

The St. Clair fault has been geologically mapped at a scale of 1:24,000 as per EDMAP requirements in Monroe County, West Virginia (at total area of $12 \times 16 \mathrm{~km}$, Figure 2). The mapping has encompassed most of the Gap Mills Quadrangle and small portions of the Union, Waiteville and Interior Quadrangles. The geological map was then transferred into a shapefile for use in GIS applications. This was done using the ArcGIS software package. As noted before, this strain information has been used to estimate the fracture density along the fault and to potentially be used to predict possible targets for natural gas production. The strain distribution along the fault has been estimated by utilizing Allmendinger's Fault/Fold software package, which provides strain ellipses for strata within the triangular zone of a fault.

As noted above, Midland Valley, Inc.'s 2D move software has been used to analyze the data. To use 2D move, the user first imports his/her data, then through model conditioning and jigsaw restoration, can utilize kinematic restoration and analysis to create a final structural model. The final structural model can then be subjected to forward modeling and analysis, which includes fracture prediction, kinematic analysis, and volume analysis, to create a present day structural architecture (Figure 17). 


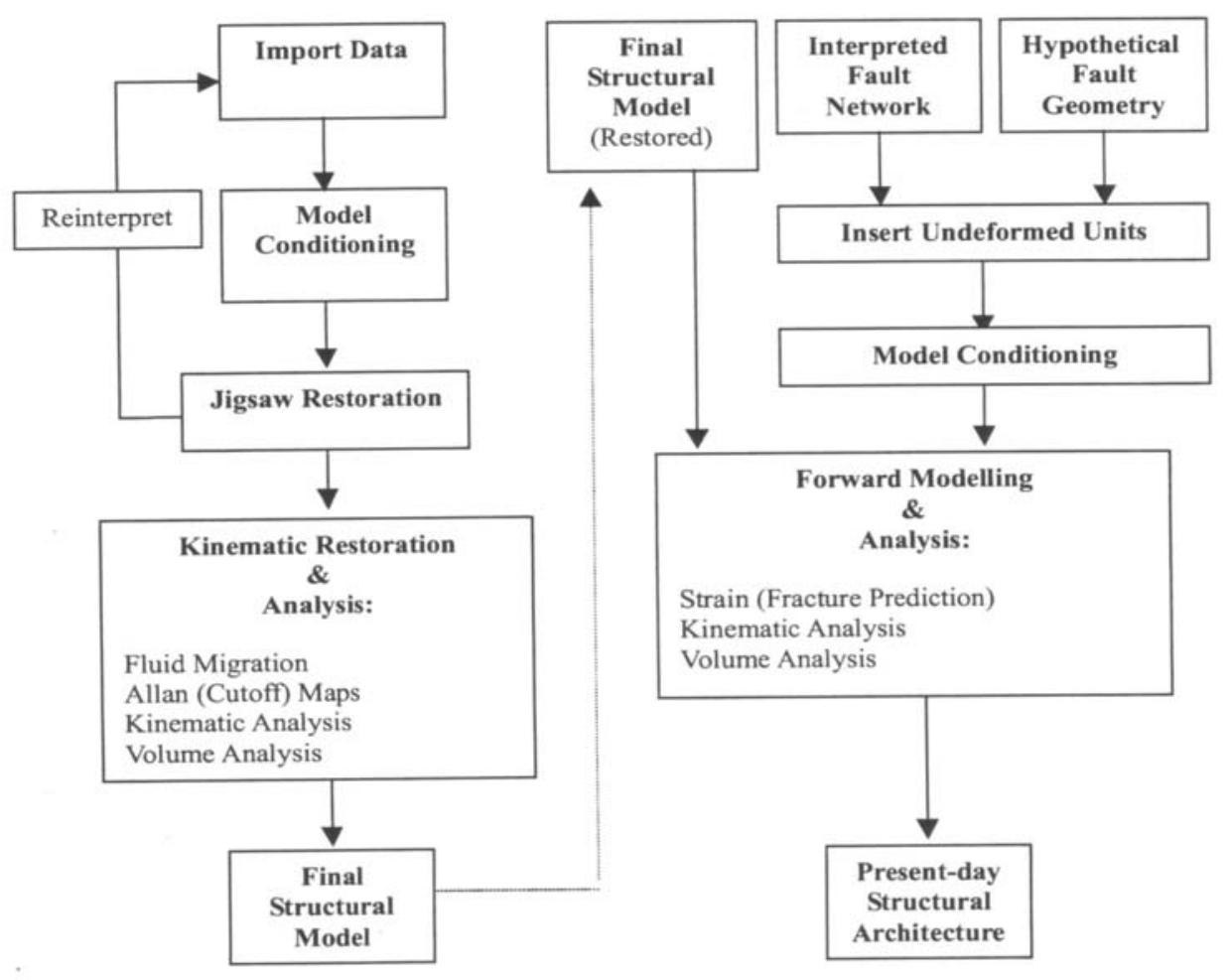

Figure 17: Flow chart for the kinematic modeling software, 2D Move (From 2DMove manual). 


\section{Surficial Mapping and Modeling}

Data for this project has been collected solely through surficial observations; no seismic or well data were available for use. In conjunction with these surficial observations, several items have been noted. These include: strike and dip data, UTM locations for data points, formation descriptions (which includes lithologies), and hand samples of the formations that are to be described (Appendix I). Observations were taken and mapped using the Universal Transverse Mercator 1927, Zone 17, North American Datum (NAD 27). The collected data were used to create a geologic map and three subsequent cross-sections. To aid in the field mapping, aerial photographs were used.

The geologic map was initially created on hard copies of the topographic maps by transferring the observed data onto them, which includes locations of each data point and strike and dip data. The geologic map was then traced onto a clear Mylar paper and scanned to create an image file for each quadrangle. These image files were imported into the ESRI ArcGIS software package and georeferenced for future use.

Georeferencing allows data to be viewed, queried, and analyzed with other geographic data. Once the images were imported into the ArcGIS software package, the contacts were converted into an ArcGIS shapefile. This was done using Arc and ArcCatalog. Using ArcCatalog, the images were exported to a coverage. Then Arc was used to build, clean, and describe the coverages. Once the coverages were created, ArcCatalog was once again used to convert the coverage into a single shapefile. 
Then using the editor option within ArcGIS, it was possible to make minor adjustments within the shapefile, such as closing small holes and removing any unwanted marks. The contacts were then closed in using a neatline, which is a border that is drawn to delineate and define the extent of geographic data on a map. The neatline allowed each formation to be designated a specific color. This shapefile was then draped over the 3-meter digital elevation model to provide topography to the map. Also added to the map were folds, faults, major and minor roads, streams, and strike and dip markers. The completed map can be seen in Figure 18. 


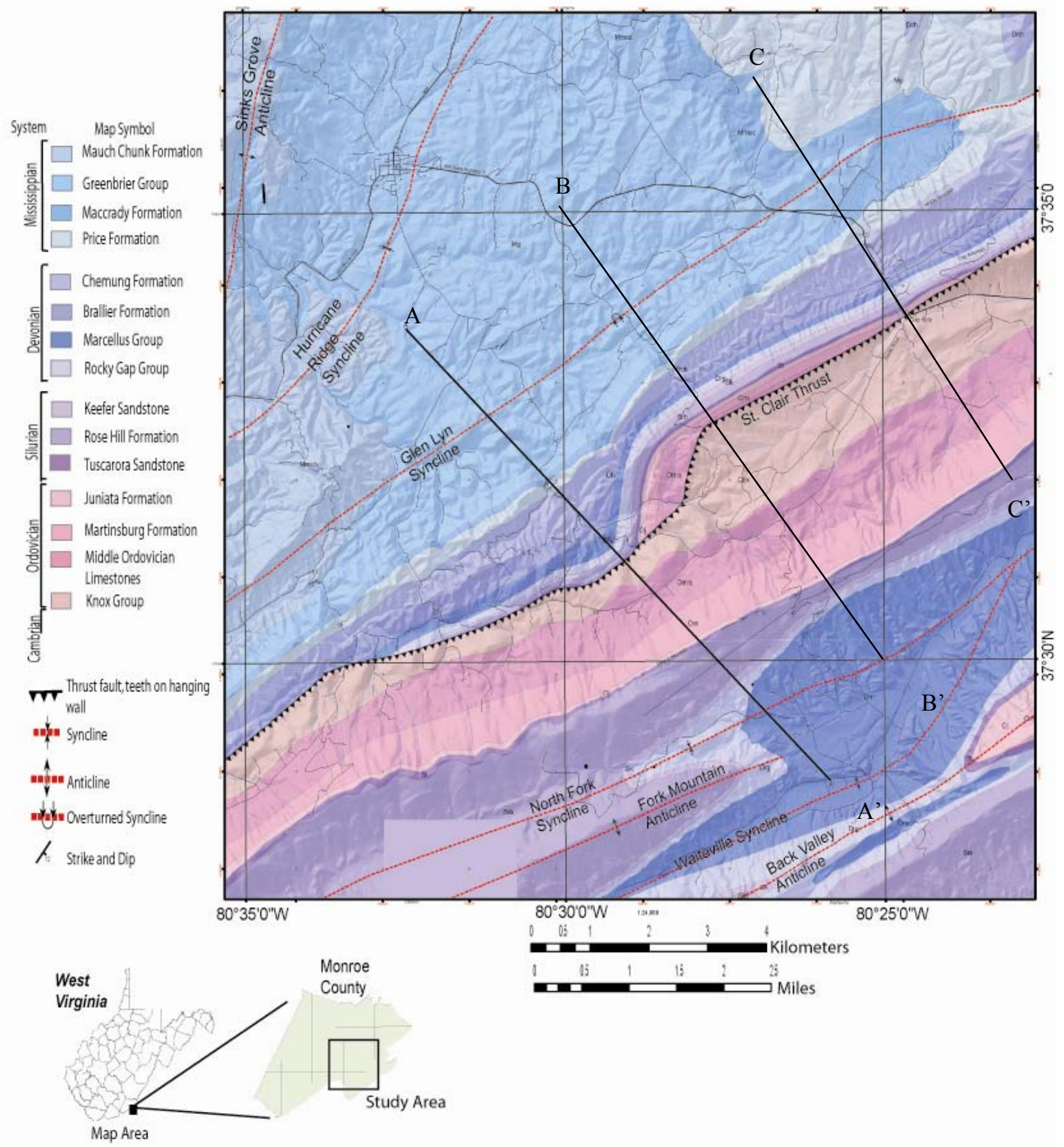

Figure 18: Completed geologic map of the study area. St. Clair thrust fault and other major folds are labeled. Lines of cross section are shown as A-A' on map. Corresponding crosssections are shown in Figure 19. 


\section{Cross-sections:}

To aid in the creation of the sequential cross-sections, the topographic profiles were created using a 3 meter digital elevation model (DEM) and the ArcGIS software suite. This was done by opening the 3-meter DEM of the area and also opening the 3D Analyst extension with ArcMap. Then the correct DEM layer was selected and the interpolate line function was selected. Two endpoints were then located and marked in the DEM. Finally, the histogram button was selected to create the profile. The 3 meter DEM files were obtained from the West Virginia GIS Technical Center. The created topographic profiles were then imported into Adobe Illustrator and were adjusted to be on a 1:1 scale.

Once the sequential cross-sections had been created, it was necessary to check the validity of these cross-sections, that is, checking for geometric acceptability. This has been done through a process known as balancing a cross-section. To obtain a balanced cross-section, one flattens out the deformed beds and returns them to their depositional position. If this restoration can be completed, it is possible to conclude that the crosssection is geometrically feasible (Dahlstrom, 1969). Dahlstrom continues to state that, "It should be emphasized that a cross-section which passes the geometric tests is not necessarily correct, because completely ridiculous cross sections can be drawn which abide the law of conservation of volume. However, if a cross-section passes the geometric tests, it could be correct... and on the other hand a cross-section that does not pass the geometric tests could not possibly be correct" (Dahlstrom, 1969).

It is important to assure that the completed cross-sections are balanced, as the quality of structural cross-sections can be improved by testing them for geometric 
validity (Dahlstrom, 1969). Balanced cross-sections provide a powerful constraint in the interpretation of complex structures characterized by poor data quality. Fold and thrust belts are characterized by complex structures, so available surface data is usually poor quality (Mitra, 1992). Balanced cross-sections provide a link between the deformed and undeformed states.

The cross-sections have been analyzed using Midland Valley, Inc.'s 2DMove software. As noted in the 2DMove manual, "2DMove is a structural analysis and modeling program that allows line-length and area balancing of cross-sections." Both structural restorations and forward modeling can be carried out with 2DMove. The 2DMove software is capable of balancing cross-sections, providing strain data (fracture prediction), kinematic analysis, and volume analysis as well as other information. 2DMove also includes kinematic models for trishear deformation and for fault-parallel flow. It is necessary to incorporate both trishear deformation and fault-parallel flow to model the hanging wall and footwall of the St. Clair fault.

In order to recreate the cross-sections, it was necessary to incorporate a step in the fault. In cross-section A-A', the St. Clair thrust fault is located at the base of the Martinsburg Formation (Figure 19a). For the other cross-sections, the St. Clair thrust fault needed to step down into lower stratigraphic units to allow the presence of the Middle Ordovician Limestone in the footwall (Figures 19b and c). Completed sequential cross-sections are located in Figure 19 as well as in a pouch at the back. 
(a)

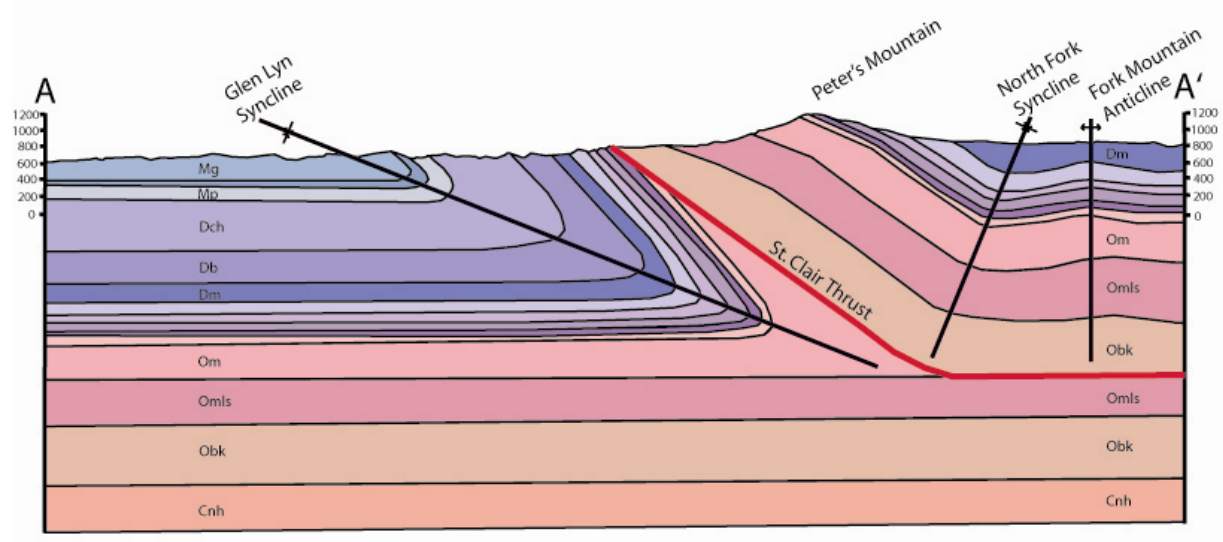

(b)

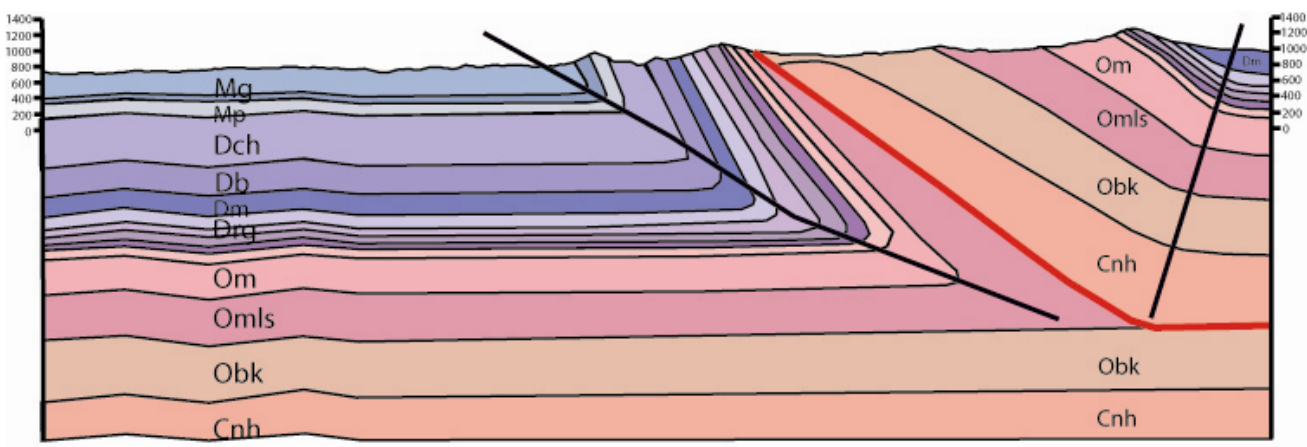

(c)

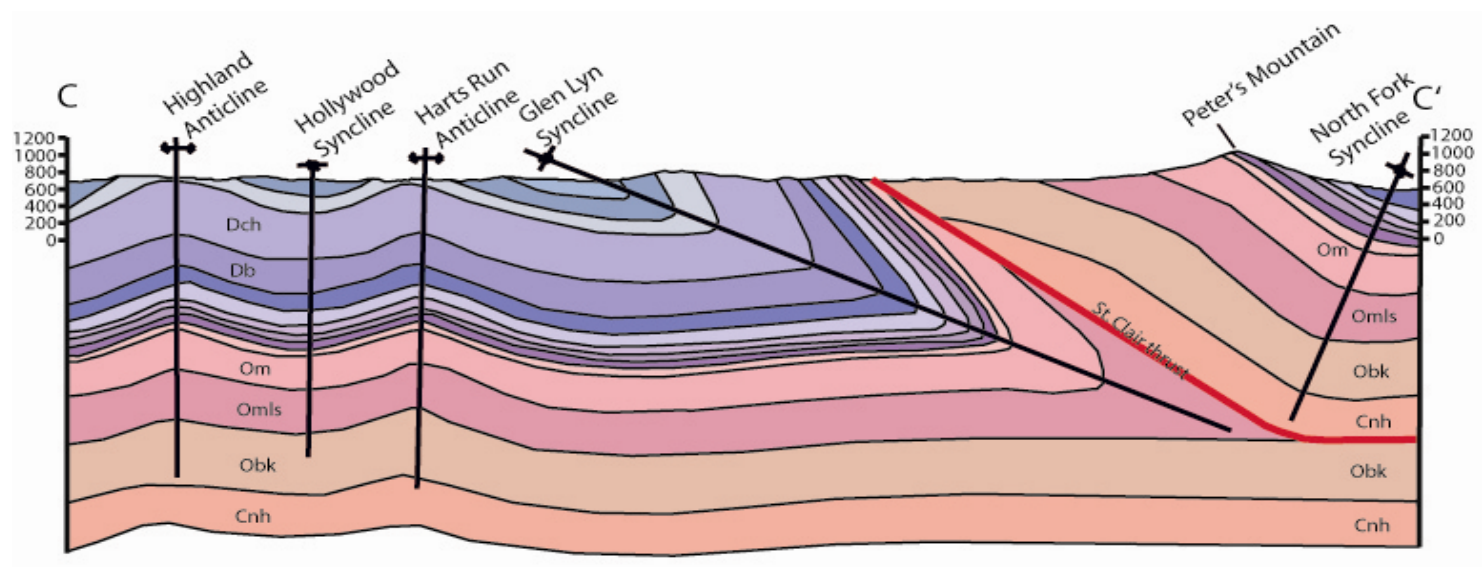

$0 \quad 1000 \quad 2000 \quad 3000$ Feet

$0 \quad \dot{500 \quad 1000 ~ M e t e r s ~}$

Figure 19: Sequential cross-sections across the study area. Lines of cross-sections are shown on figure 18. 


\section{Chapter 7: Interpretations from Computer Modeling}

It has become apparent that the structures that are associated with the St. Clair thrust fault have formed through a combination of processes. Through examination of the observed field data and the modeled cross-sections, it has been possible to rule out the idea that the St. Clair thrust fault formed as a result of a faulted detachment fold. With faulted detachment folding, there is no change in thickness between the forelimb and backlimb. Observations and modeling support the idea that there is a significant thickness change along the overturned footwall syncline. It has been interpreted that the St. Clair thrust fault has formed by a combination of fault-bend folding and trishear deformation. It is important to understand how each parameter affects the overall structure being formed. Therefore, the various parameters were adjusted individually, to find the effects of each parameter. These parameters include the propagation to slip ratio (P:S ratio) of the fault, the trishear apex angle, angular shear, the trishear angle, and the number of trishear zones.

\section{Propagation-to-Slip Ratio}

Unlike parallel-kink fault-propagation, which uses a fixed propagation-to-slip ratio based of fault geometry, trishear allows great flexibility in the choice of the propagation-to-slip ratio. With trishear, it is possible to specify any propagation-to-slip ratio for any fault geometry (Allmendinger et al., 2004). The P:S ratio describes how much the fault propagates through the strata as displacement is added. A change in the $\mathrm{P}: \mathrm{S}$ ratio of just 0.3 produces a change in fold shape that is equivalent to that produced by a $15-20^{\circ}$ change in trishear angle (Allmendinger, et al., 2004). The Propagation-to-slip ratio exerts the most important control on the amount of strain in a trishear structure. The 
lower the P:S ratio is, the more opportunity the ductile layers will have to deform (Allmendinger et al., 2004).

If a P:S ratio of zero is used the fault does not propagate into the overlying strata as displacement is added. A P:S ratio of 0.5 depicts that the fault is propagating forward half as much as the fault displacement. Likewise, a P:S ratio of 1.0 indicates that the fault is propagating forward as much as the fault displacement. The geometry of the resulting fold changes significantly as the $\mathrm{P}: \mathrm{S}$ ratio is increased. A small P:S ratio results in an overturned syncline and anticline pair. The footwall syncline in a small P:S ratio fold displays thickening of the strata as they are folded and thinning as they overturn. When a small P:S ratio is used, more deformation occurs on the forelimb. When a larger $\mathrm{P}: \mathrm{S}$ ratio is used, the thickening of the strata as they fold is still present, but instead of thinning as they overturn, the strata are cut by the propagating fault. Diagrams showing the affects of changing P:S ratios are shown in Figure 20.

It has been found that the difference between a detachment fold, a fault-bend fold and a trishear fault-propagation fold lies within the propagation-to-slip ratio. A propagation-to-slip ratio of zero indicated the development of a detachment fold (Figure 21a). A small propagation-to-slip ratio tends to develop a trishear fault-propagation fold (Figure 21b). Finally, as the propagation-to-slip ratio increases, as shown by Allmendinger et al. (2004), the development of a fault-bend fold occurs (Figure 21c). 
(a)

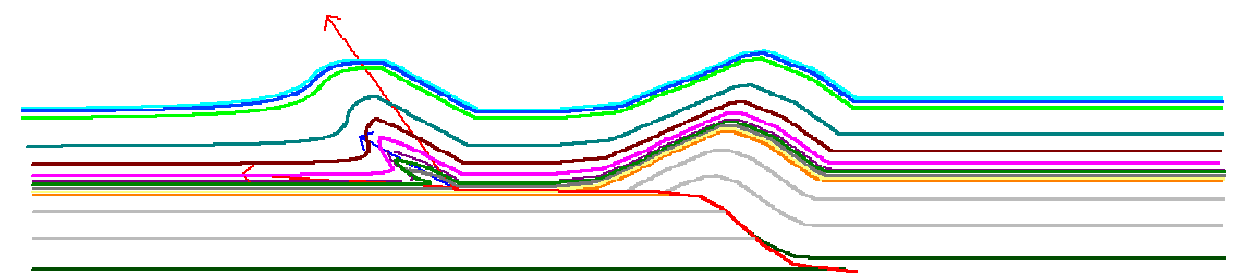

(b)

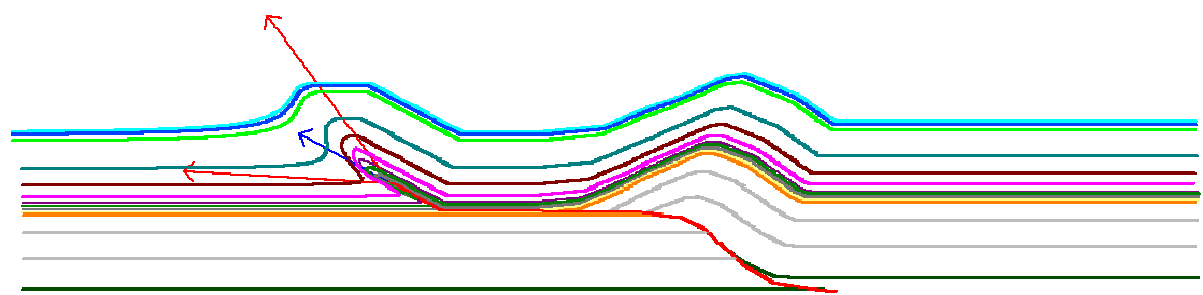

(c)

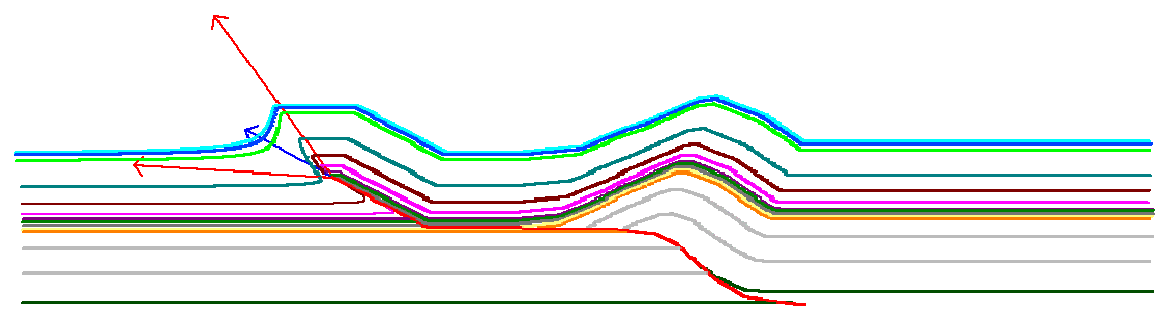

(d)

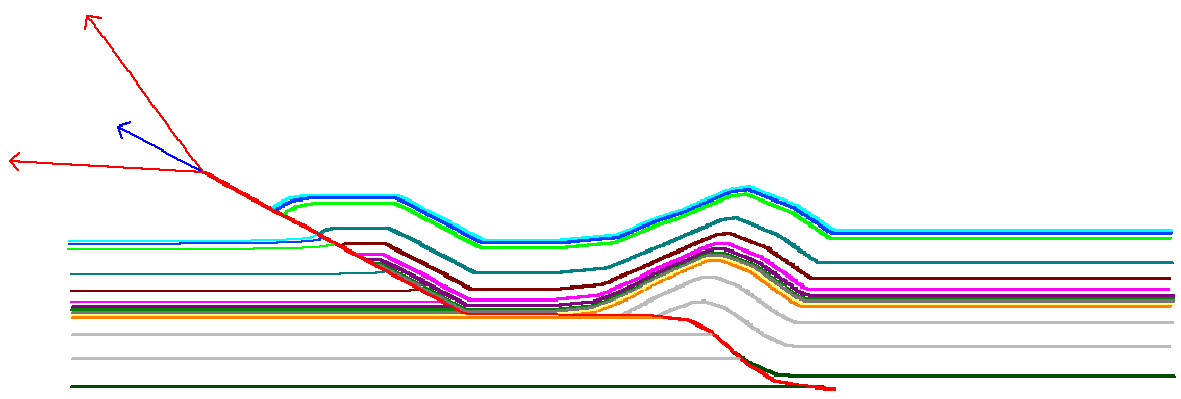

1500 Meters

Figure 20: Effects of changing propagation to slip ratio, while displacement remains constant. (a) P:S ratio of 0.0 , note that the fault does not propagate through the strata. Deformation is entirely by folding (b) P:S ratio of 0.5 , the fault begins to propagate upwards through the strata. Strata in the footwall beginning to thicken as they overturn. (c) P:S ratio of 1.0, the fault propagates through most of the layers, creating smaller folds along the fault and increased thickness changes in front of the fault. (d) P:S of 3.0, the fault has now propagated entirely through the strata. Very little folding is present. 
(a) $P: S=0$; Detachment fold

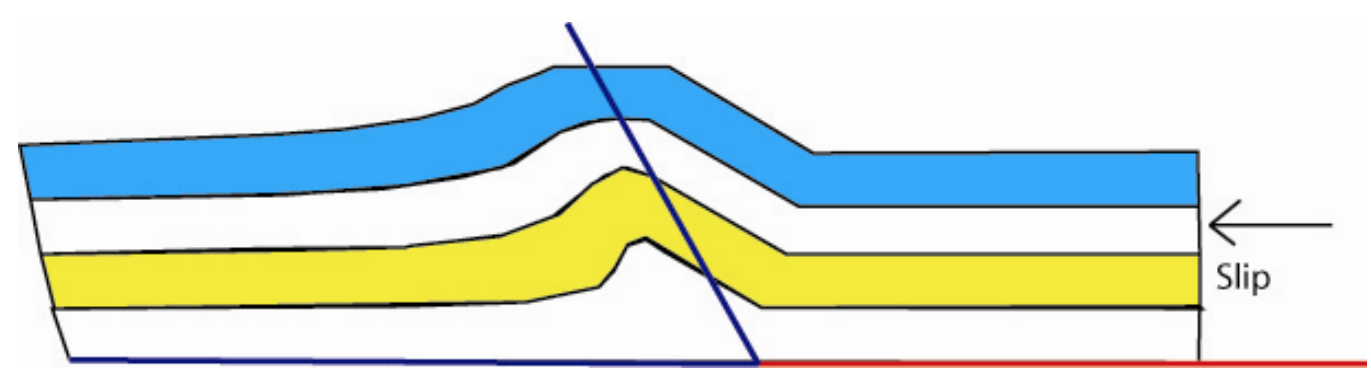

(b) $\mathrm{P}: \mathrm{S}=1.5$; Trishear fault-propagation fold

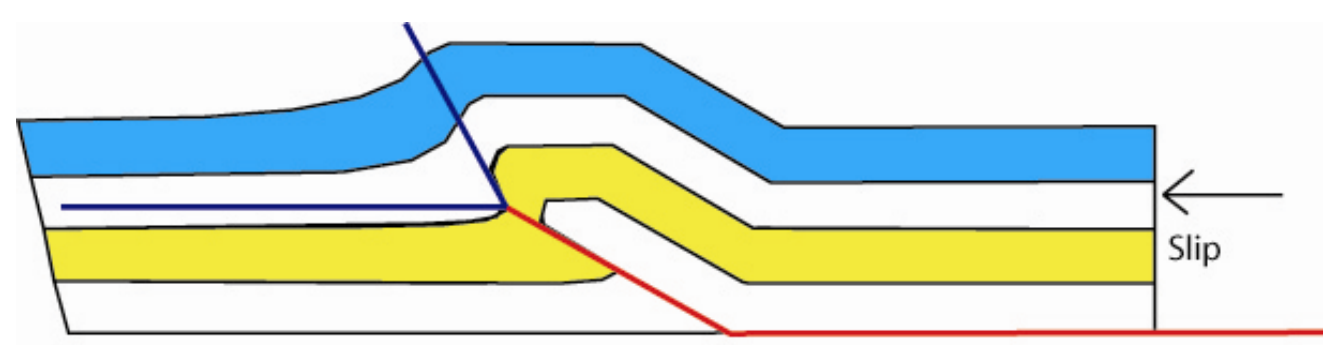

(c) $P: S=15$; Fault-bend fold

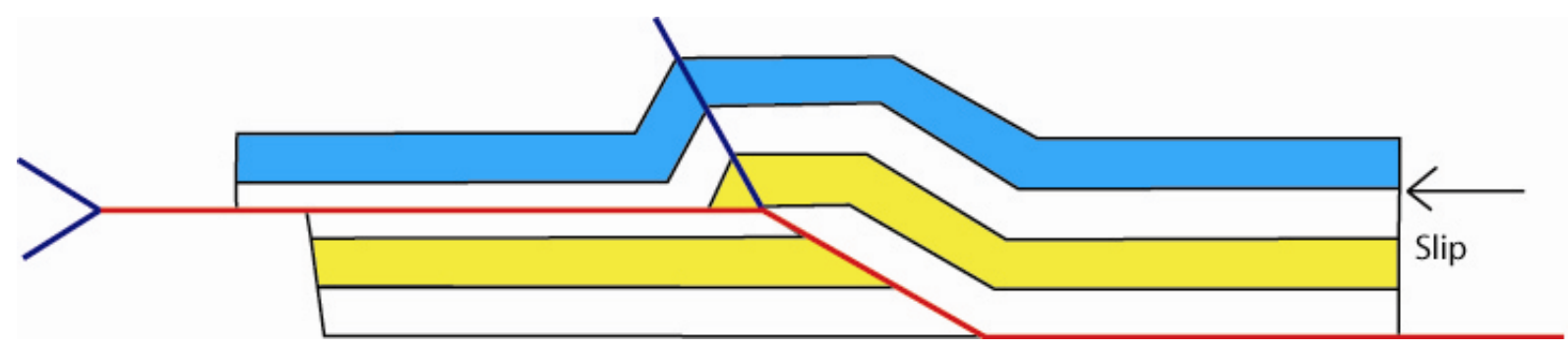

Figure 21: Diagram showing the relationship between the propagation-to-slip ratios to the type of fold that develops. The red lines represent faults; the blue lines represent the triangle zone. (a) Shows a P:S ratio of zero, which leads to the development of a detachment fold. (b) Shows a small P:S ratio, leading to the development of a trishear fault-propagation fold. (c) Shows how a large P:S ratio leads to the development of a fault-bend fold (Allmendinger et al., 2004). 


\section{Trishear Angle}

Another important factor is the trishear angle. While the entire anticline-syncline pair is getting deformed by flexural-slip-folding, the trishear zone undergoes a different type of strain. Within the triangle zone, the strata experiences inhomogeneous, distributed strain. The trishear angle directly impacts the area that is folded by the propagating fault. If the trishear angle is small, there is a small area in front of the fault that is deformed by distributed strain. On the other hand, if the angle is large, there is a large area in front of the fault that is deformed by distributed strain. Figure 22 illustrates changes in the fold geometry as the trishear angle changes.

\section{Trishear Apex Angle}

Changing the trishear apex angle changes the angle at which the fault propagates through the strata. This also greatly affects the fold geometry. A trishear apex angle of small value produces a footwall syncline, which shows little to no overturning. As the trishear apex angle increases, the footwall syncline begins to overturn. Eventually, as the apex angle reaches the vertical, the fault rapidly cuts through the strata, producing some minor folding in the footwall. The majority of the deformation here occurs as faulting. Figure 23 illustrates how changing the trishear apex angle affects the geometry of the fault and fold. 
(a)

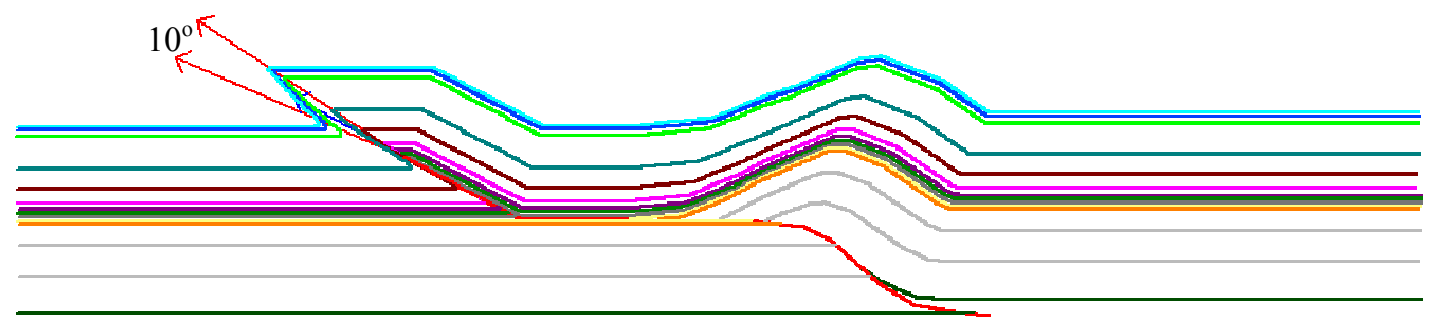

(b)

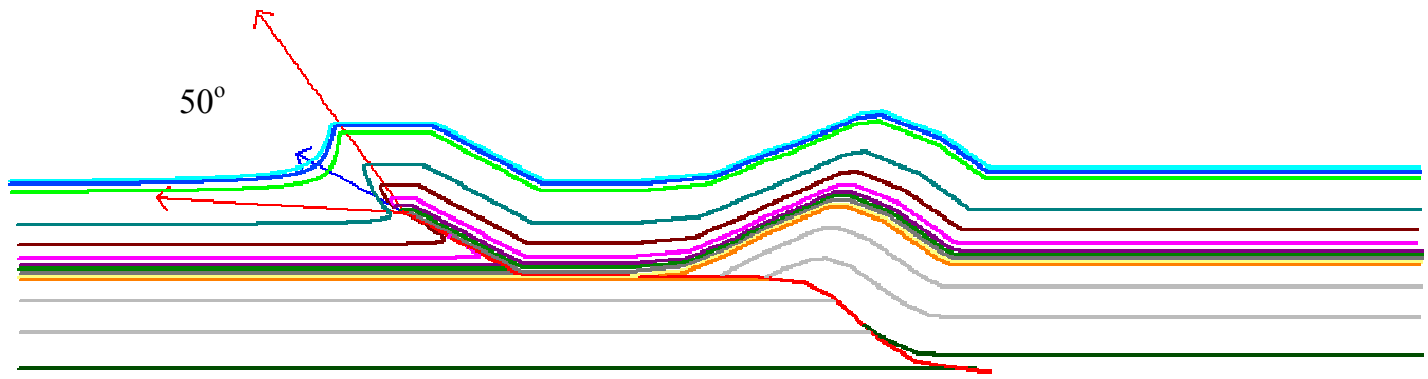

(c)

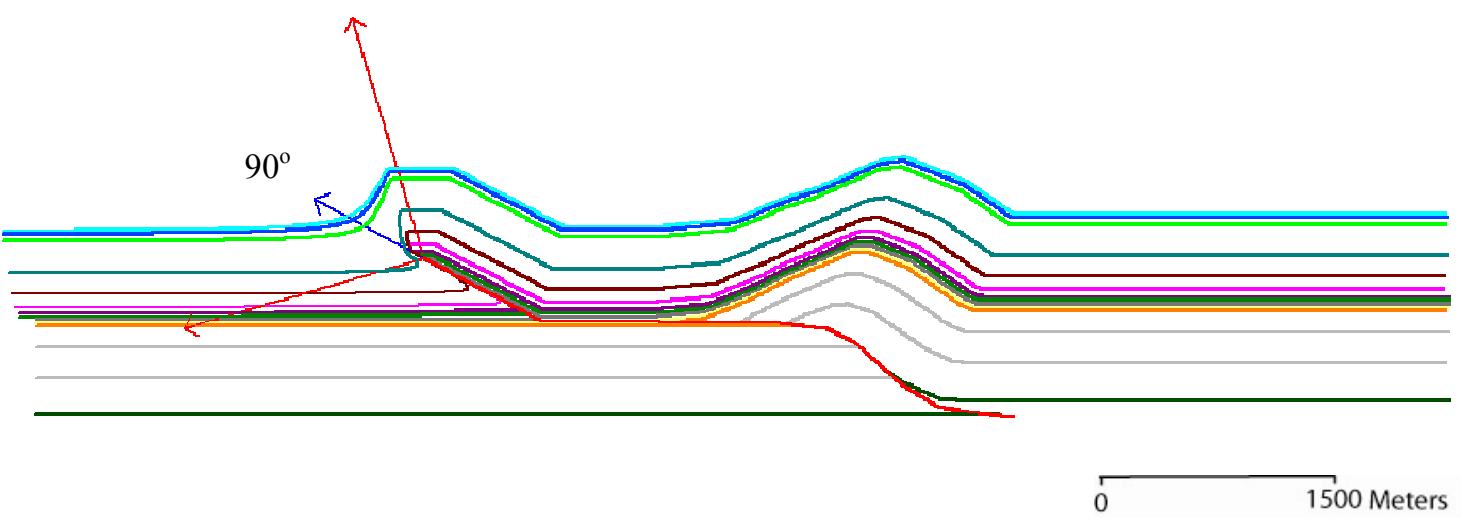

Figure 22: Diagram showing the effects of changing the trishear angle, all other variables remained constant. (a) Has a trishear angle of 10, (b) has a trishear angle of 50, and (c) has a trishear angle of 90 . The trishear angle directly impacts the area that is folded by the propagating fault. 
(a)

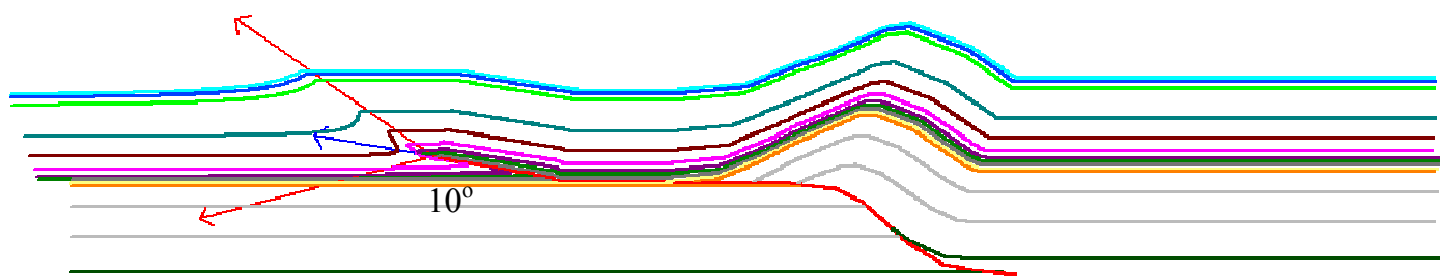

(b)

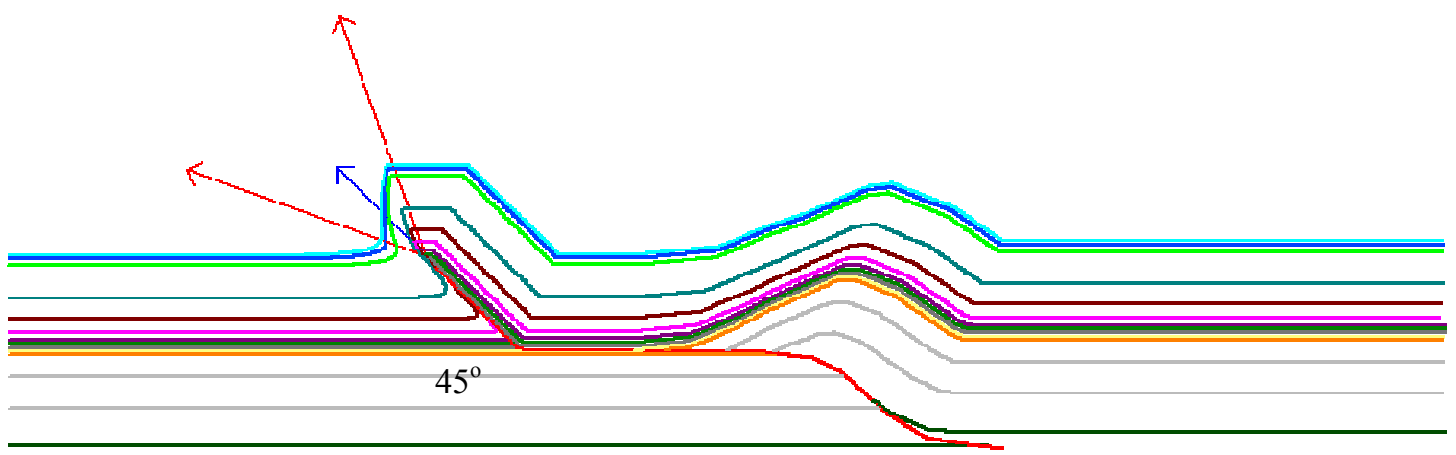

(c)

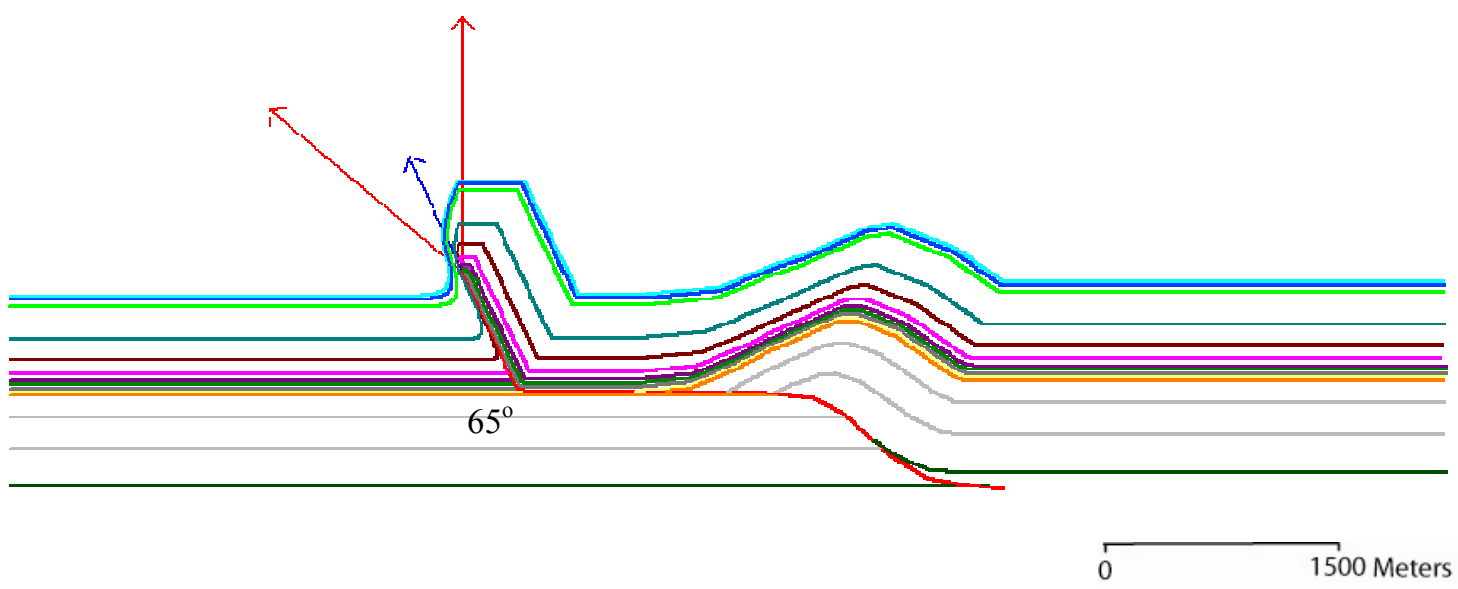

Figure 23: Diagram showing the effects of changing trishear apex angle, all other variables remained constant. Trishear Apex Angles are (a) 10, (b) 45, and (c) 65 . 


\section{Number of Trishear Zones}

The number of trishear zones used determines whether the model is deformed using homogeneous or heterogeneous trishear. During modeling, using one trishear zone indicates that the model is undergoing homogeneous trishear (Figure 24). Likewise, using a larger number indicates heterogeneous trishear. It is been found that using a larger number of zones increases the resolution of the model.

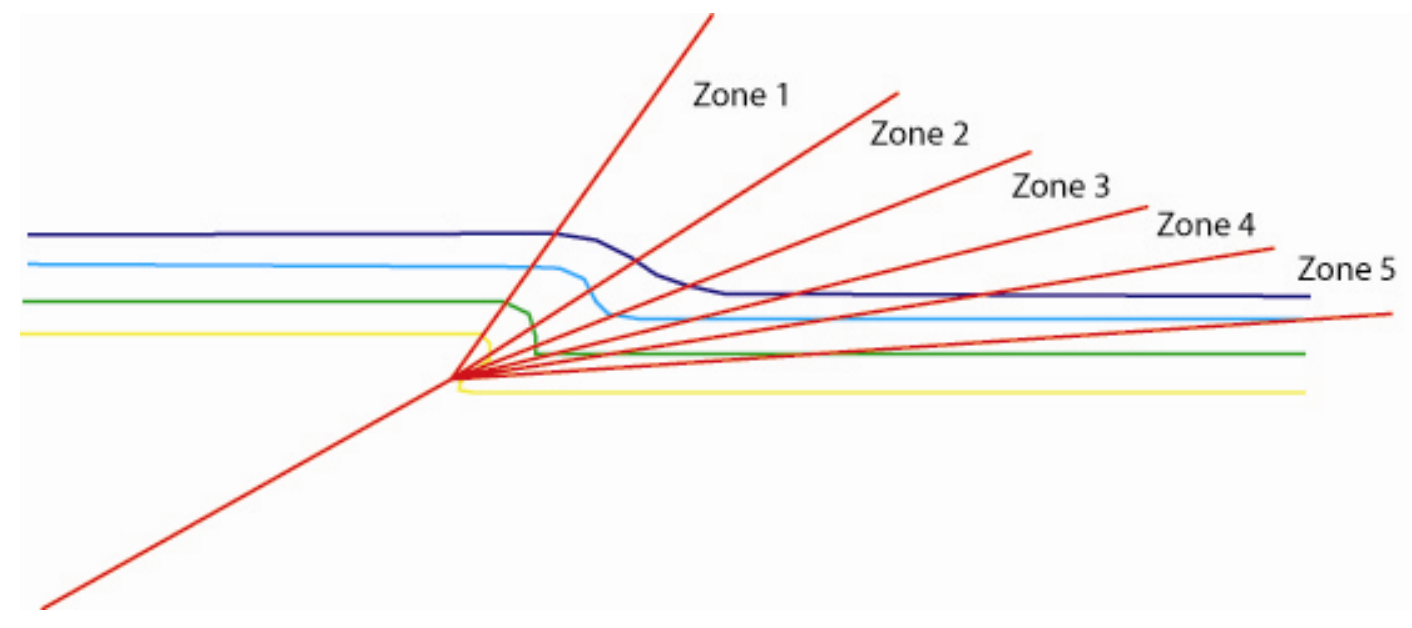

Figure 24: Diagram showing the subdivision of a single trishear zone into 5 nested zones (From Midland Valley 2DMove Help Files)

\section{Angular Shear}

Finally, changing the angular shear within the strata affects the angle at which the strata are pushed toward the fault. An angular shear of zero represents the strata being pushed evenly from the top to the bottom. Adding a positive angular shear pushes the strata more towards the bottom than the top. On the other hand, adding a negative angular shear pushes the strata more from the top than the bottom. Figure 25 illustrates how inducing angular shear into the model affects the fold geometry. It is reasonable that some combination of the above parameters will be needed to correctly model the footwall syncline. 
(a)

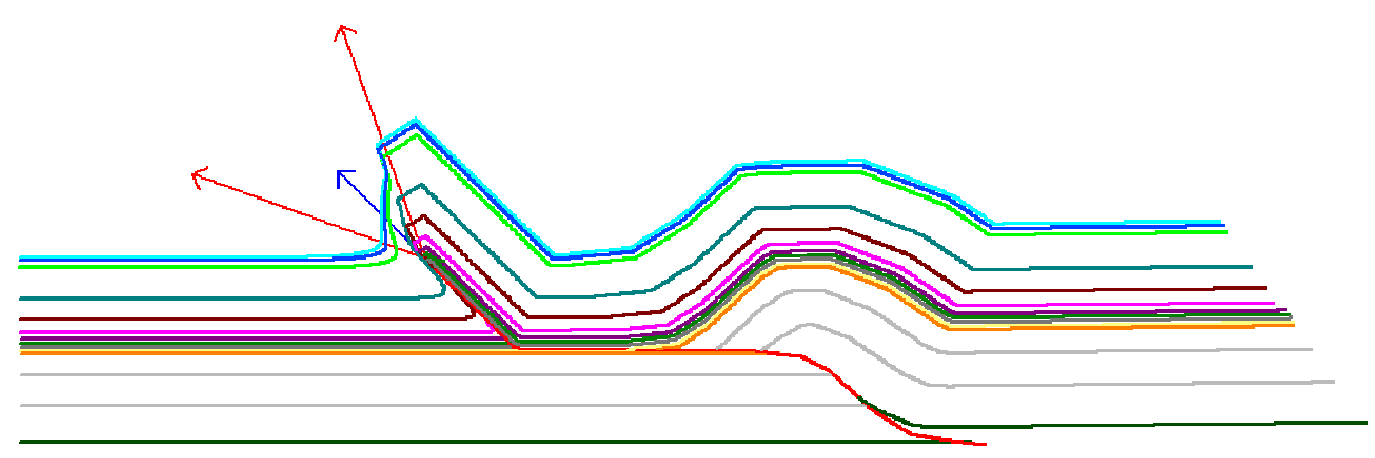

(b)

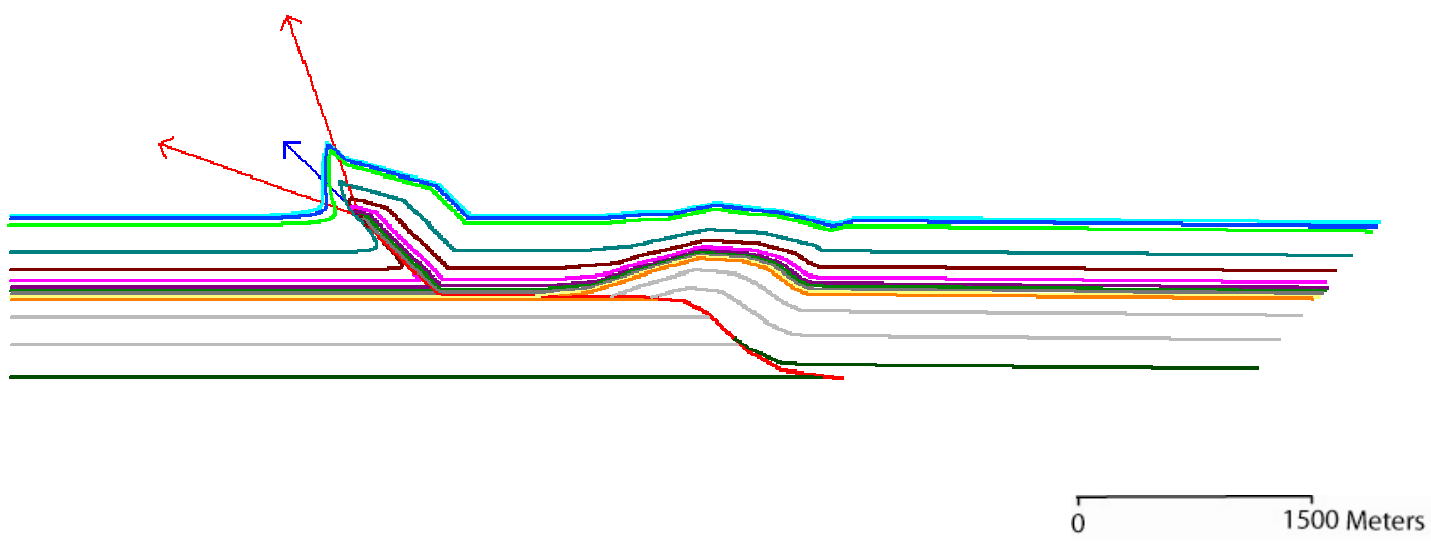

Figure 25: Diagram showing how a change in angular shear affects the geometry of the fold, all other variable remained constant. (a) Represents an angular shear of -45 . Notice how the beds have been pushed more from the top than the bottom. (b)

Represents and angular shear of 45 . Here the beds have been pushed more from the bottom than the top. 


\section{Footwall:}

To model the footwall of the St. Clair fault, the trishear algorithm within 2DMove was used. It was necessary to begin with a hand-drawn cross section based on observed field data (Figure 26a). Then the fault geometry was digitized and horizontal strata were drawn at the correct thicknesses (Figure 26b). Then the strata that are cut by the fault were split, making it possible to model the hanging wall and footwall separately (Figure 26c).

As noted previously, trishear deformation has been found to be responsible for the overturned footwall syncline, the Glen Lyn Syncline, of the St. Clair thrust fault. Trishear deformation has allowed for the changing of thicknesses as well as the rounded to angular fold shape. Several possibilities of combinations of parameters have led to similar final models, such as changing the apex angle, the number of trishear zones, and the trishear angle. As the ancestral St. Clair thrust fault began to propagate through the strata, the triangular zone in front of the fault tip began to deform the footwall strata. It has been determined through kinematic modeling that as the fault propagated through the strata, the trishear angle and the apex angle changed with time. Also, a small propagation- to-slip ratio was needed to produce the overturned syncline, as the fault did not reach the present day surface via trishear deformation. 
(a)

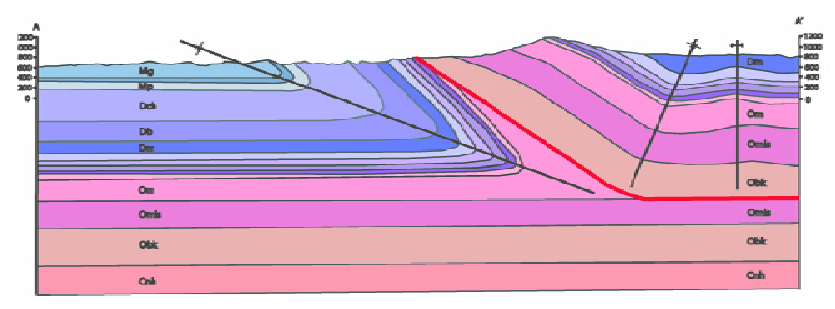

(b)

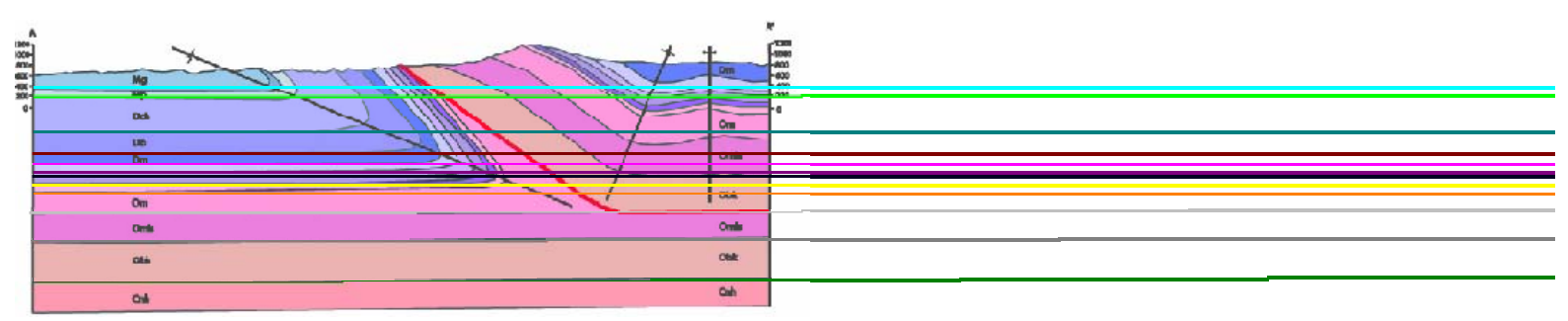

(c)

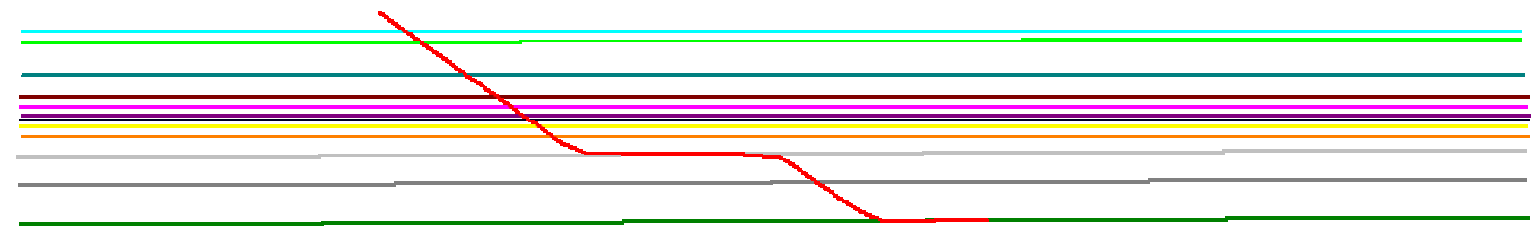

Figure 26: Beginning steps of kinematic modeling with 2DMove. (a) Is a hand-drawn cross section based on observed field data. (b) Represents $2^{\text {nd }}$ step in modeling. Horizontal layers are drawn at the correct thicknesses and the interpreted fault position is traced. (c) Is the final model to be used in 2DMove. Notice that all layers are horizontal. 
This combination of parameters created an overturned syncline with an angular fold (Figure 28a). A model of this type was necessary to deform horizontal layers into the correct geometry needed to reproduce the observed data. It has been found that for cross-section A-A', approximately 2000 meters of displacement was needed. It is believed that after the footwall was deformed, the strata were then slightly tilted in a southerly direction.

Other models were created, each differing slightly, but resulting in the same general geometry. These models each created an overturned syncline with a very angular fold. It is believed that in these models, splay faults near the beginning of the fault ramp were formed to accommodate folding and the stratigraphic changes in thickness. The stratigraphic thickness changes found with the kinematic modeling match very well with the observed field data.

The amount of deformation found in cross-section A-A' is not indicative of the total amount of deformation that occurred, as there is no evidence of a fold in the hanging wall. Therefore, the final 2 cross-sections were modeled using the same technique. These models provide a more precise value of deformation, as folding is evident in the hanging wall. As noted before, a step was incorporated into these final two models to allow for the older strata to appear in the footwall. For the second cross-section, B-B', a displacement value for the footwall ranged from 3300-3500 meters (Figure 27a). For the final cross-section, the displacement slightly decreased to a value of 2700-3150 meters (Figure 27b). 


\section{Hanging Wall:}

As the mode of deformation shifted from trishear towards fault-bend folding, the St. Clair thrust fault propagated through the remaining strata, due to an increase in the propagation-to-slip ratio. To model the hanging wall, the fault-parallel flow model in the 2DMove software package was used. The propagation of the fault through the strata allowed the hanging wall to be continually thrusted along the fault, without affecting the footwall. For the hanging wall, in cross-section A-A', to have been thrusted upon the footwall and to have placed the strata to its present day position, a minimum of 850 meters of displacement was needed (Figure 28b). As noted before, due to the lack of evidence of an anticline in the hanging wall, this value is the minimum amount of displacement that occurred. The values found for the two remaining cross-sections provide a more accurate displacement value, as an anticline is apparent in the hanging wall. A displacement value of 3200-4000 meters was found for cross-section B-B' and a value of 4000-5000 meters was found for cross-section C-C'.

There are several uncertainties within the hanging wall of the St. Clair thrust fault. These uncertainties arise from folding and faulting just south of the map area. It is believed that the Narrows thrust fault terminates just west of the study area, where faulting is transferred to folding. The exact location of the termination of the Narrows thrust fault is unknown, as it is either not exposed at the surface in the study area or it terminated prior to entering the study area. Previous models (Woodward, 1985) have suggested that the Narrows thrust fault transfers its deformation to folding just below the present day surface. Others have suggested that the Narrows thrust fault reaches the present day surface. 
Another uncertainty within the hanging wall is the geometry of the first ramp of the St. Clair thrust fault. It has been found that a ramp with a low angle is capable of reproducing the observed hanging wall geometry. Other possibilities include the presence of a duplex along the ramp, which could create a repetition of older strata, (Woodward, 1985) or a steeper ramp angle. The overturned anticline that was produced by the fault parallel flow in the hanging wall is not present in the study area. This is due to the extent of erosion the overturned anticline was subjected to. In the models produced, the final position of the overturned anticline was located above the present day topography, suggesting that it has been eroded away (Figure 28c). 
(a)

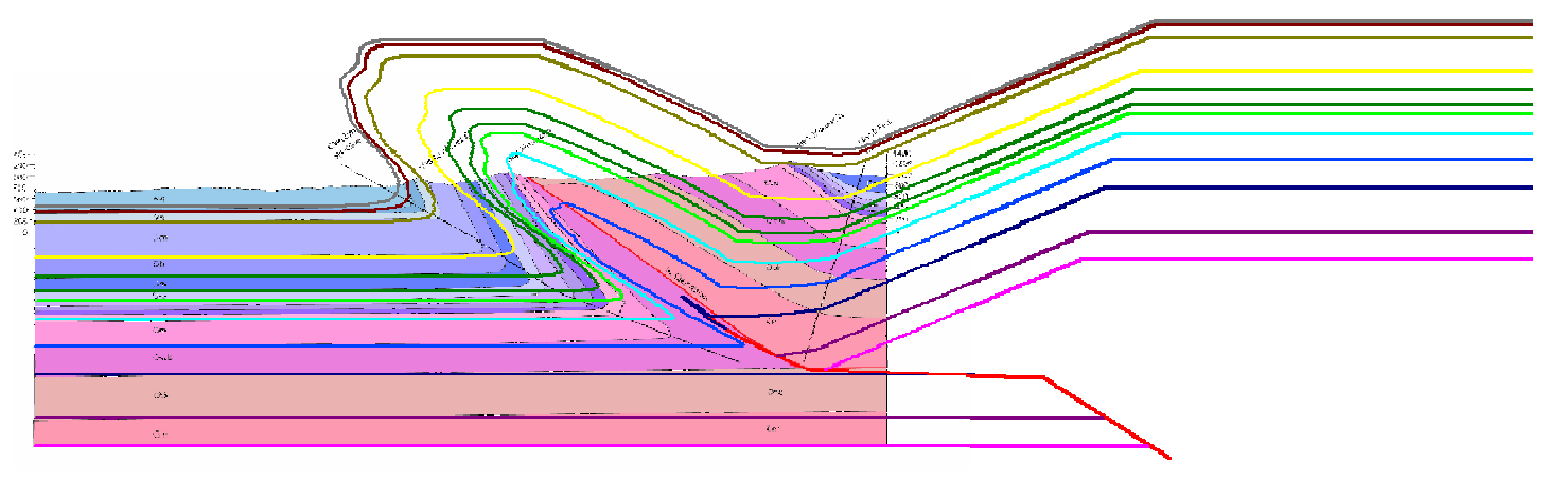

(b)

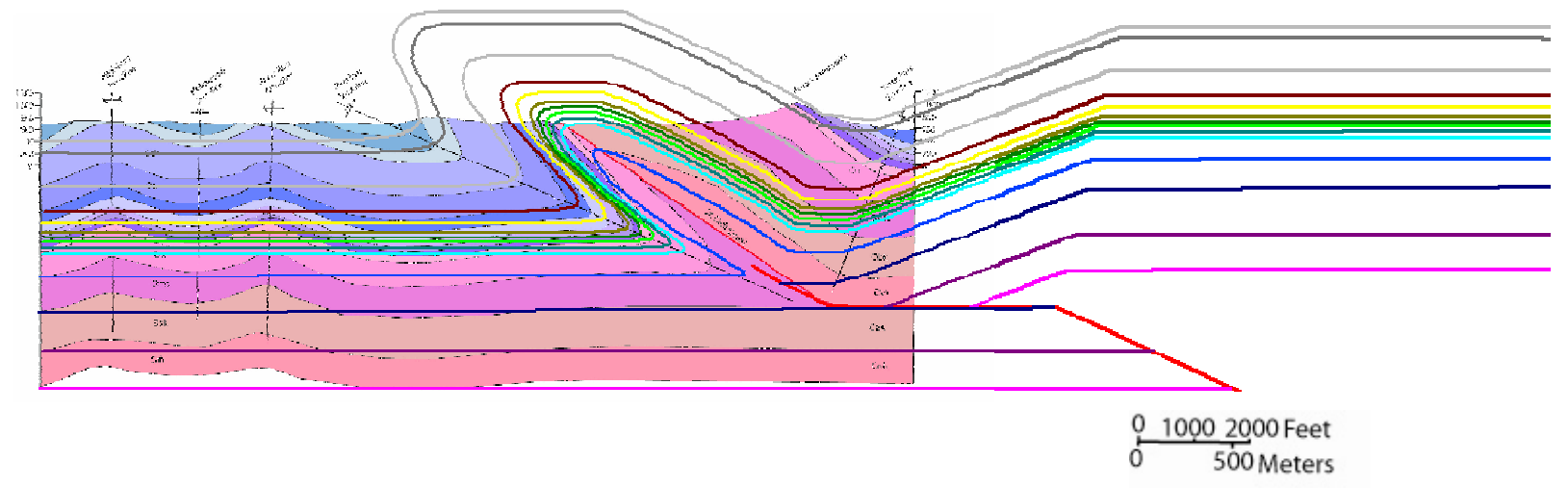

Figure 27: Cross-section B-B' and C-C' showing the step in the St. Clair thrust fault and the recreation of the footwall geometry. (a) Represents crosssection B-B' and (b) represents cross-section C-C'. 
(a)

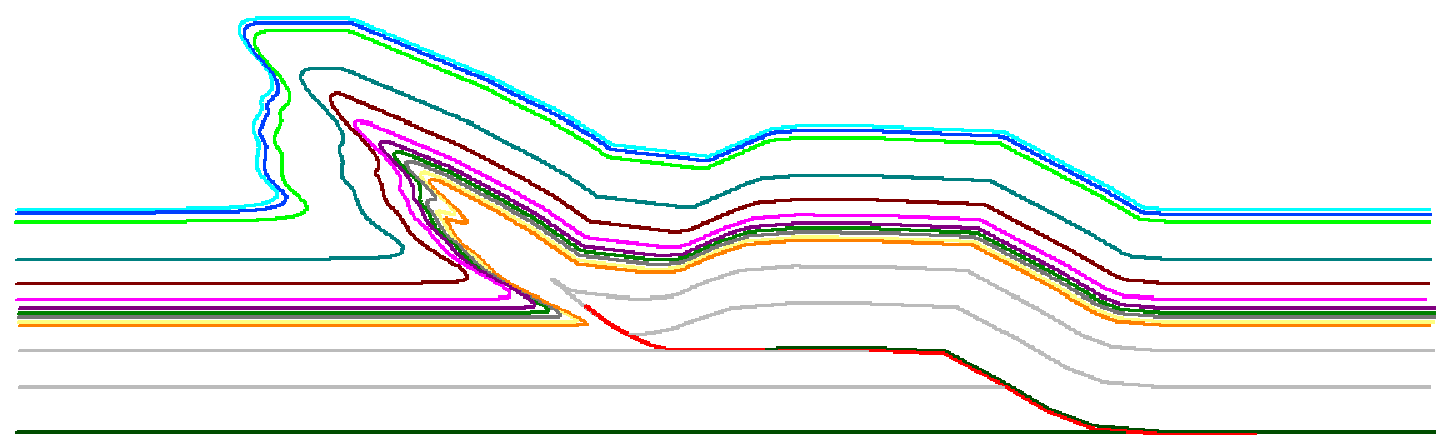

(b)

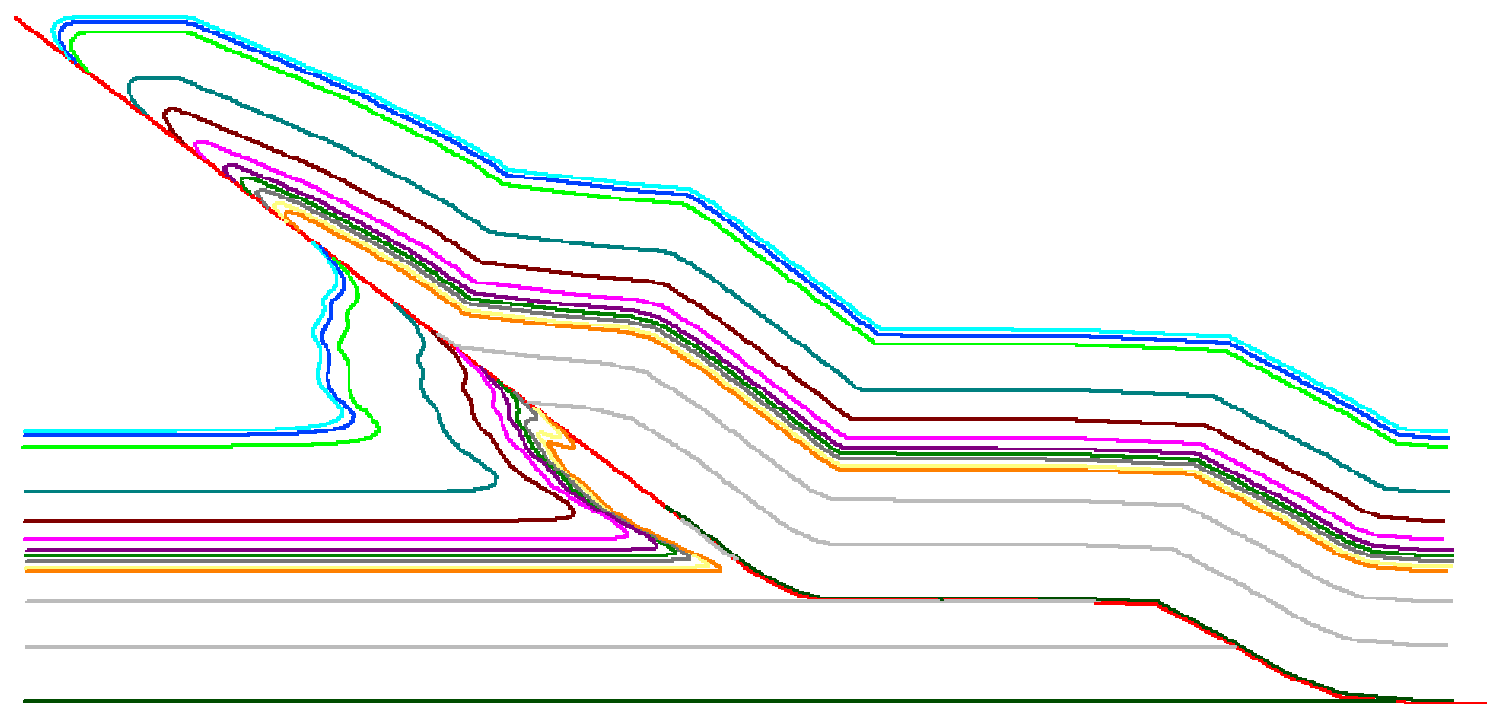

(c)

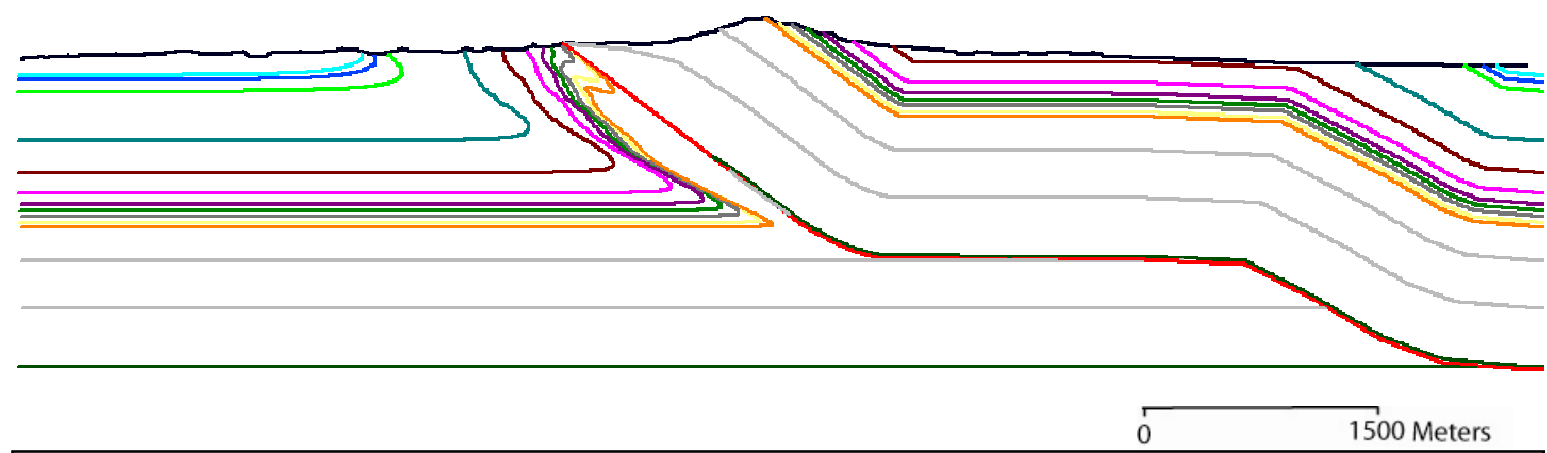

Figure 28: Diagram showing the evolution of the modeled cross-section A-A'. (a) Shows $1^{\text {st }}$ step in modeling, here the footwall has been recreated. (b) Shows the break-through of the fault and the continued thrusting of the hanging wall. (c) Shows the final stage in modeling, with present-day topography shown. 


\section{Chapter 8: Conclusions and Further Studies}

1. The St. Clair thrust fault trends in a southwest to northeast direction through the map area, terminating just east of the West Virginia-Virginia border, in Allegheny County, Virginia. The hanging wall within the study area is comprised of the Late CambrianEarly Ordovician Knox Group through the Devonian Marcellus Series. The footwall of the St. Clair thrust is comprised of the Middle Ordovician Limestone to the Middle Mississippian Greenbrier Limestone and the Late Mississippian Mauch Chunk Group. The St. Clair thrust fault terminates within the core of the Wills Mountain Anticline (Spraggins and Dunne, 2002).

2. The St. Clair thrust fault formed as a combination of trishear deformation and faultbend folding. The overturned footwall syncline was formed by trishear deformation as the fault slowly propagated though the strata. The hanging wall was then thrusted upon the footwall as the propagation-to-slip ratio increased and the mode of deformation switched from trishear to fault-bend folding and the fault broke through to the surface.

3. By recreating the sequential cross-sections, it was possible to determine the amount of displacement needed for each cross-section. Cross-section A-A' was modeled and a displacement value of approximately 2300 meters was needed. This value is of less 
significance as it represents the minimum amount of displacement needed as there if no evidence of an anticline in the hanging wall.

4. Two additional cross-sections were modeled, each that show evidence of an anticline in the hanging wall. The values of deformation in these cross-sections are more representative of the actual amount of displacement needed. Cross-section B-B' had a total displacement value of approximately 7500 meters and C-C' had a value of approximately 6700 meters.

5. Cross-sections B-B' and C-C' show evidence that the displacement value is decreasing to the northeast. A decrease in displacement of 800 meters was found, or 10.66 percent.

6. Using R.W. Allmendinger's trishear modeling program, Fault/Fold, it has been possible to estimate the strain within the trishear triangle zone (Allmendinger, 1998: and Zehnder and Allmendinger, 2000). Through kinematic modeling it has been determined that during the initial trishear deformation, the St. Clair thrust had a small propagation-to-slip ratio before the mode of deformation shifted to fault-bend folding. This small P:S ratio suggests that the strata in the footwall underwent more strain than if the P:S ratio was larger.

7. Areas where intense trishear deformation has occurred, and hence have undergone significant strain, could be possible areas of intense fracturing. These areas of intense 
fracturing are possible targets for natural gas production. One possible location within the study area is in the overturned footwall of the St. Clair thrust fault and between the Glen Lyn and Hurricane Ridge Synclines, where the Marcellus Series is present.

Possibilities for additional research include:

1. The acquisition of seismic reflection data to aid in the interpretation of the overturned footwall syncline and to better constrain the thicknesses of the strata. In addition, this would allow for a more precise location of the St. Clair thrust fault itself and a better understanding of the fault geometry.

2. Additional studies to the south would indicate the effect of other geologic structures. Areas of interest could be: what are the effects of the Narrows thrust fault, the Saltville thrust fault, or any of the other structures on the geometry of the St. Clair thrust fault. 


\section{References}

Allmendinger, R. W., 1998, Inverse and Forward Numerical Modeling of Trishear FaultPropagation Folds: Tectonics, v. 17, no. 4, p. 640-656.

Allmendinger, R.W., Zapata, T., Manceda, R., and Dzelalija, F., 2004, Trishear Kinematic Modeling of Structures, with Examples from the Neuquén Basin, Argentina, in K.R. McClay, ed., Thrust tectonics and hydrocarbon systems: AAPG Memoir 82, p. 356371.

Bjerstedt, T.W., 1986, Stratigraphy and deltaic depositional systems of the Price Formation (Upper Devonian-Lower Mississippian) in West Virginia, Unpublished Dissertation, West Virginia University, Morgantown, West Virginia 730 p.

Bjerstedt, T.W., and Kammer, T.W., 1988, Genetic stratigraphy and depositional systems of the Upper Devonian-Lower Mississippian Price-Rockwell deltaic complex in the central Appalachians, U.S.A.: Sedimentary Geology, v. 54, p. 265-301.

Butts, C., 1918, Geologic Section of Blair and Huntington Counties, Central

Pennsylvania: American Journal of Science, ser. 4, v. 46, p. 523-537

Campbell, M.R., 1895, Paleozoic Overlaps in Montgomery and Pulaski Counties, Virginia, Geological Society of America Bulletin, v. 5, p. 171-190.

Cardozo, N., Bhalla, V., Zehnder, A.T., and Allmendinger, R,W., 2003, Mechanical models of fault propagation folds and comparison to the trishear kinematic model, Journal of Structural Geology, v. 25, issue 1, p. 1-18.

Cardwell, D.H., Erwin, R.B., and Woodward, H., 1968, Geological Map of West Virginia, Scale 1:250,000, West Virginia Geological and Economic Survey.

Cooper, B.N., 1961, Grand Appalachian Excursion, Virginia Polytechnic Institute Engineering Extension Series, Geological Guidebook 1.

Couzens, B.A., and Dunne, W.M., 1994, Displacement transfer at thrust terminations: the Saltville thrust and Sinking Creek anticline, Virginia, USA, Journal of Structural Geology 16, p. 781-793.

Dahlstrom, C.D.A., 1969, Balanced Cross Sections: Canadian Journal of Earth Sciences, v. 6, p. 743-757.

Darton, N.H., and Taff, J.A., 1896, Piedmont, West Virginia - Maryland, folio 28 of Geologic Atlas of the United States, U.S. Geological Survey. 
Dean, S.L., Kulander, B.R., and Williams, R.E., 1979, Regional Tectonics, Systematic Fractures and Photolinears in Southeastern West Virginia, Proceedings of the International Conference on Basement Tectonics, issue 2, p 10-51.

Dean, S.L., Kulander, B.R., and Skinner, J.M., 1988, Structural Chronology of the Alleghenian Orogeny in Southeastern West Virginia: Geological Society of America Bulletin, v. 100, p. 299-310.

Durham, L.S., 2008, Appalachian Basin's Marcellus - New Target: Another Shale Making Seismic Waves, American Association of Petroleum Geologists Explorer, v. 29, no. 3, p. 6-10.

Erslev, E.A., 1991, Trishear Fault-Propagation Folding: Geology, v. 19, p. 617-620.

Geiger, H.R. and Keith, A., 1891, The Structure of the Blue Ridge near Harpers Ferry, Maryland-West Virginia, Geological Society of America Bulletin, v. 2, p. 161.

Giffels, M.N., 2002, Kinematics of Detachment folding, Appalachian Valley and Ridge, West Virginia, Masters Thesis, West Virginia University, Morgantown, West Virginia.

Gustafson, T.K., 1982, Geology and Structural Analysis between the Narrows and St. Clair Thrust Faults in the Narrows Quadrangle, Giles County, Virginia: Master's Thesis, Eastern Kentucky University.

Hardy, S., and Ford, M., 1997, Numerical Modeling of Trishear Fault-Propagation Folding and Associated Growth Strata: Tectonics, v. 16, p. 841-854.

Johnson, K.M., Johnson, A.M., 2002, Mechanical Models of Trishear-Like Folds, Journal of Structural Geology, v. 25, p. 277-287.

Johnson, S.R., 2007, Surface and Subsurface Fault and Fracture Systems with Associated Natural Gas Production in the Lower Mississippian and Upper Devonian, Price Formation, Southern West Virginia, Master's Thesis, West Virginia University, Morgantown, West Virginia, 102p.

Kammer, T.W., 2001, Generalized Stratigraphy of Southeastern West Virginia, Unpublished paper, for use in WVU Field Camp.

Kattenhorn, S.A., 1994, Outcrop-Scale Fault-Related Folds, Valley and Ridge Province, Appalachians: Comparison to Kinematic Model Predictions, Master's Thesis, The University of Akron, Akron, Ohio.

Kreisa, R.D., 1980, The Martinsburg Formation (Middle and Upper Devonian) and Related Facies in Southwest Virginia, Virginia Polytechnic Institute and State University, unpublished Ph.D. thesis. 
Kulander, B.R., and Dean, S.L., 1986, Structure and tectonics of Central and Southern Appalachian Valley and Ridge and Plateau provinces, West Virginia and Virginia: American Association of Petroleum Geologists Bulletin, v. 70, p. 1674-1684.

Kulander, B.R., 1987, Structural style and tectonics of the central and southern Appalachians: West Virginia Geologic and Economic Survey Circular, v. 40, p. 55.

Kulander, B.R., and Dean, S.L., 1988, The North Mountain-Pulaski Fault System and Related Thrust Sheet Structure: Geological Society of America, Special Paper 222, p. 107-118.

Lesley, J.P., 1876, Historical Sketch of Geological Explorations in Pennsylvania and Other States, Pennsylvania Geological Survey Report 2, p. 221-222.

McClay, K., 1998, Thrust Systems IV - Fault Related Folding: Structural Geology for Petroleum Exploration, p. 321-351.

McDowell, R.C., and Schultz, A.P., 1989, Structural and Stratigraphic Framework of the Giles County Area, a Part of the Appalachian Basin of Virginia and West Virginia: United States Geological Survey Bulletin 1839, Evolution of Sedimentary Basins Appalachian Basin, p. E1-E24.

McGuire, O.S., 1970, Geology of the Eagle Rock, Strom, Oriskany, and Salisbury Quadrangles, Virginia, Virginia Division of Mineral Resources Report of Investigations $24,39 \mathrm{p}$.

Mehlhop, A.L., 1996, Extensional Structures along the Allegheny Front in Virginia and West Virginia near the Giles County Seismic Zone: Master's Thesis, University of North Carolina at Chapel Hill.

Midland Valley Help Files, Midland Valley Ltd., 14 Park Circus, Glasgow G3 6AX, United Kingdom, 217 p.

Mitra, S. and Fisher, G.W., 1992, Balanced Structural Interpretations in Fold and Thrust Belts: "Structural Geology of Fold and Thrust Belts, p. 53-77.

Price, P.H., 1929, Pocahontas County, West Virginia Geological Survey County Reports.

Reger, D.B., and Price, P.H., 1926, Mercer, Monroe, and Summers Counties, West Virginia Geological Survey County Report, Wheeling News Lithograph Company, Wheeling, WV, $963 \mathrm{p}$.

Safford, J.M., 1869, Geology of Tennessee, Nashville, Tennessee. 
Shumaker, R., 1996, Structural history of the Appalachian Basin, in Roan, J.B., and Walker, B.J., eds., The Atlas of Major Appalachian Gas Plays, West Virginia Geological and Economic Survey Publication V. 25, 201 p.

Spraggins, S.A., and Dunne, W.M., 2002, Deformation History of the Roanoke Recess, Appalachians, USA, Journal of Structural Geology 24, p. 411-433.

Stanley, C.B., 1983, Kinematic Implications of Footwall Structures: Master's Thesis, Virginia Polytechnic Institute and State University, Blacksburg, Virginia.

Stose, G.W., 1913, Geology of the Salt and Gypsum Deposits of Southwestern Virginia, U.S. Geological Survey Bulletin 23.

Suppe, J. and Medwedeff, D.A., 1984, Geometry and Kinematics of Fault-Propagation Folding: p. 409-454.

Suppe, J., 1985, Principles of structural geology: Englewood Cliffs, New Jersey, Prentice-Hall, 537 p.

Swartz, C.K., 1923, Silurian, Baltimore, Maryland Geological Survey. 794 p.

Ulrich, E.O., 1911, Revision of Paleozoic Formations, Geological Society of America Bulletin, v. 22, no. 3, p. 281-680.

Walker, J. D., and Cohen, H.A., 2006, The Geoscience Handbook, AGI Data Sheets, Fourth Edition. P. 41.

Wiltschko, D.V., and W.M. Chapple, 1977, Flow of weak rocks in Appalachian Plateau folds: AAPG Bulletin, v. 61, p. 653-670.

Woodward, N.B., 1985, Valley and Ridge Thrust Belt: Balanced Structural Sections, Pennsylvania to Alabama: Appalachian Basin Industrial Associates, University of Tennessee Department of Geological Sciences, Studies in Geology 12, p 36-41.

WVGES, 2006, West Virginia Geology: Historical Geology Summary, http://www.wvgs.wvnet.edu/www/geology/geolhist.htm

Zehnder, A. T., and Allmendinger, R. W., 2000, Velocity Field for the Trishear Model: Journal of Structural Geology, v. 22, p. 1009-1014. 


\section{Appendix I: Field observations}

के

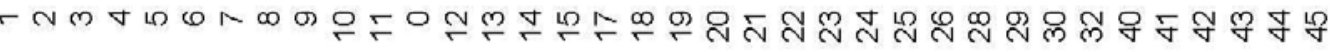

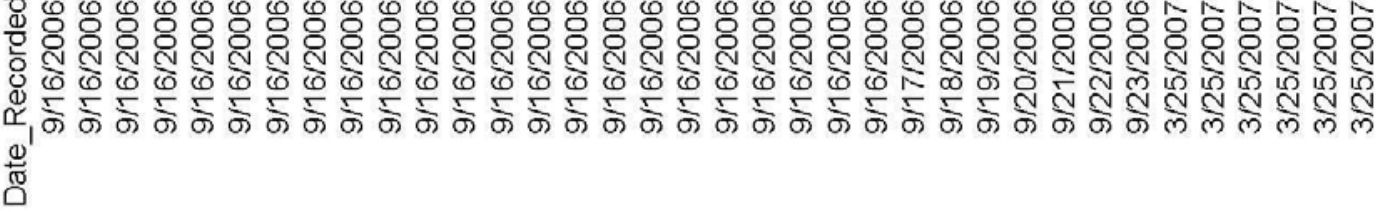

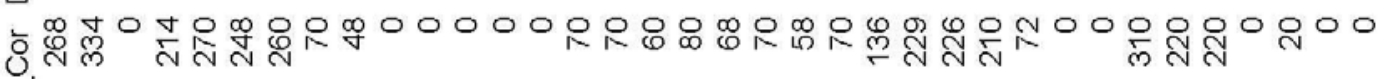
突

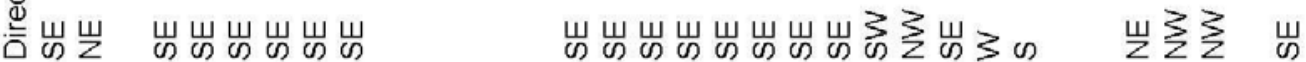

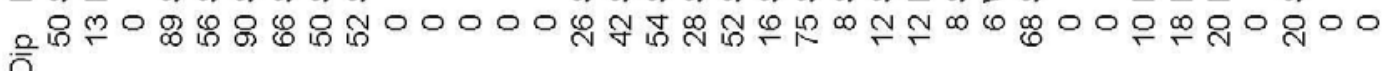
乐药 致

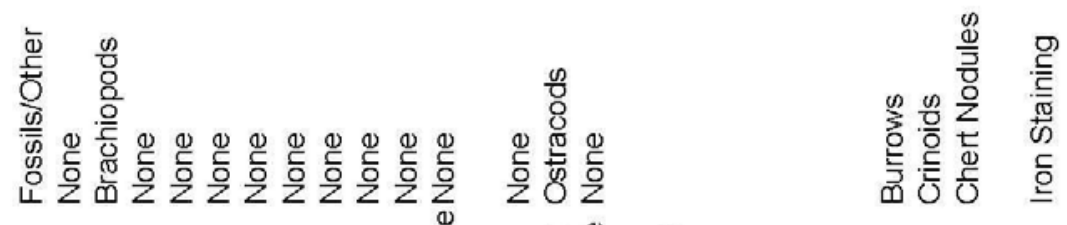

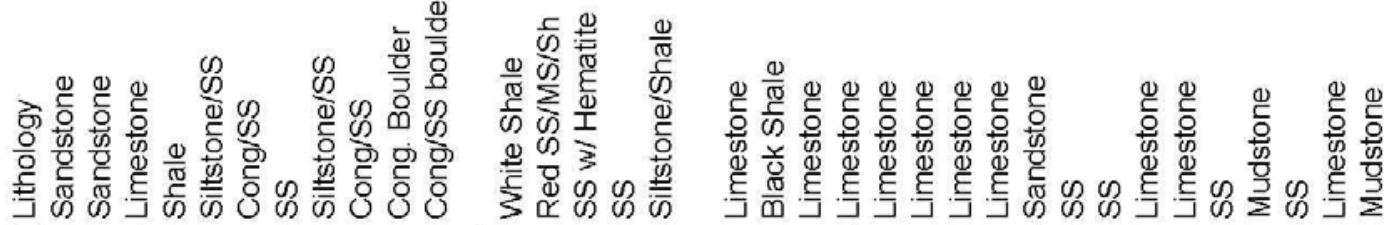

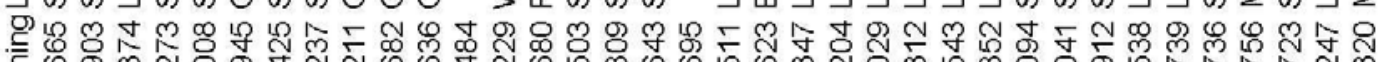
至品品

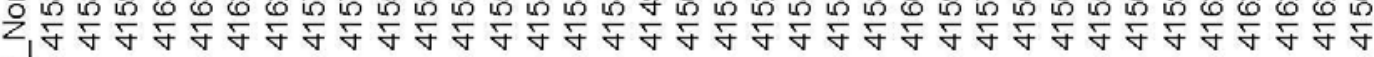
高

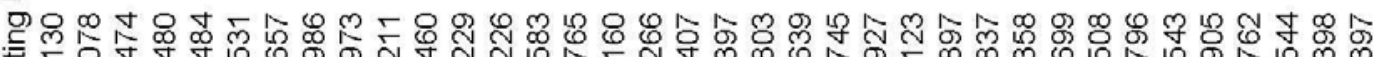

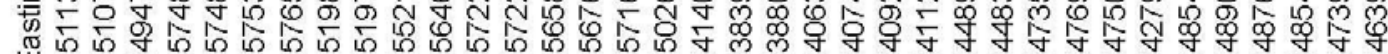

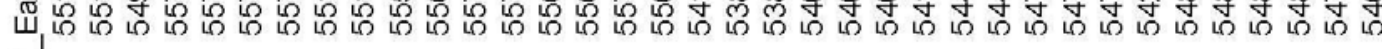
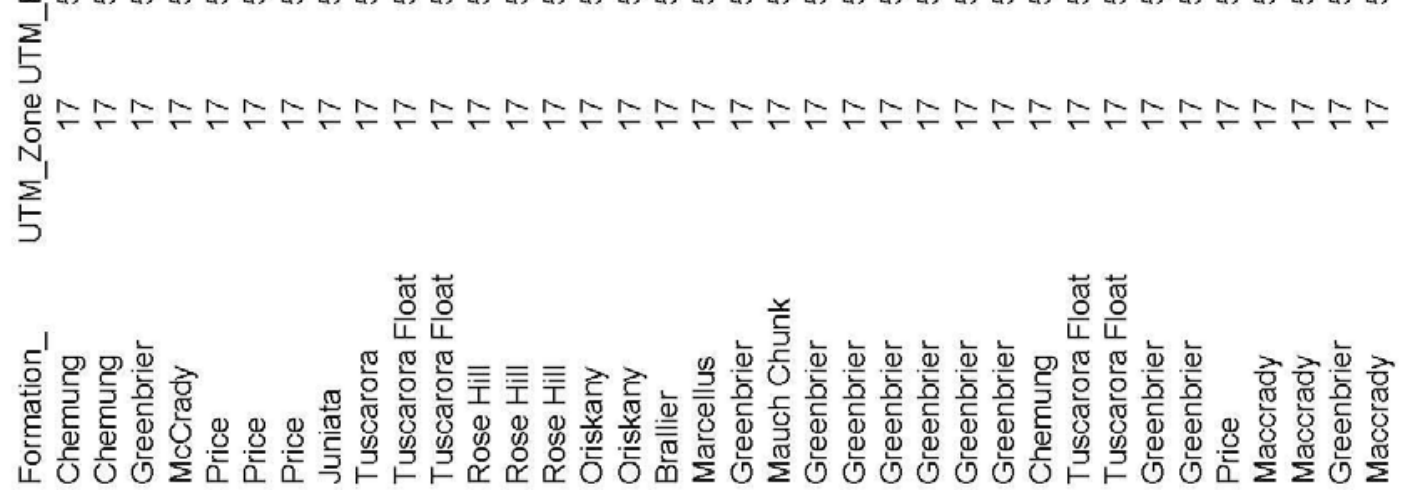
Appendix I: Field observations, continued

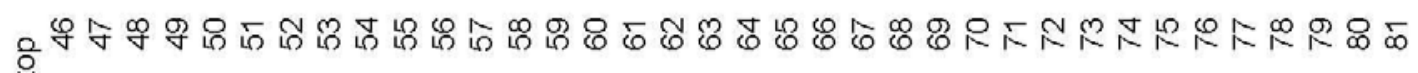
के

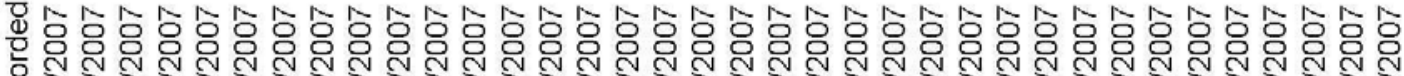
告

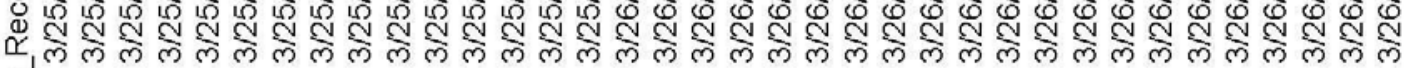
这

i

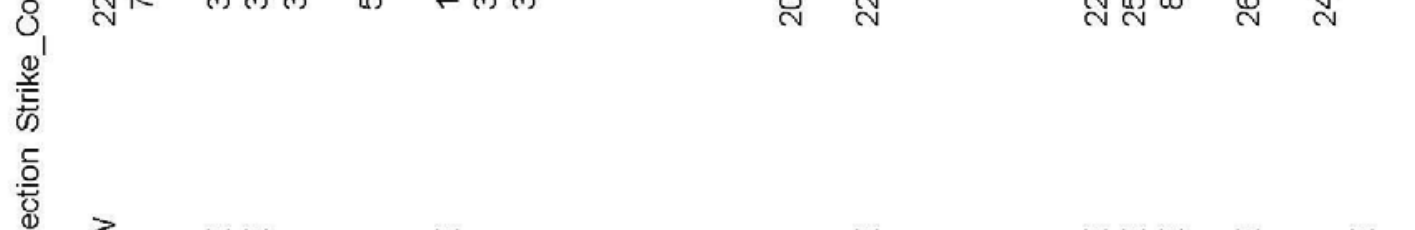

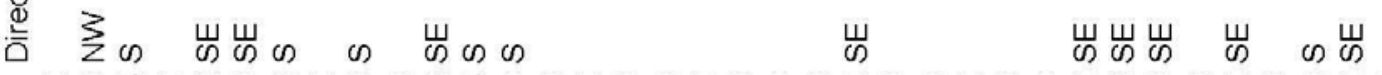

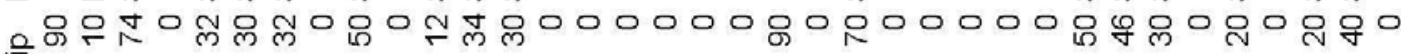
六

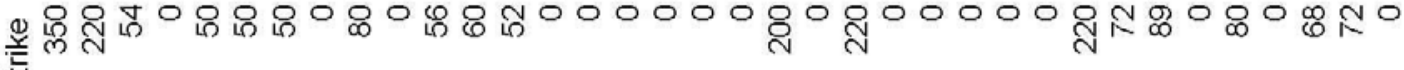
क

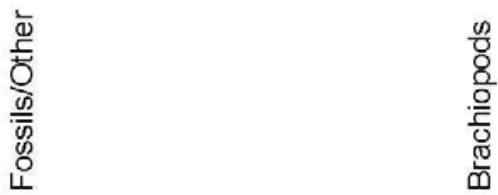

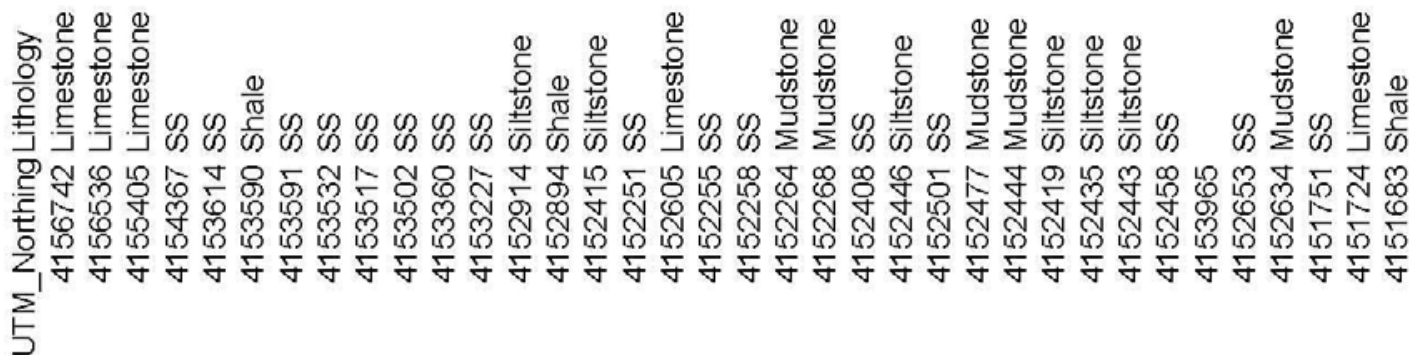

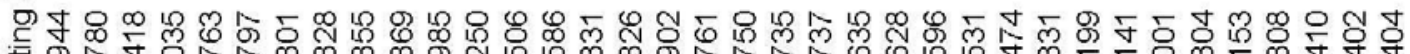

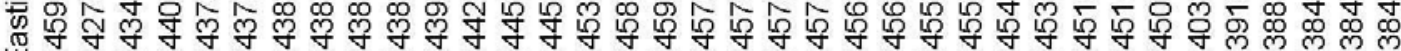

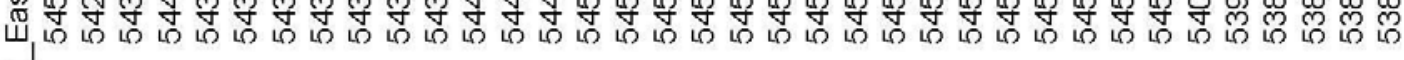
$\Sigma$

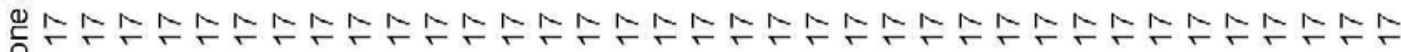
N

$\sum_{5}^{1}$

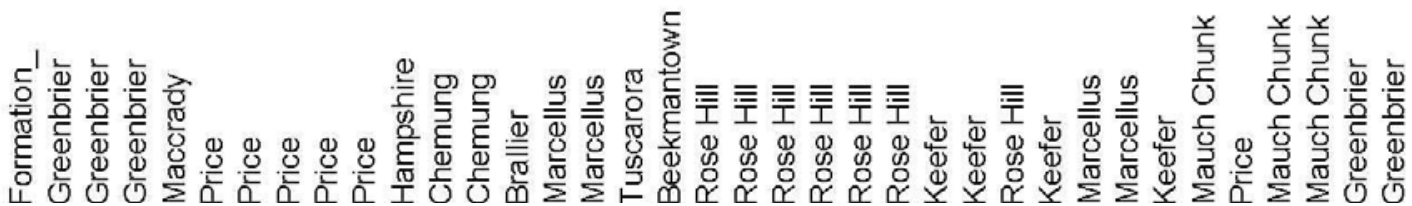


Appendix I: Field observations, continued

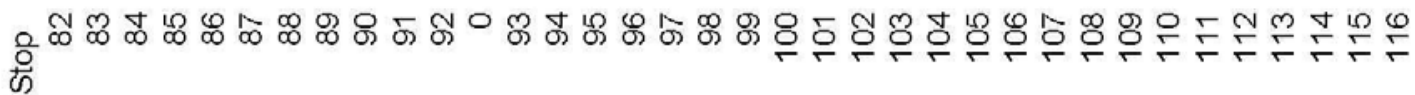

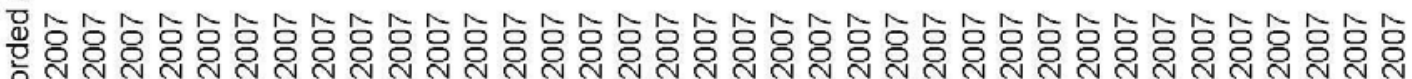

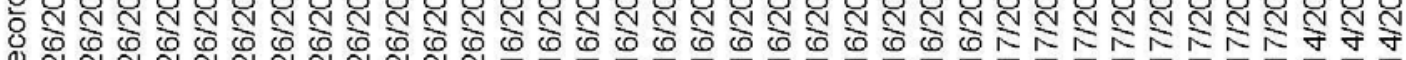
虫 $\stackrel{\stackrel{ \pm}{\mathbb{D}}}{\Delta}$

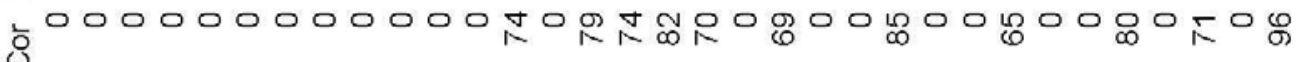

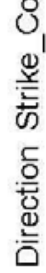

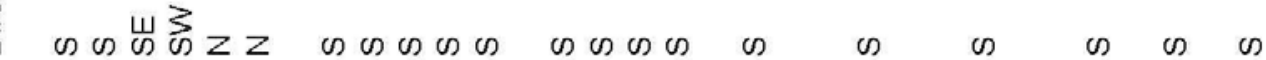

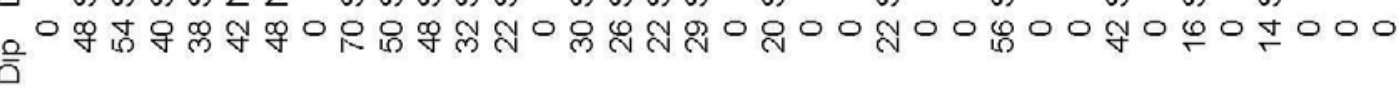
m 亮

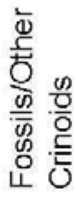
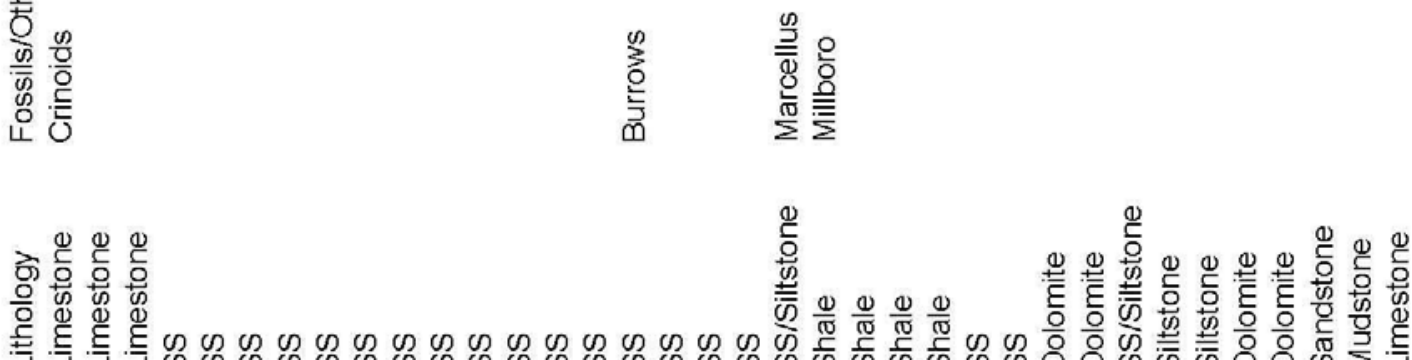
ヨ.

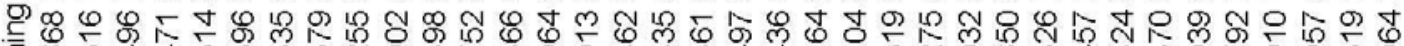

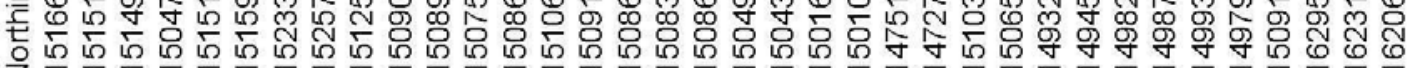

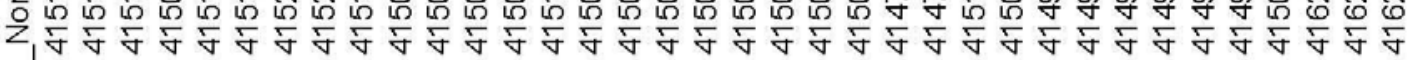

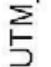

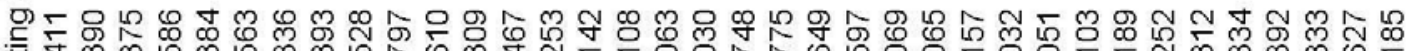
焉

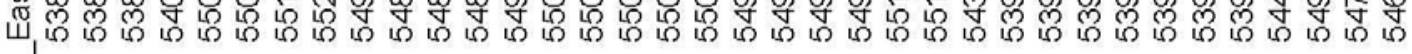

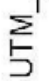

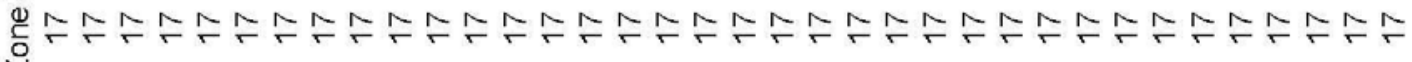
N

号

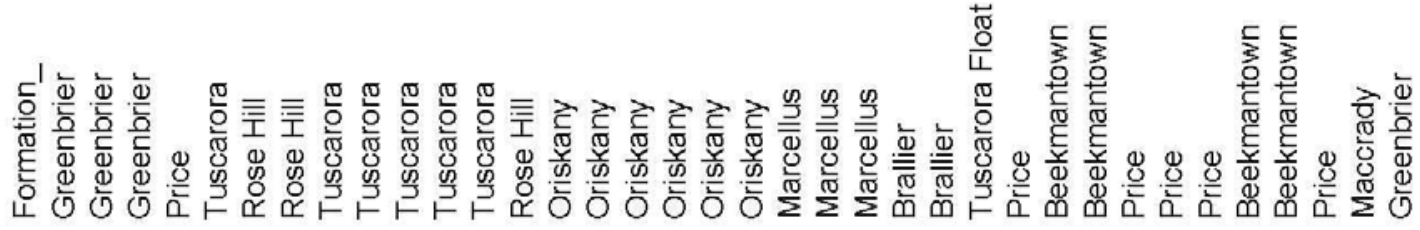


Appendix I: Field observations, continued

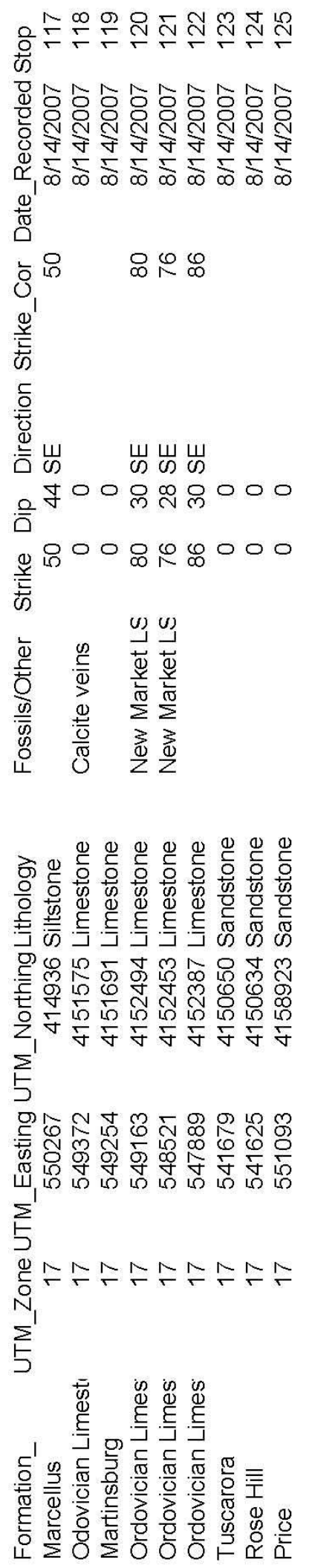




\section{Appendix II: CMYK Values used for geologic mapping}

\begin{tabular}{|l|l|}
\hline Formation & CMYK Values \\
\hline Mmch & $32 \mathrm{~A} 0$ \\
\hline $\mathrm{Mg}$ & $42 \mathrm{~A} 0$ \\
\hline $\mathrm{Mmcc}$ & 5310 \\
\hline $\mathrm{Mp}$ & $21 \mathrm{~A} 0$ \\
\hline $\mathrm{Dch}$ & 3300 \\
\hline $\mathrm{Db}$ & 4400 \\
\hline $\mathrm{Dm}$ & 6500 \\
\hline $\mathrm{Drg}$ & 2200 \\
\hline $\mathrm{Sk}$ & 2300 \\
\hline Srh & $34 \mathrm{~A} 0$ \\
\hline $\mathrm{St}$ & 4600 \\
\hline Oj & 0310 \\
\hline Om & 0410 \\
\hline Omls & A510 \\
\hline Obk & A330 \\
\hline Cnh & 0430 \\
\hline
\end{tabular}

\begin{tabular}{|l|l|l|l|l|l|l|l|l|}
\hline $\mathrm{A}=8 \%$ & $1=13 \%$ & $2=20 \%$ & $3=30 \%$ & $4=40 \%$ & $5=50 \%$ & $6=60 \%$ & $7=70 \%$ & $\mathrm{X}=100 \%$ \\
\hline
\end{tabular}




\section{Appendix III: Regional Changes in Nomenclature}

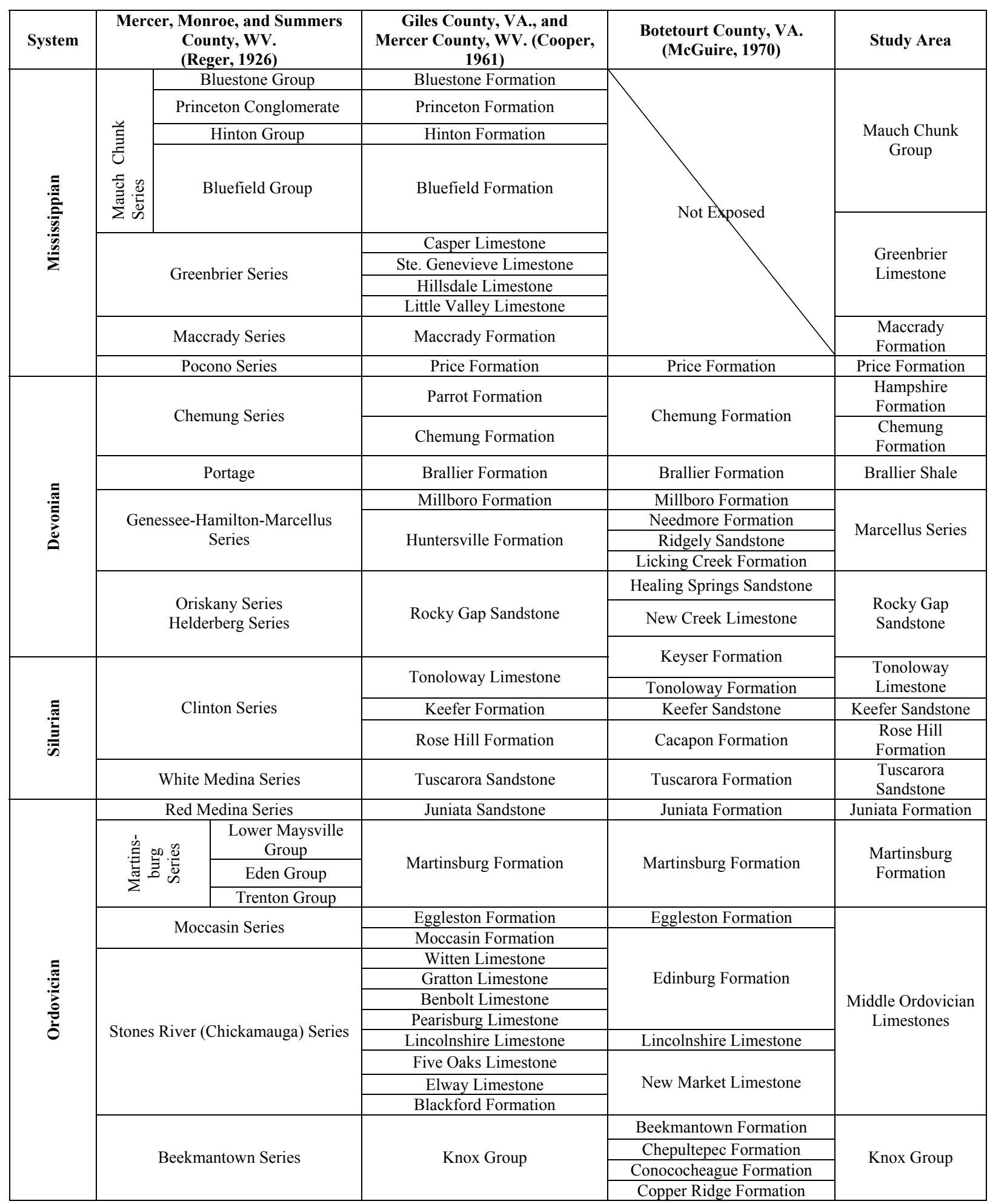

-Modified from McDowell and Schultz, 1989 